PNL-4563 1 -

NUREG/CR-3087 PNL-4563

\title{
Incineration of a
} Typical LWR Combustible Waste and Analysis of the Resulting Ash

Prepared by R. L. Treat, R. O. Lokken, M. J. Schliebe

Pacific Northwest Laboratory

Operated by

Battelle Memorial Institute

Prepared for

U.S. Nuclear Regulatory

Commission 


\section{NOTICE}

This report was prepared as an account of work sponsored by an agency of the United States Government. Neither the United States Government nor any agency thereof, or any of their employees, makes any warranty, expressed or implied, or assumes any legal liability of responsibility for any third party's use, or the results of such use, of any information, apparatus, product or process disclosed in this report, or represents that its use by such third party would not infringe privately owned rights.

\section{Availability of Reference Materials Cited in NRC Publications}

Most documents cited in NRC publications will be available from one of the following sources:

1. The NRC Public Document Room, 1717 H Street, N.W. Washington, DC 20555

2. The NRC/GPO Sales Program, U.S. Nuclear Regulatory Commission, Washington, DC 20555

3. The National Technical Information Service, Springfield, VA 22161

Although the listing that follows represents the majority of documents cited in NAC publications, it is not intended to be exhaustive.

Referenced documents available for inspection and copying for a fee from the NRC Public Document Room include NRC correspondence and iriternal NRC memoranda; NRC Office of Inspection and Enforcement bulletins, circulars, information notices, inspection and investigation notices; Licensee Event Reports; vendor reports and correspondence; Commission papers; and applicant and licensee documents and correspondence.

The following documents in the NUREG series are available for purchase from the NAC/GPO Sales Program: formal NRC staff and contractor reports, NRC-sponsored conference proceedings, and NRC booklets and brochures. Also available are Regulatory Guides, NRC regulations in the Code of Federal Regulations, and Nuclear Regulatory Commission Issuances.

Documents available from the National Technical Information Service include NUREG series reports and technical reports prepared by other federal agencies and reports prepared by the Atomic Energy Commission, forerunner agency to the Nuclear Regulatory Commission.

Documents available from public and special technical libraries include all open literature items, such as books, journal and periodical articles, and transactions. Federal Register notices, federal and state legislation, and congressional reports can usually be obtained from these libraries.

Documents such as theses, dissertations, foreign reports and translations, and non-NRC conference proceedings are available for purchase from the organization sponsoring the publication cited.

Single copies of NRC draft reports are available free upon written request to the Division of Technical Information and Document Control, U.S. Nuclear Regulatory Commission, Washington, DC 20555

Copies of industry codes and standards used in a substantive manner in the NRC regulatory process are maintained at the NRC Library, 7920 Norfolk Avenue, Bethesda, Maryland, and are available there for reference use by the public. Codes and standards are usually copyrighted and may be purchased from the originating organization or, if they are American National Standards, from the American National Standards Institute, 1430 Broadway, New York, NY 10018. 
NUREG/CR-3087

PNL-4563

RW

Incineration of a

Typical LWR Combustible Waste and Analysis of the Resulting Ash

Manuscript Completed: February 1983

Date Published: May 1983

Prepared by

R. L. Treat, R. O. Lokken, M. J. Schliebe

Pacific Northwest Laboratory

Richland, WA 99352

Prepared for

Division of Health, Siting and Waste Management

Office of Nuclear Regulatory Research

U.S. Nuclear Regulatory Commission

Washington, D.C. 20555

NRC FIN B2401 



\section{ABSTRACT}

In this study $4540 \mathrm{~kg}(10,000 \mathrm{lb})$ of simulated nuclear power plant combustible wastes were burned in a controlled-air incinerator. The purpose of this work was to generate ashes suitable for solidification, the products of which will be analyzed to determine if they are suitable for disposal. Two different types of waste were burned: resins and simulated crud, and general trash (paper, plastics, wood, rubber, and cloth). Volume-reduction ratios (unburned waste: ash) were 13:1 and 22:1, respectively. Approximately $20 \%$ of the ash was lost due to adherence to incinerator walls and entrainment in the off-gas stream. Losses of the volatile species cesium and iodine were $79 \%$ and $100 \%$, respectively. The ashes were not hygroscopic, but they exhibited a pH of 4.6 to 5.0 when water was added. Corrosion of mild steel drums would occur within this $\mathrm{pH}$ range. The ashes contained a significant quantity of clinkers having lengths as great as $20 \mathrm{~cm}$ ( $8 \mathrm{in.)}$. Most of the clinkers were fully incinerated and easy to crush, suggesting that standard comminuting equipment should be effective in reducing the size of clinkers to allow their solidification with the fine ashes. 



\section{CONTENTS}

ABSTKACT

EXECUTIVE SUMMARY......................................

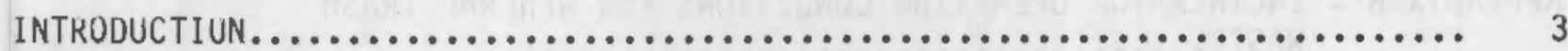

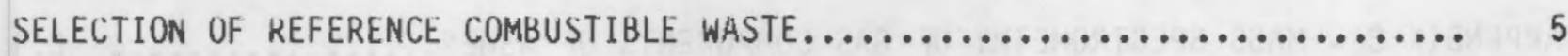

WASTE PACKAGING....................................... 7

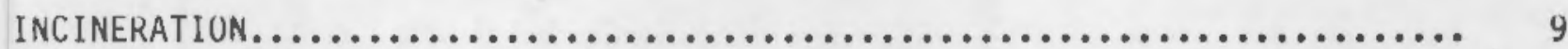

BURN NO. 1 , RESIN WASTE............................. 10

BURN N0. 2, TRASH WASTE............................ 10

DISCUSSION OF INCINERATION RESULTS...................... 10

ASH CHARACTERIZATIUN...................................... 13

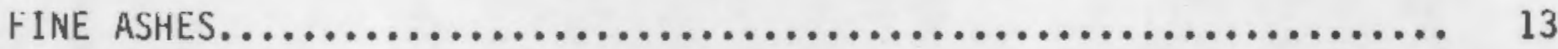

X-Kay Diffraction................................. 13

BET Surface Area................................. 13

Thermoyravimetric Analysis-Differential Thermal Analysis....... 14 Quadrupole Mass Spectronetry......................... 14

Scanning Electron Microscopy/Energy Dispersive

Analysis by $\mathrm{X}$-Kay....................................... 14

Chemical Analysis by Inductively Coupled Plasma

Emission Spectrometry................................ 15

ASH CLINKERS........................................ 24

Appearance....................................... 24

Density.......................................... 25

Calcination...................................... 26

Friability...................................... 26

Leaching........................................ 27 
DISCUSSION OF ASH CHARACTERIZATION RESULTS.............. 28

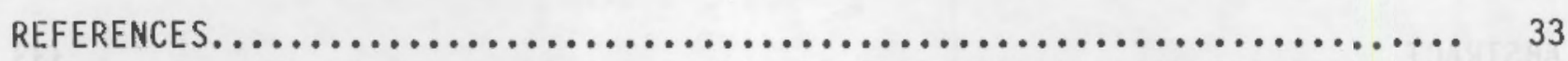

APPENDIX A - INCINERATOR DPERATING CONDITIONS FOR RESIN WASTE.......... A. 1

APPENDIX B - INCINERATOR OPERATING CONDITIONS FOR GENERAL TRASH WASTE.......................................

APPENDIX $C$ - MASS SPECTROMETRY OF GAS COMPONENTS OF ASHES............ C.1 


\section{FIGURES}

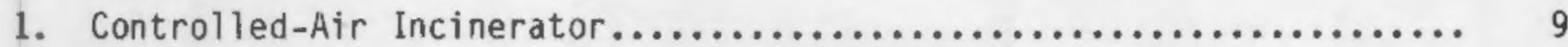

2. TGA Weight Loss of Resin Ash and Trash Ash Heated

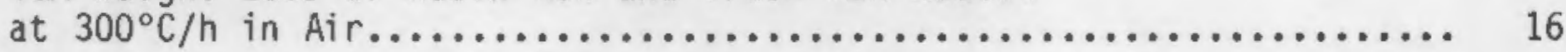

3. SEM Micrographs of Typical Trash Ash Particles.................. 17

4. EDAX Spectra of Trash Ash Particles Seen in

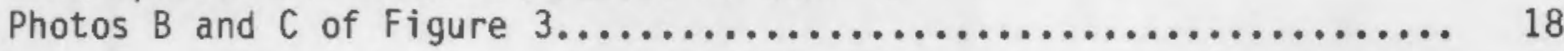

5. SEM Micrographs of Resin Ash Particles A and B.................. 19

6. SEM Micrographs of Resin Ash Particles $C$ and D.................. 20

7. SEM Micrographs of a Resin Ash Particle Showing Adhered Crystals............................................ 21

8. EDAX Spectra of a Typical Resin Ash Particle.................... 22

9. Typical Large Ash Clinkers................................ 25

10. Types of Clinkers Used for Density Measurements................. 25

11. Individual Clinkers Subjected to Static, $90^{\circ} \mathrm{C}$ Leach Tests.......... 27

\section{TABLES}

1. Components of Combustible LLW............................... 5

2. Reference LWR Combustible LLW.............................. 6

3. Combustible Waste Spiking Solutions......................... 8

4. Dxide Composition of As-Received and Calcined Trash Ash, Resin Ash, and Ball-Milled Blended Ash Determined by ICP and AA Analysis.......................................... 23

5. Percent of Spiking Chemicals Recovered........................ 24

6. Clinker Weight Loss After Calcination......................... 26

7. Leachate $\mathrm{pH}$ Values After Leaching Various Ash Clinkers

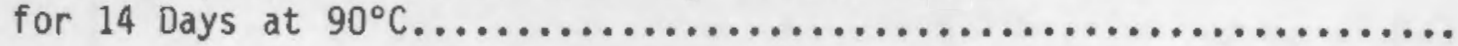

8. Concentration of Ions in Solution After Leaching

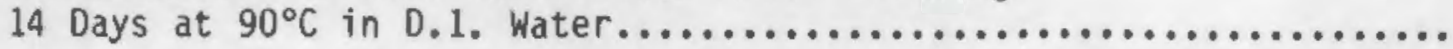


9. Oxide Composition of Individual Clinkers and Fines

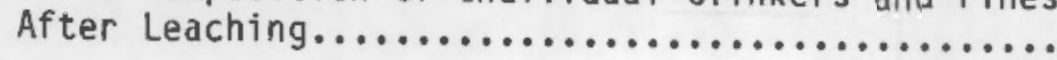




\section{EXECUTIVE SUMMARY}

This report contains information on the operation of a controlled-air incinerator (CAI) which burned wastes that are similar to those generated by a light-water reactor. Ashes that were produced during the operation of the CAI are also described.

Incineration of low-level radioactive waste (LLW) is being viewed with increasing interest for several reasons. First, rising disposal costs for LLW have provided an incentive for reducing the volume of combustible wastes through incineration. Further, incineration entances the safety of handling and disposal of combustible waste by rendering it more chemically inert. Moreover, incinerator ashes that are solidified ensure the stability of the waste burial site. This is an important consideration of the U.S. Nuclear Regulatory Commission (10 CFR 61).

Several sources were consulted to develop a reference, light-water-reactor (LWR), combustible-waste composition. A total of $4540 \mathrm{~kg}(10,000 \mathrm{lb})$ of the various reference waste components was procured. None of the wastes was radioactive. The wastes were packaged in $0.063 \mathrm{~m}^{3}\left(2.2 \mathrm{ft}^{3}\right)$ cardboard boxes to facilitate charging them to a CAI similar to a type developed with the support of the U.S. Department of Energy (DOE). The wastes were incinerated in two runs: the first involved resins and simulated crud, and the second involved general trash (plastics, paper, wood, rubber and cloth). Results are tabulated below:

\begin{tabular}{|c|c|c|c|c|c|c|}
\hline \multirow[b]{2}{*}{ Run } & \multirow[b]{2}{*}{ Charging Rate } & \multicolumn{2}{|c|}{$\begin{array}{c}\text { Average Charging } \\
\text { Temperature }\end{array}$} & \multirow{2}{*}{$\begin{array}{c}\text { Ash } \\
\text { Recovered } \\
\end{array}$} & \multirow{2}{*}{$\begin{array}{r}\text { Ash Bulk } \\
\text { Density } \\
\end{array}$} & \multirow{2}{*}{$\begin{array}{c}\text { Volume } \\
\text { Reduction Ratio }\end{array}$} \\
\hline & & Lower & Upper & & & \\
\hline & $\begin{array}{l}58 \mathrm{~kg} / \mathrm{h} \\
52 \mathrm{~kg} / \mathrm{h}\end{array}$ & $\begin{array}{l}800^{\circ} \mathrm{C} \\
870^{\circ} \mathrm{C}\end{array}$ & $\begin{array}{l}970^{\circ} \mathrm{C} \\
820^{\circ} \mathrm{C}\end{array}$ & $\begin{array}{l}148 \mathrm{~kg} \\
122 \mathrm{~kg}\end{array}$ & $\begin{array}{l}0.9 \mathrm{~g} / \mathrm{cm}^{3} \\
0.3 \mathrm{~g} / \mathrm{cm}^{3}\end{array}$ & $\begin{array}{l}13: 1 \\
22: 1\end{array}$ \\
\hline
\end{tabular}

Incineration rates did not seem to be affected by the type of wastes burned. The burning rate of the general trash wastes was lower than expected, especially since the burning waste was frequently stoked to encourage combustion. Low burning rates may have been caused by 1) somewhat lower than desired burning temperatures, 2) high package masses that may have prevented combustion air and heat from efficiently reaching the center of the package, and 3 ) high waste densities that may have produced the same effect. These factors may also be related to the high content of volatile chemicals in the ash (40 wt\%). It appears that high burning temperatures, low package weights, and low waste densities may all be important in assuring high burning rates, low volatile contents, and high volume-reduction ratios.

Analyses of non-volatile tracer chemicals in the ash indicated that approximately $20 \mathrm{wt} \%$ of the resin ash was lost due to entrainment in the off gas and adherence to the incinerator walls. Losses of the volatile cesium and iodine tracers in the blended ash were $79 \%$ and $100 \%$, respectively. Assessment of off-gas characteristics and efficiency of removing volatiles and particles from the off-gas stream was not within the scope of this study. The ashes were not hygroscopic. Therefore little risk of ash agglomeration or free-standing 
water exists. However, the $\mathrm{pH}$ of the combined ash ranged between 4.6 and 5.0, a level sufficient to cause corrosion of mild steel if water were inadvertently added during storage. The exposure of combustible materials to hygroscopic salts during normal plant operations could result in producing a wet, acidic ash that could also be quite corrosive to mild steel.

A significant fraction of ash produced in Run 2 consisted of clinkers. Over 5 wt\% was in clinkers greater than $8 \mathrm{~cm}$ ( 3 in.) diameter. Clinkers present a concern since they could jam ash conveyors and ash solidifying systems. Except for some wood-charcoal cinders, the ash clinkers were wellburned and did not disintegrate when reheated. Thus, more efficient combustion may not prevent the formation of some clinkers. The clinkers were fairly easy to crush, however, which suggests that standard comminuting equipment would be effective in pulverizing the clinkers to enable processing the product in the ash solidification system. Some method of separating tramp metal must be employed, however. Clinkers may also be suitable for direct disposal in $210 \mathrm{~L}$ ( 55 gal) drums with a capacity of $114 \mathrm{~kg}(250 \mathrm{lb})$ per drum. Soot which adhered to the surfaces of clinkers was easily washed away with water. If necessary, washing would significantly reduce the potential for dust dispersion from clinkers. 


\section{INTRODUCTION}

The current inventory of low-level radioactive waste (LLW) from defense and commercial industries in the U.S. is $\sim 2 \times 10^{6} \mathrm{~m}^{3}$ and is increasing at a rate of $\sim 10^{5} \mathrm{~m}^{3} / \mathrm{yr}$ at the currert. level of operations (Borduin and Taboas 1981). All the commercial waste is disposed of at commercial burial sites. Since 1975 the number of such sites has been reduced from six to three (DiSibio 1980). Furthermore, the states which contain the three remaining sites have taken actions that have limited the sites' capacities to dispose of low-level wastes (DiSibio 1980). At the same time, disposal costs have risen substantially. These factors provide an incentive to reduce the volume of LLW for disposal.

Most LLW can be classified as combustibles, liquids and sludges, or noncombustible solids. The combustible fraction, comprising about $40 \%$ of the volume of newly generated waste (Borduin and Toboas 1981), has the greatest potential for volune reduction. Most combustible wastes are currently compacted, which reduces their volumes by about $75 \%$. Volume-reduction ratios of $40: 1$ have been reported when incinerating uncompacted wastes (Borduin and Taboas 1981). Proper incineration also results in a more chemically inert waste which enhances the safety of waste handling, packaging, and storage. Further, at least one study (Osmeyer 1980) indicates that incineration is economically attractive.

In 1973 Los Alamos National Laboratory (LANL) was directed by DOE to evaluate current incineration technology for combustion of transuranic (TRU) wastes. A controlled-air incinerator (CAI) was selected for development and demonstration. Advantages of the CAI include 1) flexibility to accept a wide range of feed compositions, 2) ease of combustion rate control, 3) low particulate emissions, 4) high combustion efficiency, and 5) the ability to tolerate relatively high levels of noncombustibles.

In 1981 the U.S. Nuclear Regulatory Commission (NRC) commissioned Pacific Northwest Laboratory (PNL) to characterize volume-reduced LLW forms to provide a basis for policy and licensing decisions. Initial work focused on the combustion of simulated LLW materials using a CAI. Ashes resulting from the incineration were characterized. This report discusses the performance of the CAI and the properties of the ash produced. Subsequent reports will deal with the properties of solidified ashes and their suitabilities for disposal. 



\section{SELECTION OF REFERENCE COMBUSTIBLE WASTE}

A number of sources were consulted to define a combustible waste typical of that generated by a commercial light water reactor (LWR). Combustible waste components and their concentrations from four sources are itemized in Table 1. The first source (USDOE 1979) provided data obtained from a survey of several LWRs. The second source (TROJAN Nuclear Power Plant, Rainier, Oregon) provided data that was reasonably consistent with the first. It represented only the TROJAN Nuclear Power Plant, however. The third source (Combustion Engineering, Inc., Windsor, Connecticut) did not include resins and indicated that paper was the major type of combustible waste. The fourth source (0smeyer 1980) divided the waste into only two categories: trash and resin waste.

\section{TABLE 1. Components of Combustible LLW, wt\%}

\begin{tabular}{|c|c|c|c|c|}
\hline \multirow[b]{2}{*}{ Component } & \multicolumn{4}{|c|}{ Sources } \\
\hline & USDOE & TROJAN & $\begin{array}{l}\text { Combustion } \\
\text { Engineering }\end{array}$ & Osmeyer \\
\hline TRASH & $\underline{56}$ & 60 & 100 & 82 \\
\hline $\begin{array}{l}\text { (Plastics) } \\
{[\text { PVC }]} \\
{[\text { Polyethylene }]}\end{array}$ & (36) & ${ }_{[}^{(42)}$ & $(12.2)$ & \\
\hline $\begin{array}{l}\text { (Paper) } \\
{[\text { Sulfite] }} \\
{[\text { Kraft }]}\end{array}$ & (12) & (9) & $(67.7)$ & \\
\hline $\begin{array}{l}\text { (Wood) } \\
\text { (Rubber) } \\
\text { (Cloth) }\end{array}$ & $\begin{array}{l}(4) \\
(3) \\
(1)\end{array}$ & $\begin{array}{l}(4.8) \\
(1.2) \\
(3)\end{array}$ & $\begin{array}{r}(1.4) \\
(10.8) \\
(7.9)\end{array}$ & \\
\hline RESINS (low activity) & 44 & 40 & & 18 \\
\hline $\begin{array}{l}\text { (Cation Resin) } \\
\text { (Anion Resin) } \\
\text { (Crud) }\end{array}$ & & $\begin{array}{l}(29) \\
(9) \\
(2)\end{array}$ & & \\
\hline TOTALS (Trash + Resins & 100 & 100 & 100 & 100 \\
\hline
\end{tabular}

Although the TROJAN source provided the most definitive breakdown, the DOE source was selected because it was more representative. The definition of DOE source wastes was broadened, however, by dividing the plastic category into polyvinyl chloride (PVC) and polyethylene subcategories, and the paper category into sulfite and Kraft paper subcategories, in proportion to the TROJAN levels. Also, the resin category was divided into cation exchange resins, anion exchange resins and "crud," again in proportion to the TROJAN levels. "Crud" is a mixture of metallic oxides resulting from the corrosion of process pipes and vessels. The reference combustible waste is shown in Table 2. Note that wood is defined as fir, rubber as latex, and cloth as cotton. (TROJAN was again the source of this information). 
Plastics were obtained as shredded scrap ( $<1 \mathrm{~cm}$ or $0.4 \mathrm{in.)}$ from Talco Plastics, El Monte, California. Scrap computer paper served as the source of sulfite paper. Paper towels were used for Kraft paper. Douglas fir chips $(3 \mathrm{~cm} \times 3 \mathrm{~cm} \times 0.3 \mathrm{~cm}$, or 1 in. $\times 1$ in. $\times 1 / 8 \mathrm{in.}$ ) were donated by the Boise Cascade Corporation, Wallula, Washington. Cotton rags represented the cloth category. Slightly off-specification, beaded resins were purchased from Diamond Shamrock Corporation, Cleveland, Ohio. The cation exchange resin was a hydrogen form, sulfonated polystyrene cross-linked with divinylbenzene. The

\section{TABLE 2. Reference LWR Combustible LLW, wt\%}

Component
PVC Plastic
Polyethylene Plastic
Sulfite Paper
Kraft Paper
Wood (fir)
Rubber (latex)
Cloth (cotton)
Cation Exchange Resin
Anion Exchange Resin
Crud (a)
TOTAL
(a) Crud: $80 \% \mathrm{Fe}_{2} \mathrm{O}_{3}, 20 \% \mathrm{Cu} 0$.

anion exchange resin was a hydroxide form, strong base (quaternary ammonium functional group) polystyrene cross-linked with divinylbenzene. A blend of powdered, technical grade $\mathrm{Fe}_{2} \mathrm{O}_{3}$ and CuO served as crud. A total of $4540 \mathrm{~kg}$ $(10,0001 \mathrm{~b})$ of these simulated wastes was procured. 


\section{WASTE PACKAGING}

Discussions with operators of controlled-air incinerators at Los Alamos National Laboratory (LANL) and Environmental Control Products, Inc., Charlotte, North Carolina revealed that wastes typical of those in this study are usually packaged before charging in the incinerator. Cardboard boxes serve as suitable containers because they are themselves combustible. A $40 \mathrm{~cm} \times 40 \mathrm{~cm} \times 38 \mathrm{~cm}$ (16 in. x 16 in. x 15 in.) cardboard box was chosen as the standard packaging container as it was deemed large and strong enough to minimize handling but small enough that the contents should burn relatively well.

Wastes were divided into two categories: resins and trash. In actual practice these wastes may be generated and incinerated separately rather than as blends. The trash wastes (plastics, paper, rubber, cloth, and wood) were loaded into plastic bags which lined each box, blending some of the various trashes together as might be expected in the actual application. Trash weights in each box ranged between 11 and $27 \mathrm{~kg}$ ( 25 and $60 \mathrm{lb}$ ). Generally each box of trash was filled nearly to capacity, but wastes were not compressed. Resins containing about $50 \%$ water were also loaded into plastic-lined boxes. However, the moisture content and activity level of resins may be too high to practically charge resins in boxes. A continuous charging method may be more suitable. Crud, which represented about 5 wt\% of the resin weight in each box, was blended by hand with the resin. About 34 to $36 \mathrm{~kg}$ (75 to $80 \mathrm{lb}$ ) of the resin and crud blend were contained in each package. These packages were not filled to capacity because of the possibility that due to the high density $(0.8$ $\mathrm{g} / \mathrm{cc}$ or $50 \mathrm{lb} / \mathrm{ft}^{3}$ ), the boxes might rupture.

Before each package was sealed, approximately $300 \mathrm{cc}$ of a simulated radioactive spiking solution were added to each box. These spiking chenicals serve as tracers for performing leaching studies on consolidated ash waste forms.

Two different spiking solutions were prepared as shown in Table 3 . The selection of spiking chemicals was based on the radioactive spiking elements used in studies at Brookhaven National Laboratory (Colombo and Neilson 1979). The use of similar spiking chemicals will facilitate the comparison of data. Batch $A$ was added to trash packages, while Batch B was added to resin packages. The higher chemical concentration of Batch B is attributed to the higher fission product level of the resins (USDOE 1979). The overall quantity of spiking chemicals added was based on the amount necessary to observe leaching by the inductively-coupled plasma emission spectrometry and atomic absorption methods. We estimated that $160 \mathrm{~kg}$ (350 1b) of ash would be recovered and then we added chemicals so that $1 / 2$ wt $\%$ each of cesium and strontium and 1 wt\% each of cobalt and iodine would exist in the ash. This was assuming, of course, that none of the chemicals would vaporize, although it was doubtful that much iodine would be retained. 
TABLE 3. Combustible Waste Spiking Solutions

\begin{tabular}{lrrr} 
Compounds & & Batch A & Batch B \\
\cline { 1 - 1 } $\mathrm{CsNO}$ & & $126 \mathrm{~g}$ & $710 \mathrm{~g}$ \\
$\mathrm{Sr}\left(\mathrm{NO}_{3}\right)_{2}$ & $204 \mathrm{~g}$ & $1150 \mathrm{~g}$ \\
$\mathrm{Co}\left(\mathrm{NO}_{3}\right)_{2}$ & $852 \mathrm{~g}$ & $4824 \mathrm{~g}$ \\
$\mathrm{CaI} \mathrm{I}_{2}$ & $200 \mathrm{~g}$ & $1123 \mathrm{~g}$ \\
$\mathrm{H}_{2} \mathrm{O}$ & $41 \mathrm{~L}$ & $21 \mathrm{~L}$
\end{tabular}




\section{INCINERATION}

The combustible waste was incinerated in a Model 500-T CAI manufactured by Environmental Control Products, Inc. (ECP), a company instrumental in the early development of the CAI at LANL. The incinerator is located at Battelle Columbus Laboratories, Columbus, Ohio. The unit features a $940 \mathrm{~kW}(3.2 \mathrm{million}$ BTU/h) thermal capacity, which corresponds to an incineration feed rate of approximately $182 \mathrm{~kg} / \mathrm{h}(400 \mathrm{lb} / \mathrm{h})$ of normal, dry combustible waste.

A schematic of the incinerator is shown in Figure 1. The unit consists of two drum-shaped burning chambers, one positioned on top of the other. Wastes were charged batchwise in the lower incinerator chamber. Air was added under the fire at nearly the stoichiometric oxygen requirement for complete combustion, thus controlling the burning rate of the waste. Unburned volatile compounds and combustible particles were then burned completely in the upper chamber, where additional air for combustion was added. Temperatures of approximately 850 and $900^{\circ} \mathrm{C}$ were maintained in the lower and upper chambers, respectively, by the introduction of natural gas. Flow rates of natural gas and combustion air were manually regulated. Exhaust gases from the upper chamber were vented directly to a stack.

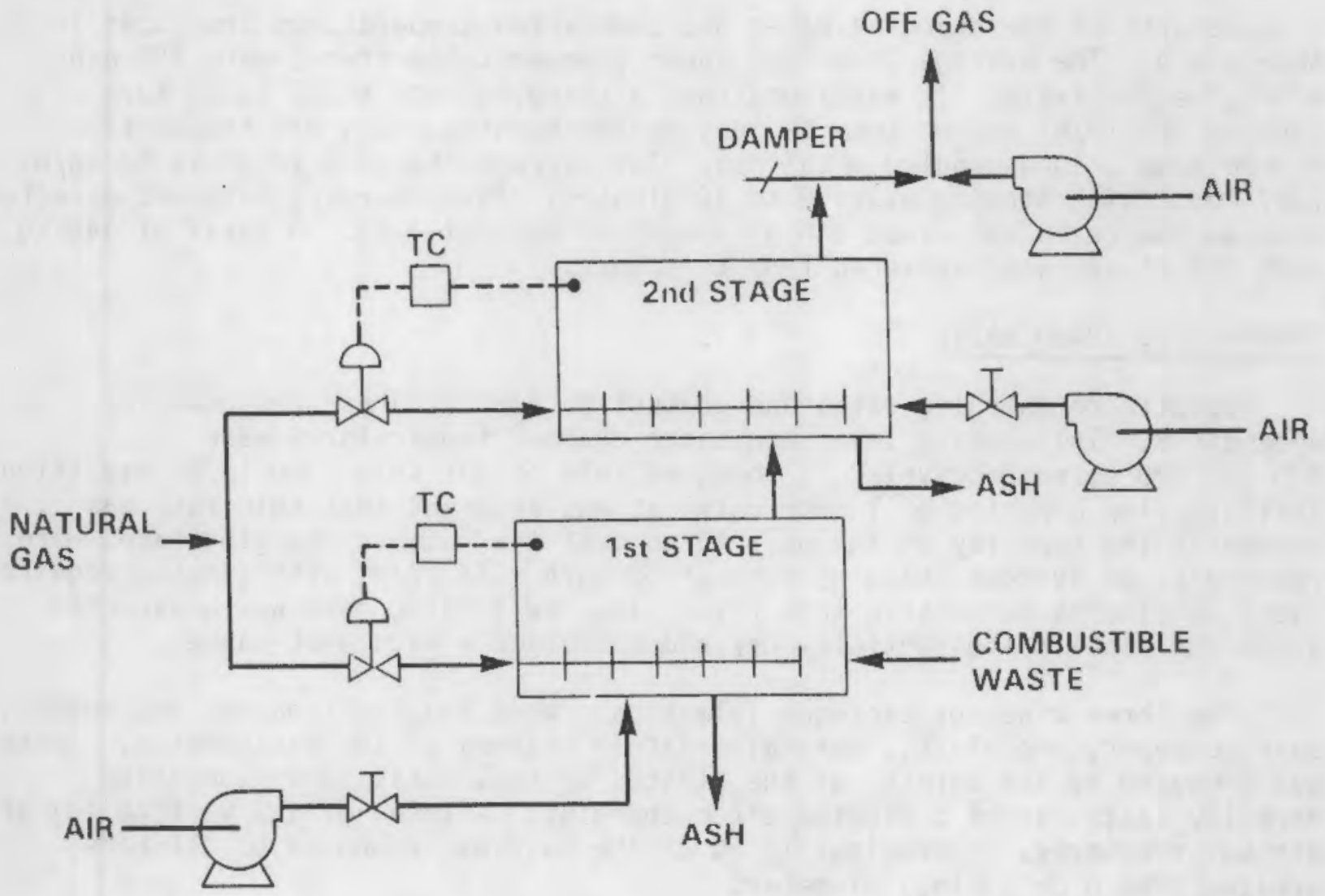

FIGURE 1. Controlled-Air Incinerator 
The resin wastes and the trash wastes were incinerated separately in two runs. Prior to each run the incinerator was thoroughly swept and vacuumed to minimize the potential for contamination of the ashes. Before charging packaged waste, the incinerator was brought to operating temperatures by firing only with natural gas. Once the desired temperatures were achieved, waste packages were charged individually to the incinerator via an electricallyoperated access door. A safety interlock prevented the operation of the natural gas burners while the access door was open. With the door open, a damper in the off-gas line automatically closed, which reduced the draft through the furnace and minimized the temperature drop. Approximately 30 seconds after the door was closed, natural gas injection was resumed, which quickly raised temperatures to normal operating levels.

During the burns different waste charging rates were explored until a suitable rate was found. At the end of each burn, the incinerator was left operating for approximately 8 hours. The incinerator was then shut down and the ash was permitted to cool for approximately 24 hours, at which point it was removed from the incinerator and stored in steel $210 \mathrm{~L}$ ( $55 \mathrm{gal}$ ) drums.

BURN NO. 1, RESIN WASTE

Details of the charging rates and combustion temperatures are shown in Appendix A. The average lower and upper chamber temperatures were 800 and $970^{\circ} \mathrm{C}$, respectively. It was found that a charging rate of 45 to $73 \mathrm{~kg} / \mathrm{h}$ (100 to $160 \mathrm{lb} / \mathrm{h}$ ) was optimum as long as the burning resin was frequently stoked with a long-handled metal hoe. The average charging rate was $58 \mathrm{~kg} / \mathrm{h}$ $(127 \mathrm{lb} / \mathrm{h})$ with stoking every 8 to 10 minutes. This charging rate was expected because the resin contained a high amount of water $(\sim 50 \%)$. A total of $148 \mathrm{~kg}$ (325 lb) of ash was recovered from this burn.

BURN NO. 2, TRASH WASTE

Details of charging rates and combustion temperatures are shown in Appendix $B$. The average lower and upper chamber temperatures were 870 and $820^{\circ} \mathrm{C}$, respectively. A charging rate of $136 \mathrm{~kg} / \mathrm{h}(300 \mathrm{lb} / \mathrm{h})$ was tried initially for a period of 1 hour until it was apparent that this rate was exceeding the capacity of the unit to combust the waste. Charging rates were reduced to an average charging rate of $52 \mathrm{~kg} / \mathrm{h}(115 \mathrm{lb} / \mathrm{h})$ with stoking required every 10 minutes to achieve this rate. The low burning rate was unexpected since the waste was essentially dry and contained a high heat value.

The three kinds of packages (plastics; wood and Kraft paper; and rubber, sulfite paper, and cloth), were alternately charged to the incinerator. Smoke was produced by the burning of the plastic wastes. This smoky condition normally lasted about 5 minutes after charging. A total of $122 \mathrm{~kg}$ (268 lb) of ash was recovered. Approximately $5 \%$ of the mass was composed of clinkers greater than $8 \mathrm{~cm}(3 \mathrm{in.})$ diameter.

DISCUSSION OF INCINERATION RESULTS

Burning rates did not seem to be significantly affected by the type of wastes being burned. $\mathrm{BCL}$ operators estimated that burning rates would have 
been reduced by more than half had stoking not been used. Apparently the burned crust that covered each burning package inhibited the flow of air into the package and thereby reduced the burning rate. This suggests that a smaller, less dense charge size may be critical in maximizing burning rates. Our use of shredded wastes having high bulk densities $(0.2$ to $0.9 \mathrm{~g} / \mathrm{cc}$, or 11 to $55 \mathrm{lb} / \mathrm{ft}^{3}$ ) undoubtedly restricted oxygen availability at the center of the burning package. At LANL, TRU contaminated wastes were burned in packages of similar volume that contained $4 \mathrm{~kg}$ ( 9 1b) (Borduin and Taboas 1981), as compared to the 12 to $36 \mathrm{~kg}$ (26 to $80 \mathrm{lb}$ ) charges in this study. Moreover, LANL reports combustion temperatures of 800 to $1000^{\circ} \mathrm{C}$ in the lower chamber and $1100^{\circ} \mathrm{C}$ in the upper chamber. These higher temperatures may also account, in part, for the relative ease of combustion. Also, less smoke might have been produced when burning the plastics had the upper chamber been operated at $1100^{\circ} \mathrm{C}$.

Even though the bulk density of the waste was relatively high before incineration, volume-reduction ratios of 13:1 and 22:1 were achieved with the resin waste and trash waste, respectively.

Ralph Koenig of LANL subsequently reported that the LANL incinerator experience generally agreed with the results of this study. Highlights of the LANL experiences are provided below:

- Low burning rates and clinker formation occurred when burning compacted material such as stacks of computer print-out paper and stacks of polyethylene film. Burning rates increased dramatically when this type of material was shredded and repackaged.

- Higher temperatures in the upper chamber helped to reduce smoke, but other changes were required to completely eliminate it, including redesigning the upper chamber air injector, better controlling oxygen levels in the exhaust, and injecting steam. 



\section{ASH CHARACTERIZATION}

Approximately 2 months after the ash was produced, samples were collected at the top, middle, and bottom of each drum of ash. For several weeks prior to removing the samples, the drums were loosely lidded to permit air to enter the drums. We were concerned that these ashes might have exhibited a hygroscopic nature that could have resulted in the presence of free-standing liquids and container corrosion. However, a moisture analysis of the samples revealed no relationship between water content and position in the drum, which suggests that these ashes are not highly hygroscopic. The average moisture contents of the resin and trash ashes were 0.39 and $0.37 \mathrm{wt} \%$, respectively. Moisture content was determined by drying the samples at $110^{\circ} \mathrm{C}$ for 16 hours and measuring weight loss. Densities of the bulk resin and trash ashes were 0.9 and $0.3 \mathrm{~g} / \mathrm{cm}^{3}$ respectively.

To prepare the ashes for further analyses and solidification, large (>2.5 cm, or 1 in.) clinkers were separated from the resin and trash ashes. Most of the remaining ash was blended in the same weight proportion as the ash was produced (325 parts of resin ash to 268 parts of trash ash). The blended ash was then screened through a $0.6 \mathrm{~cm}$ (1/4 in.) mesh screen. The coarse fraction, when combined with the large clinkers, comprised 12 wt\% of the ash produced. The separation step was necessary to ensure that the ashes, when combined with solidifying agents and cast in small molds, would not be dominated in some samples by the presence of large particles which may not have chemical and physical properties typical of the fine ashes. The bulk density of the blended ash was $0.9 \mathrm{~g} / \mathrm{cm}^{3}$.

Both the fine ashes (before and after blending) and the clinkers were characterized as follows.

FINE ASHES

X-Ray Diffraction

Although both ashes were primarily amorphous, three distinct crystalline phases were found in the resin ash. The main phase was essentially $\mathrm{Fe}_{2} \mathrm{O}_{3}$ (hematite). The second phase was a solid/solution between $\mathrm{Fe}_{3} \mathrm{O}_{4}$ and $\mathrm{CuFe}_{2} \mathrm{O}_{4}$ with a spinel structure, while the third phase was probably a Fe-Cu sulfide. The trash ash analysis revealed a distinct amorphous "hump" that can be attributed to the presence of carbon. Two or three crystalline phases appear to be present, but they were not identified.

\section{Brunaver-Emmett-Teller (BET) Surface Area}

BET surface area measurements, based on $\mathrm{N}_{2}$ adsorption at liquid nitrogen temperatures, resulted in values of $3.68 \mathrm{~m}^{2} / \mathrm{g}$ and $33.27 \mathrm{~m}^{2} / \mathrm{g}$ for the trash and resin ash, respectively. The large surface area in the resin ash was due to extensive microporosity and rough surfaces present in the particles. The higher surface area of the resin ash was not surprising since it is a characteristic of unburned resins. Evidence of this is seen in the scanning electron microscope (SEM) micrographs discussed later. 
Thermogravimetric Analysis-Differential Thermal Analysis (TGA-DTA)

Simultaneous TGA-DTA was conducted on samples of trash, resin, and blended ashes. The samples were heated in air at $300^{\circ} \mathrm{C} / \mathrm{h}$ to $800^{\circ} \mathrm{C}$, and held there for 4 hours. The total weight losses of the three samples at the end of the analysis were 40.6, 50.9, and $41.8 \mathrm{wt} \%$ for the trash, resin, and blended ashes, respectively. Figure 2 illustrates the weight loss of the trash and resin ashes as a function of temperature and time. After a slight (and perhaps anomalous) weight gain between 200 and $400^{\circ} \mathrm{C}$, both ashes lost weight rapidly with increasing temperature. The trash ash continued to lose weight at $800^{\circ} \mathrm{C}$ for about 40 minutes, after which the weight loss stabilized, reaching a total loss of $40.6 \mathrm{wt} \%$ after 4 hours. The weight loss of the resin ash progressed at a slower rate than the trash ash and continued until about $21 / 2$ hours at $800^{\circ} \mathrm{C}$, reaching a total loss of $50.9 \mathrm{wt} \%$ after 4 hours. Exothermic peaks were observed at 750 and $800^{\circ} \mathrm{C}$ for resin ash and trash ash, respectively, perhaps signifying ignition of residual carbon.

Quadrupole Mass Spectrometry (QMS)

Gases evolved from samples of ash heated in air were analyzed by QMS. Samples of trash, resin, and blended ashes were heated at $300^{\circ} \mathrm{C} / \mathrm{h}$ to $800^{\circ} \mathrm{C}$ and held there for 4 hours, as in the TGA-DTA analyses. Gas analyses showed the only gases detected were $\mathrm{CO}_{2}$ and $\mathrm{SO}_{2}$. There was no detectable $\mathrm{NO}_{x}, \mathrm{H}_{2} \mathrm{O}$, or $\mathrm{CH}_{4}$. The bulk of the gas was $\mathrm{CO}_{2}$, which comprised $>99 \%$ of the total quantity of gas released. Evolution of $\mathrm{SO}_{2}$ was the highest from the resin and blended ash samples. This was expected because of the high sulfur content of resins. Since heating of the samples was terminated at $800^{\circ} \mathrm{C}$, 1ittle decomposition of carbonates should have occurred. Thus, it is concluded that essentially all of the weight loss can be attributed to oxidation of carbon. The absence of $\mathrm{H}_{2} \mathrm{O}$ and $\mathrm{CH}_{4}$ in the gas suggests that the carbon was essentially elemental in form. QMS data are shown in Appendix $C$.

Scanning Electron Microscopy/Energy Dispersive Analysis by X-Ray (SEM/EDAX)

The SEM revealed that the trash ash consisted of three basic particle types, as seen in the micrographs in Figure 3 . The most abundant particle type (Photo A) is believed to contain substantial carbon because of its extremely low EDAX peaks and its particular morphology. Photo B shows another particle which has a grainy surface texture. This particle is composed primarily of $A l$, $\mathrm{Si}, \mathrm{Ca}, \mathrm{K}$, and $\mathrm{Ti}$, with traces of $\mathrm{Fe}$ and $\mathrm{S}$, as seen in the EDAX trace in Figure 4. The third type of particle, seen in Photo $C$, is characterized by a rough surface containing numerous craters. The EDAX spectra of this particle (Figure 4) is similar to that of the previously discussed particle in the major elements; however, $\mathrm{S}, \mathrm{Cl}$, and $\mathrm{Na}$ are present in substantial amounts.

Nearly all the particles in the resin ash sample were spherical in shape, but they had widely different morphologies. The two particles seen in Figure 5 have spherical shapes with large pore structures, which may account for the large BET surface area measured for this ash. Figure 6 illustrates two more resin ash particles, one nearly spherical and the other irregularly shaped. The spherical particle has a relatively smooth-textured surface, while the irregularly-shaped particle has a very rough surface. Some of the spheres 
examined had numerous small particles adhering to their surfaces, as seen in Figure 7. EDAX analysis of the resin ash particles showed nearly the same overall composition for all particles. An EDAX trace of a typical particle is shown in Figure 8.

\section{Chemical Analysis by Inductively Coupled Plasma (ICP) Emission Spectrometry}

As-received and calcined samples of dry trash and resin ashes and a ballmilled sample of blended ash were analyzed by ICP. Calcining was conducted at $800^{\circ} \mathrm{C}$ for 16 hours in static air. The blended ash sample was ball-milled in alcohol for 12 hours using stabilized zirconia grinding media. The oxide composition of the three materials is shown in Table 4.

The major constituents of trash ash, assumed to be oxides, are $\mathrm{SiO}_{2}$, $\mathrm{Al}_{2} \mathrm{O}_{3}, \mathrm{CaO}$, and $\mathrm{TiO}_{2}$, with lesser amounts of $\mathrm{Fe}_{2} \mathrm{O}_{3}, \mathrm{~K}_{2} \mathrm{O}, \mathrm{MgO}, \mathrm{Na}_{2} \mathrm{O}$, and $\mathrm{P}_{2} \mathrm{O}_{5}$. The total oxide weight in the as-recieved trash ash was 56.6 wt\%, suggesting substantial residual carbon or other non-decomposed compounds. From the TGA data (Figure 2) a 60\% oxide weight can be inferred which closely agrees with the ICP data. Some particles examined by SEM/EDAX contained substantial amounts of $\mathrm{Cl}$, probably originating from PVC plastic. Residual carbon is also suggested by weak EDAX peaks and by the substantial increase in relative weight percent oxides (56.6 to 92.5 wt\%) after calcination.

The resin ash consisted largely of $\mathrm{Fe}, \mathrm{Cu}$, and $\mathrm{S}$ as seen in the EDAX trace (Figure 8). $\mathrm{Fe}_{2} \mathrm{O}_{3}$ and $\mathrm{CuO}$ were added in substantial amounts to the resin before burning to simulate crud. The Fe content in the ash (listed in the table as $\mathrm{Fe}_{2} \mathrm{O}_{3}$ ) is believed to exist in part as $\mathrm{Fe}_{3} \mathrm{O}_{4}$ because of the magnetic properties of the ash particles. Calcination did not increase the relative oxide content of the resin ash ( 53.2 to $69.8 \mathrm{wt} \%$ ) as much as it did the trash ash. The difference is most likely due to the presence of more refractory sulfur compounds. ICP and TGA oxide values (53 and 50\%, respectively) agree closely.

Table 5 gives the percents of spiking chemicals added to combustible wastes that were recovered in the ashes.

From these data we conclude that virtually all of the iodine vaporized and that the retention of cesium was only about one-quarter that of strontium and cobalt. The impossibly high retention of strontium and cobalt in the dry trash ash may be attributed to 1) sampling bias, 2) their innate presence in the combustible waste, 3) cross-contamination from materials left in the incinerator, and/or 4) analytical inaccuracy. 


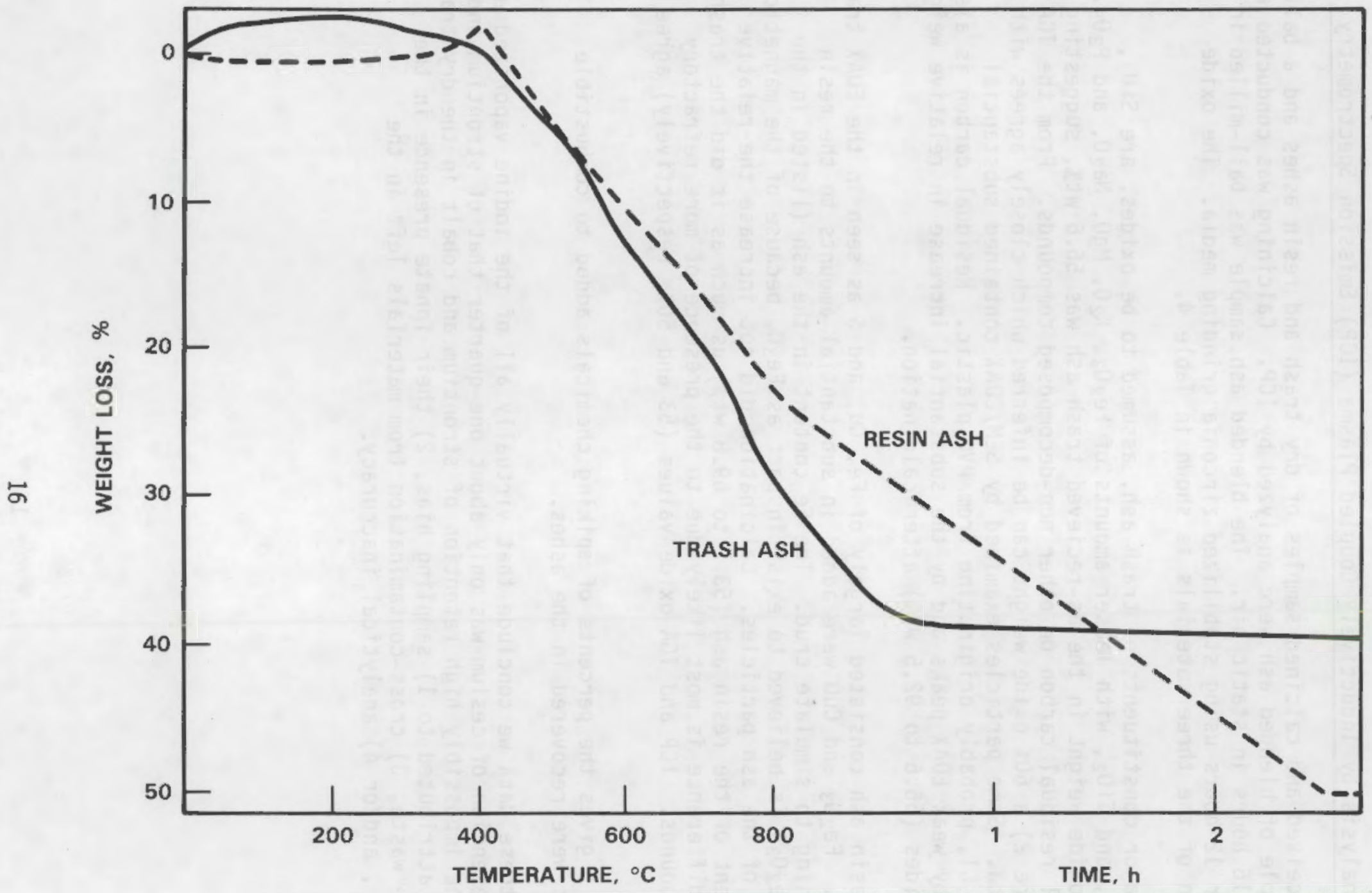

FIGURE 2. TGA Weight Loss of Resin Ash and Trash Ash Heated at $300^{\circ} \mathrm{C} / \mathrm{h}$ in Air 

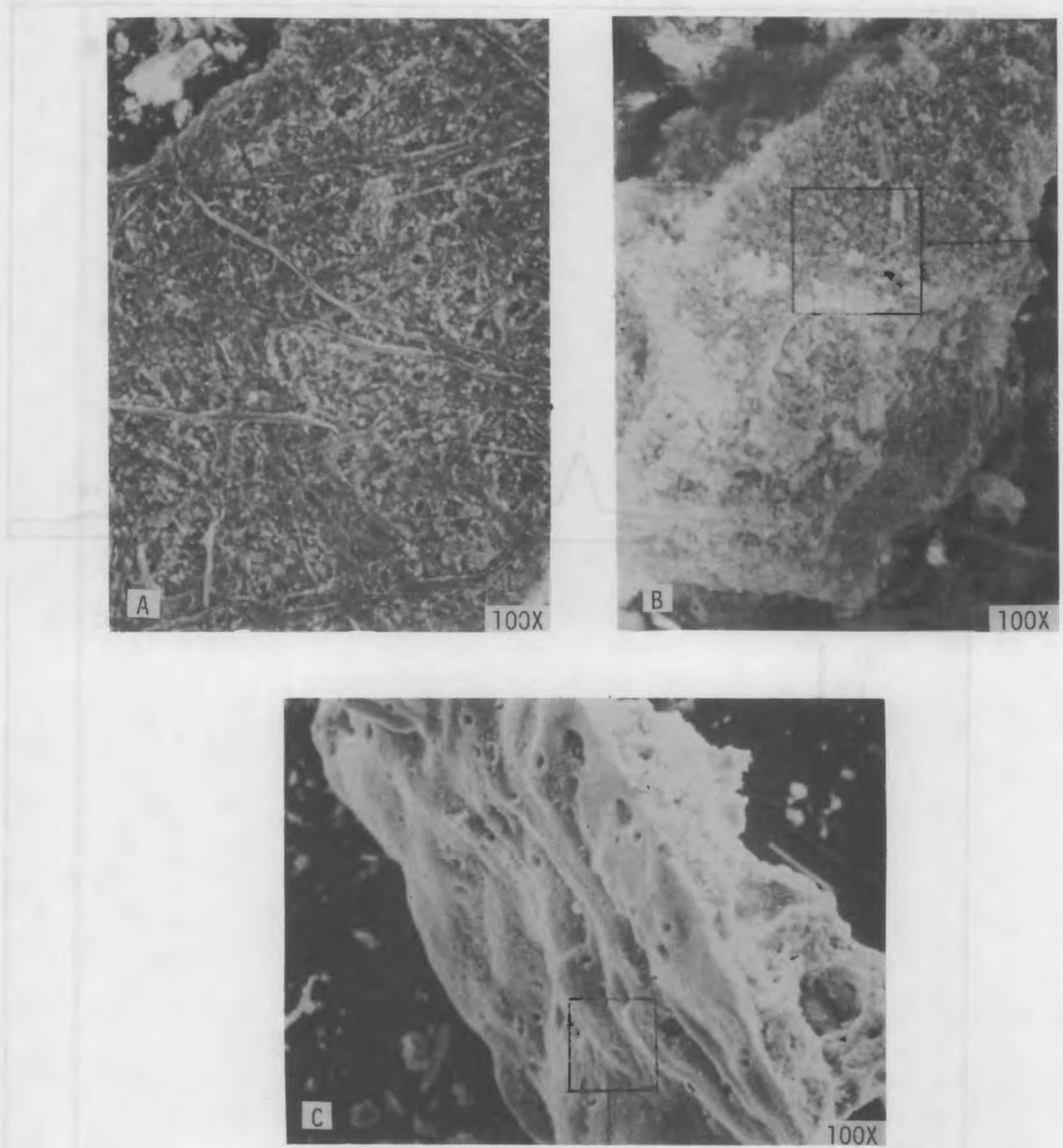

FIGURE 3. SEM Micrographs of Typical Trash Ash Particles 

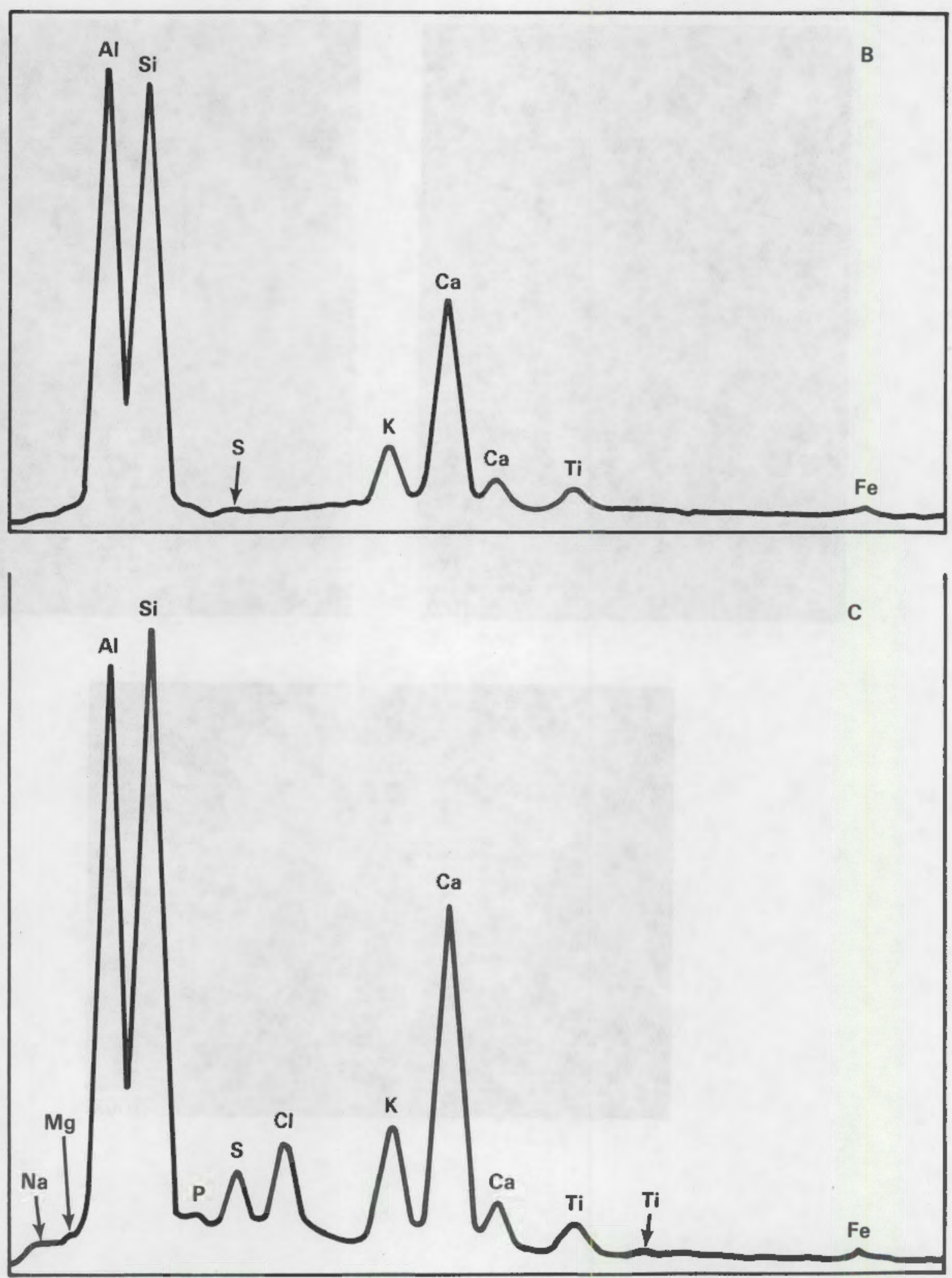

FIGURE 4. EDAX Spectra of Trash Ash Particles Seen in Photos B and C of Figure 3 


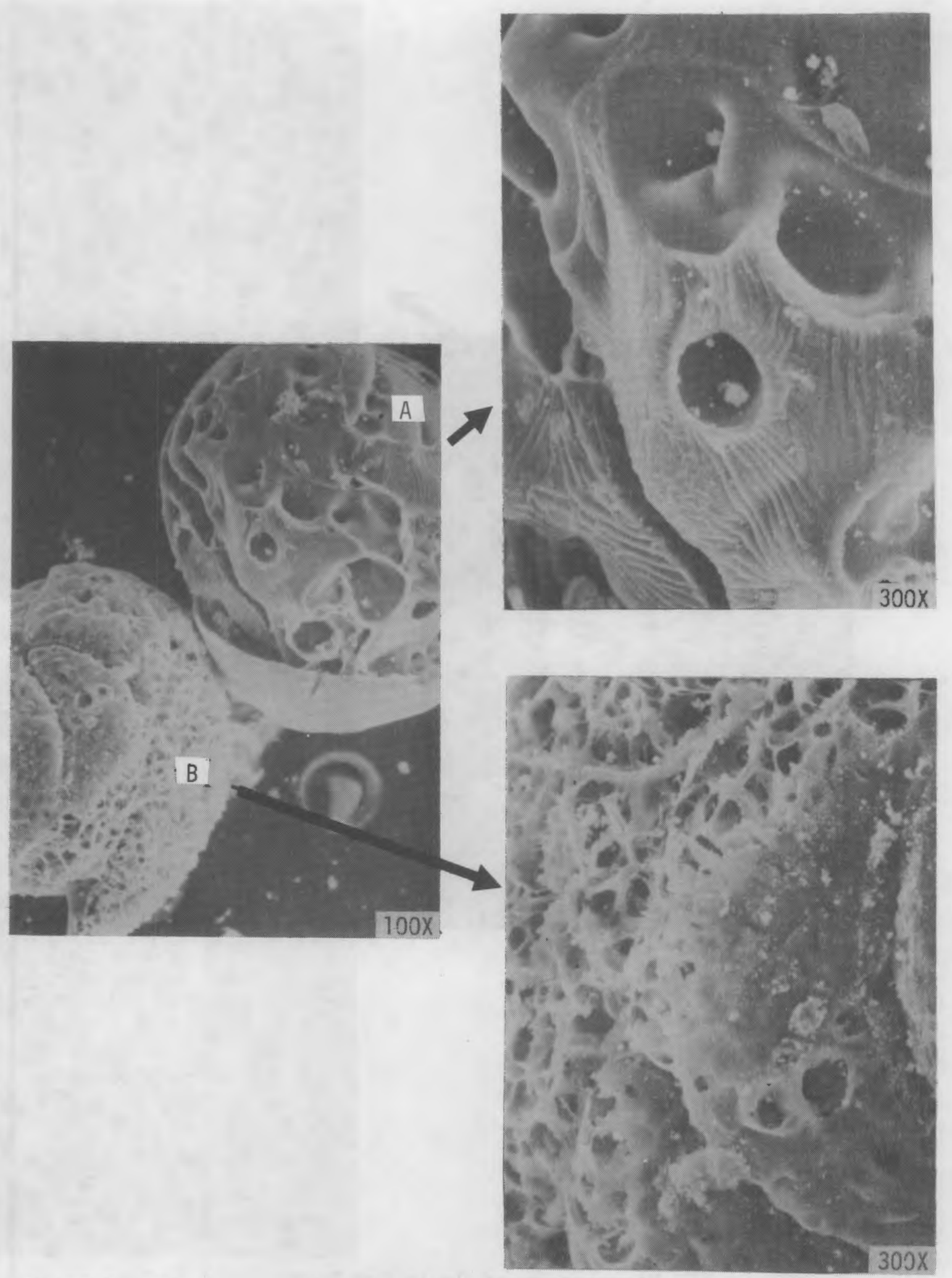

FIGURE 5. SEM Microaraphs of Resin Ash Particles A and B 


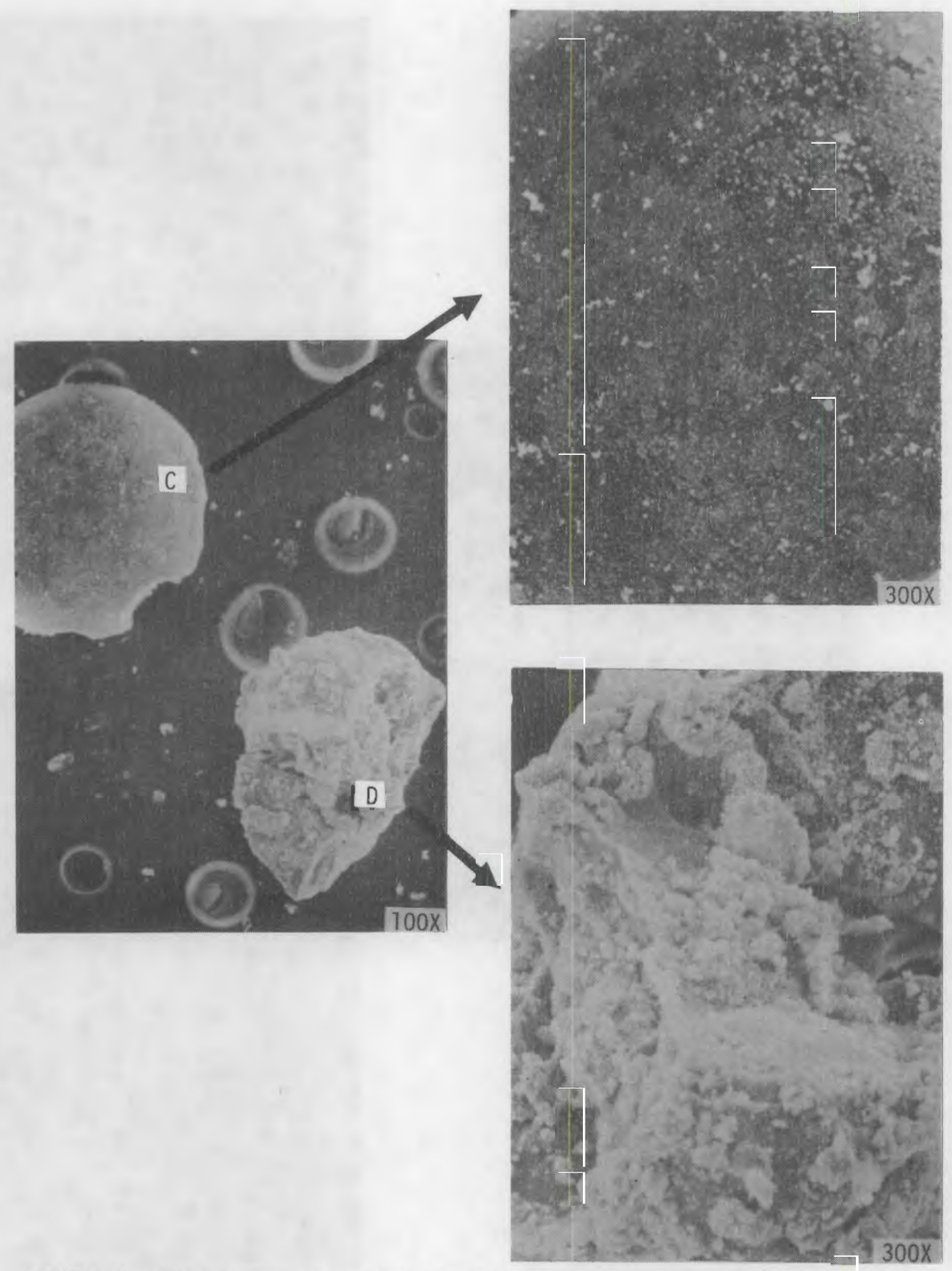

FIGURE 6 SEM Micrographs of Resin Ash Particles C and D 


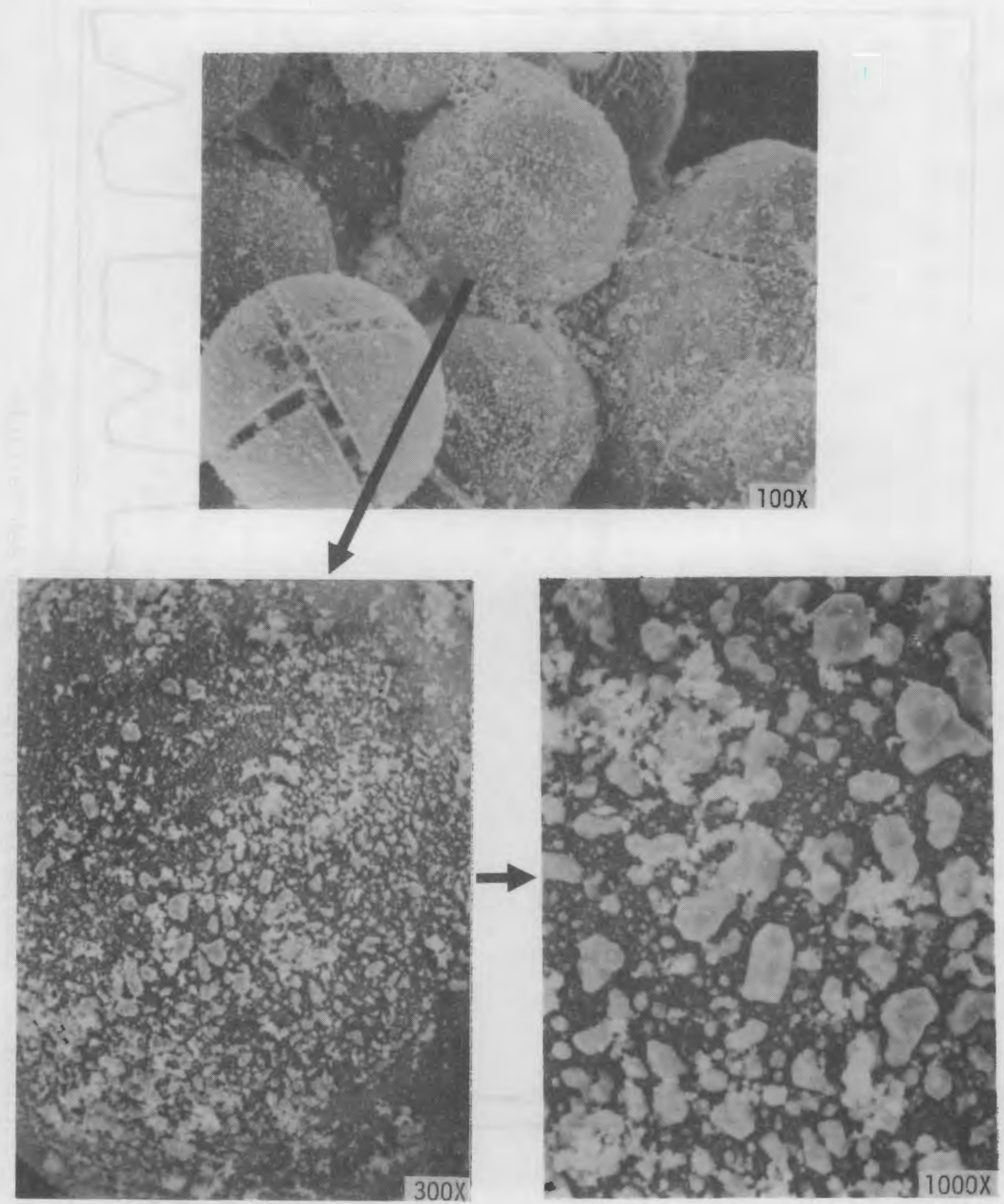

FIGURE 7 SEM Micrographs of a Resin Ash Particle Showing Adhered Crystals 


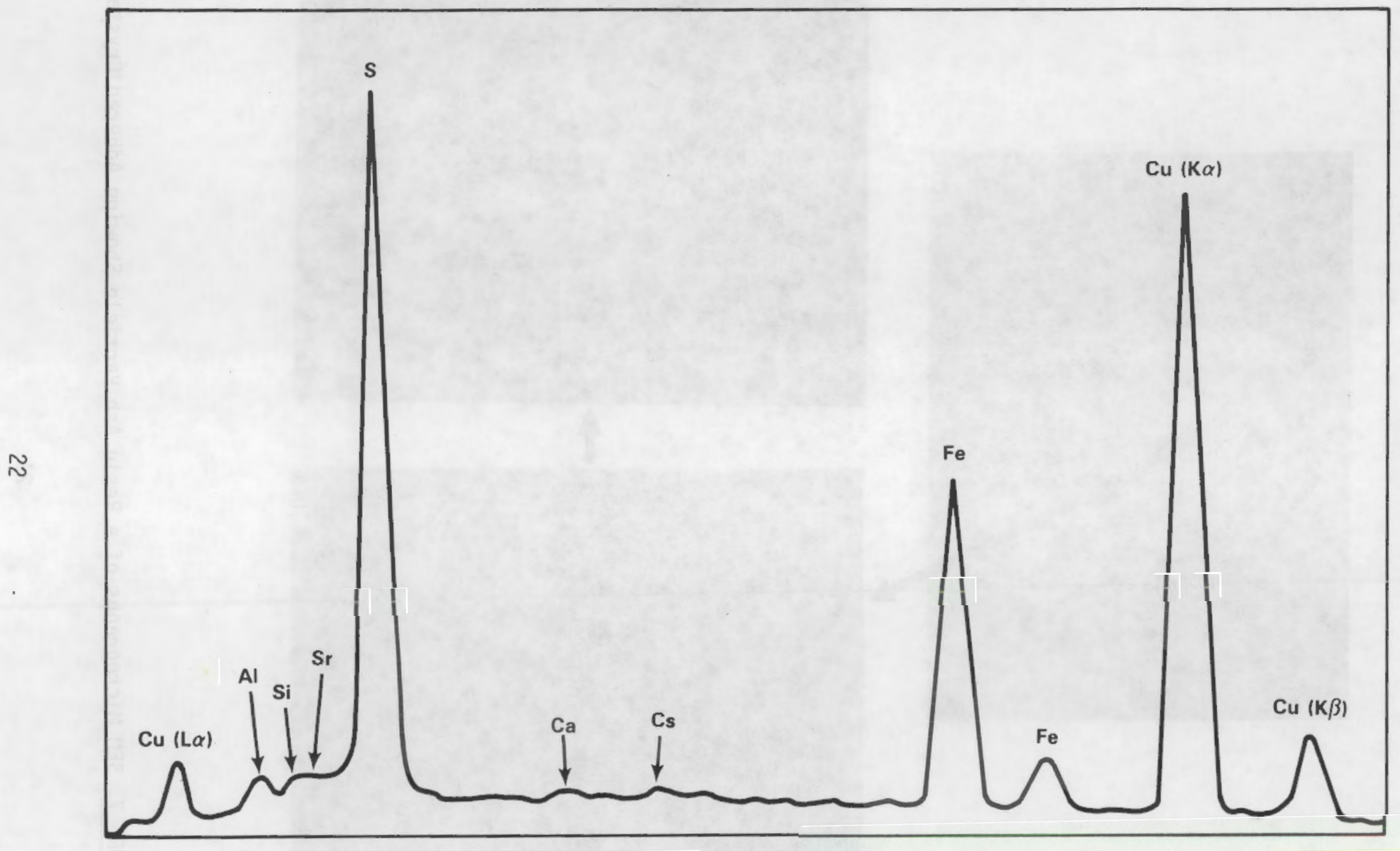

FIGURE 8. EDAX Spectra of Typical Resin Ash Particle 
TABLE 4. Oxide Composition of As-Received and Calcined Trash Ash, Resin Ash, and Ball-Milled Blended Ash Determined by ICP and AA Analysis

\begin{tabular}{|c|c|c|c|c|c|c|}
\hline \multirow[b]{2}{*}{ Oxide $(a)$} & \multicolumn{2}{|c|}{ Trash Ash } & \multicolumn{2}{|c|}{ Resin Ash } & \multicolumn{2}{|c|}{ Blended Ash (b) } \\
\hline & As-Received & Calcined & As-Received & Calcined & As-Received & Calcined \\
\hline $\mathrm{Al}_{2} \mathrm{O}_{3}$ & 20.3 & 32.3 & 0.18 & 0.27 & 8.73 & 15.8 \\
\hline $\mathrm{B}_{2} \mathrm{O}_{3}$ & -- & 0.05 & 0.04 & 0.04 & 0.05 & 0.06 \\
\hline $\mathrm{Ba} 0$ & 0.02 & 0.03 & 0.01 & 0.01 & 0.01 & 0.03 \\
\hline $\mathrm{CaO}$ & 5.45 & 8.98 & 0.36 & 0.51 & 2.25 & 4.22 \\
\hline $\mathrm{Co}_{2} \mathrm{O}_{3}$ & 0.21 & 0.36 & 0.69 & 0.94 & 0.49 & 0.90 \\
\hline $\mathrm{Cr}_{2} \mathrm{O}_{3}$ & 0.04 & 0.05 & 0.04 & 0.05 & 0.03 & 0.06 \\
\hline CuO & 0.13 & 0.31 & 10.3 & 12.5 & 5.81 & 10.4 \\
\hline $\mathrm{Fe}_{2} \mathrm{O}_{3}$ & 0.94 & 1.32 & 40.1 & 53.4 & 20.6 & 35.9 \\
\hline $\mathrm{K}_{2} \mathrm{O}$ & 0.8 & 1.71 & - & -- & 0.5 & 0.7 \\
\hline Mg0 & 0.57 & 1.08 & 0.08 & 0.13 & 0.24 & 0.51 \\
\hline $\mathrm{Na}_{2} \mathrm{O}$ & 0.7 & 1.1 & 0.28 & 0.3 & 0.6 & 0.6 \\
\hline $\mathrm{P}_{2} \mathrm{O}_{5}$ & 0.5 & 1.0 & -- & -- & 0.2 & 0.4 \\
\hline $\mathrm{SiO}_{2}$ & 25.1 & 41.0 & 0.72 & 1.0 & 11.3 & 20.7 \\
\hline Sro & 0.11 & 0.17 & 0.24 & 0.39 & 0.19 & 0.37 \\
\hline $\mathrm{TiO}_{2}$ & 1.58 & 2.55 & 0.05 & 0.04 & 0.68 & 1.24 \\
\hline Zno & 0.08 & 0.40 & 0.07 & 0.1 & 0.08 & 0.13 \\
\hline $\mathrm{ZrO}_{2}$ & -. & -- & 0.01 & 0.03 & $0.21(c)$ & $0.24(c)$ \\
\hline $\mathrm{Cs}_{2} \mathrm{O}$ & 0.021 & 0.036 & 0.071 & 0.12 & 0.047 & 0.10 \\
\hline COTAL & 56.55 & 92.45 & 53.24 & 69.83 & 52.02 & 91.73 \\
\hline
\end{tabular}

(a) Oxidation state is assumed.

(b) Resin and trash ash were mixed in a 325:268 weight ratio, in accordance with the mass of each type of ash collected.

(c) Values are high due to contamination from the zirconia grinding media. 


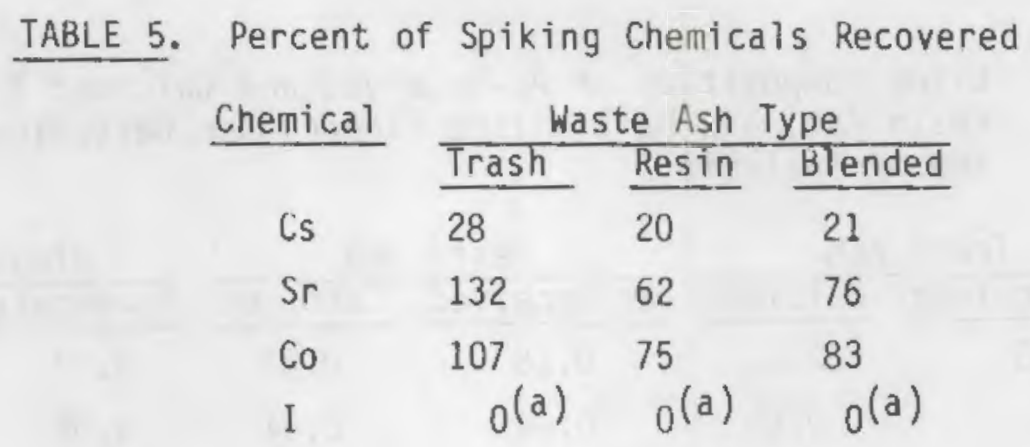

(a) Iodine was below detection limit in all samples.

As previously stated, $\mathrm{Fe}_{2} \mathrm{O}_{3}$ and $\mathrm{Cu} 0$ were added to the resin waste to simulate crud. The amounts of each of those compounds retained in the resin ash were 81 and $84 \%$, respectively. These data are similar to the strontium and cobalt retentions in resin ash, which suggests that approximately $20 \%$ of the resin ash was lost due to factors such as entrainment in the off gas and adherence to the incinerator walls.

\section{ASH CLINKERS}

The clinkers, which were separated from the bulk ash by sieving through a $0.6 \mathrm{~cm}(1 / 4 \mathrm{in.})$ screen, comprised $12 \mathrm{wt} \%$ of the ash produced. Clinkers up to $20 \mathrm{~cm}$ ( $8 \mathrm{in.}$ ) long and $5 \mathrm{~cm}$ (2 in.) thick were recovered. To ensure that jamming of the cement and bitumen mixing systems would not occur when producing waste forms and to ensure that small representative waste forms would be made, clinkers were removed from the bulk ash. The same precaution would be necessary when operating an actual waste solidification system. Hence, a method of treating clinkers for disposal would be required. Possible methods include:

- directly disposing in drums

- washing to remove dust, drying, and then disposal

- grinding and solidifying, as with fine ash

- casting cement or bitumen around clinkers.

Analyses conducted to evaluate the suitability of clinkers for disposal are discussed below.

\section{Appearance}

Clinkers were very "sooty" because fine particles adhered to their surfaces. By rinsing the clinkers on a 20 mesh screen, we collected 4 wt\% as "fines" in the rinse solution. This high fines content presents a dust dispersion concern.

Photos of two typical, large ( 8 $\mathrm{cm}$ or $3 \mathrm{in.}$ dia.) clinkers are shown in Figure 9. The clinker on the right originated from the combustion of trash (paper, plastic, rubber, cloth, and wood). Its surface is shiny blue and very porous. The clinker on the left originated from the combustion of $i$ on exchange resins. It is grey-to-black and its surface is grainy. 
Density

The densities and open porosities of three clinkers were determined (see Figure 10). Clinker $A$ was produced during the incineration of resin waste, and Clinkers $B$ and $C$ were produced during the incineration of trash. The clinkers were cleaned in water with ultrasonic agitation to remove fines and then dried. After weighing, the materials were immersed in water under a vacuum to saturate the open pores with water. The saturated samples were weighed, and then reweighed suspended in water. The calculated apparent density and open

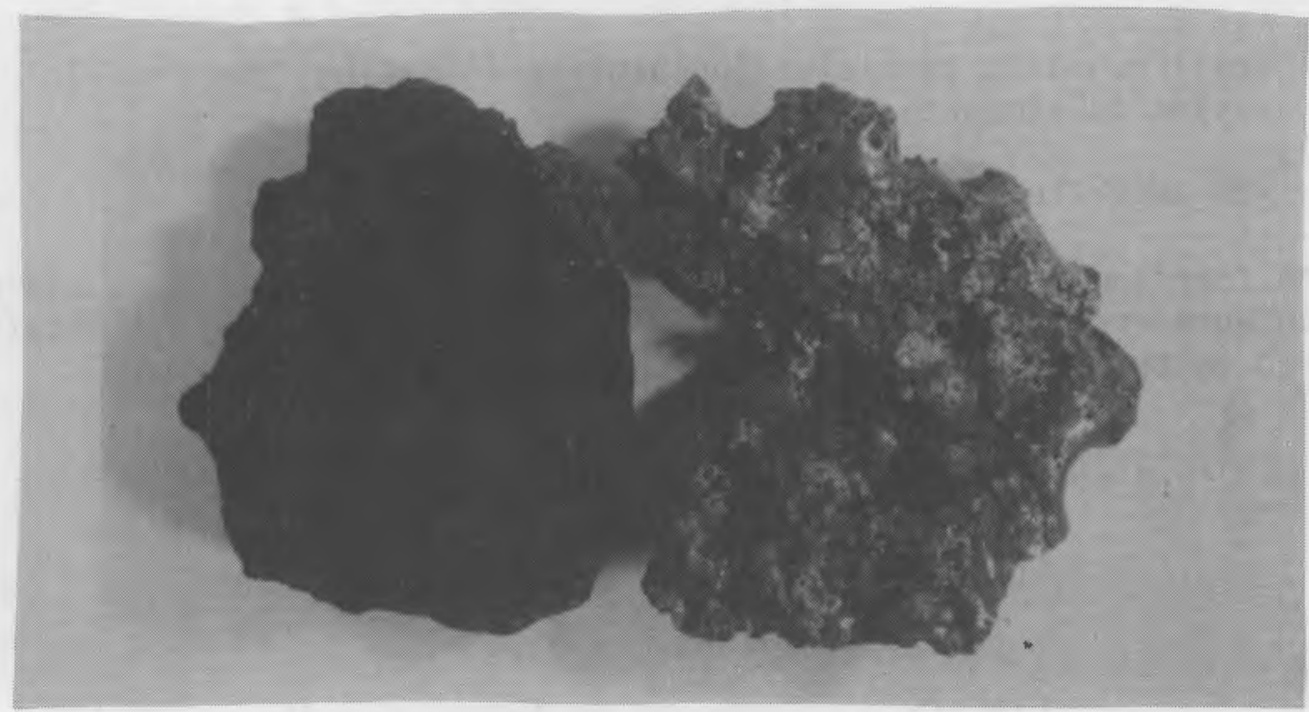

FIGURE 9. Typical, Large Ash Clinkers

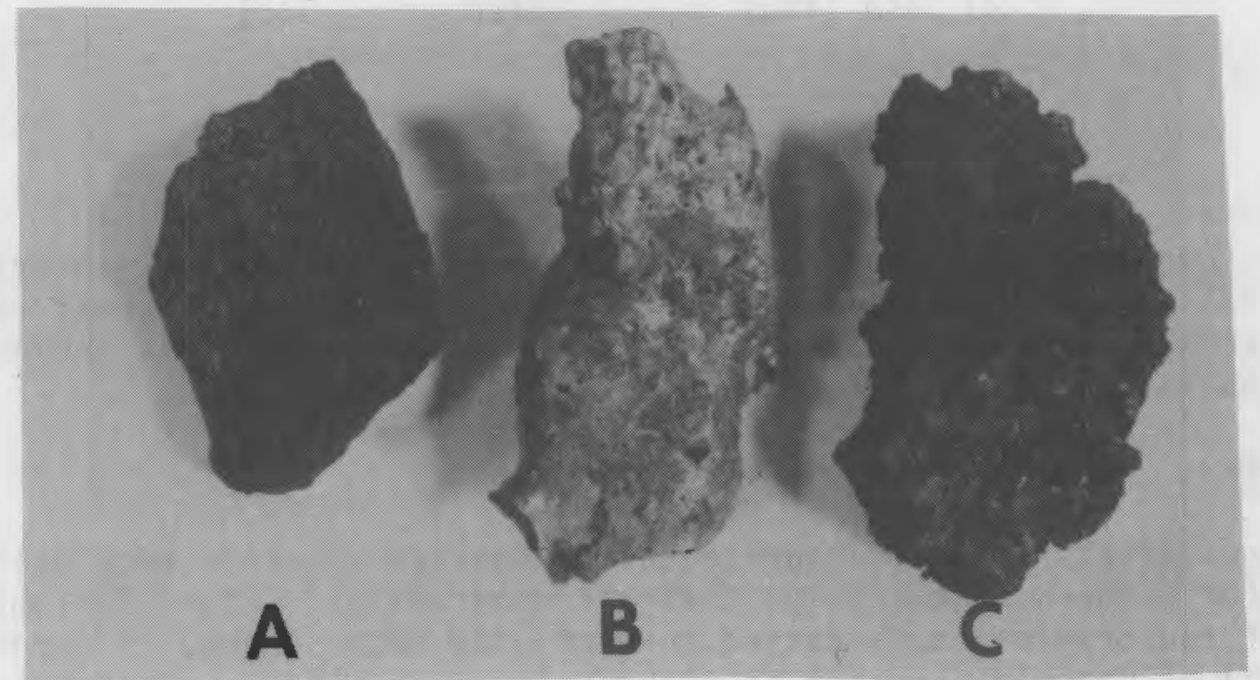

FIGURE 10. Types of Clinkers Used for Density Measurements

porosity of clinkers $A, B$, and C were $1.53 \mathrm{~g} / \mathrm{cm}^{3}$ and $42 \%, 1.34 \mathrm{~g} / \mathrm{cm}^{3}$ and $29 \%$, and $2.44 \mathrm{~g} / \mathrm{cm}^{3}$ and $18 \%$, respectively. 
The bulk density of grab samples of clinkers ranged from 0.5 to $0.6 \mathrm{~g} / \mathrm{cm}^{3}$ or 240 to $2901 \mathrm{~b}$ per $210 \mathrm{~L}$ ( $55 \mathrm{gal}$ ) drum.

\section{Calcination}

Clinkers were separated into sample categories as follows:

- wood chip charcoal

- cinders

- small magnetic particles (probably originating from iron in resins to simulate crud)

- -20 mesh fines.

The four samples were calcined in air at $800^{\circ} \mathrm{C}$ for 18 hours and weighed, and then were recalcined at $1100^{\circ} \mathrm{C}$ for 18 hours and reweighed. Results are tabulated below:

\begin{tabular}{|c|c|c|}
\hline Clinker Category & $\begin{array}{l}\text { Wt\% Loss } \\
\text { at } 800^{\circ} \mathrm{C}\end{array}$ & $\begin{array}{l}\text { Wt\% Loss } \\
\text { at } 1100^{\circ} \mathrm{C}\end{array}$ \\
\hline$\overline{\text { Wood chip charcoal }}$ & 98.6 & $\mathrm{NO}(\mathrm{a})$ \\
\hline Cinders & 1.1 & 1.1 \\
\hline Magnetic particles & 2.2 & 2.8 \\
\hline-20 mesh fines & 31.0 & 33.1 \\
\hline
\end{tabular}

(a) not determined

For comparison, the bulk ash (after screening to remove clinkers) lost $41.8 \%$ of its weight when calcined at $800^{\circ} \mathrm{C}$. It appears from these results that the clinkers, except wood chip charcoal, are essentially fully incinerated and require no further thermal treatment.

Friability

Approximately $100 \mathrm{~g}$ of representative smaller clinkers were ball-milled in alcohol for 6 hours to determine their "crushability." After ball-milling, $56 \mathrm{wt} \%$ of the original mass passed through a 20 mesh screen. A large fraction ( 40 vol\%) of material greater than about $2 \mathrm{~mm}$ was wood chips that failed to be reduced because the wood clinkers floated above the balls. Dry, mechanical comminution techniques, however, would easily reduce the wood chips, since they are totally charred and thus crush quite easily. The remaining clinkers, greater than $5 \mathrm{~mm}$, appear to be of the same type and are very tough. However, they did break up when ground using a mortar and pestle. It appears, therefore, that mechanical crushing by a roller mill or disc mill would reduce 
the size of clinkers sufficiently to allow their incorporation into either cement or bitumen. Provision must still be made for separating out metals and other tough materials which would jam the solidification process.

\section{Leaching}

Leaching tests were conducted on the clinker samples listed below to provide data for assessing the potential of direct disposal of washed and unwashed clinkers:

- grab sample (200 g)

- grab sample washed with water and dried before leaching

- 6 individual clinkers ( 3 washed and 3 as received; see Figure 11)

- -20 mesh fines removed from surfaces of clinkers.

We could not measure the sample surface areas because of their highly irregular geometries. Therefore leaching was conducted at a constant samplemass-to-leachant-volume ratio of $100 \mathrm{~g} / \mathrm{L}$. Samples were leached at $90^{\circ} \mathrm{C}$ under static conditions for 14 days. Deionized water served as the leachant.

Following leaching, the leachates were filtered through a $0.22 \mu \mathrm{m}$ membrane and the $\mathrm{pH}$ was measured as shown in Table 7 . The $\mathrm{pH}$ values of the fines leachate and unwashed clinker leachates are considerably lower than those of the washed samples. The leachate $\mathrm{pH}$ values of the fines and the as-received composite clinkers are the same $(\mathrm{pH}=4.6)$, suggesting that the fines are the main factor in controlling solution $\mathrm{pH}$.

Following leaching the various leachates and clinker samples were analyzed by Inductively Coupled Plasma Emission Spectrometry (ICP). Results are shown in Tables 8 and 9.

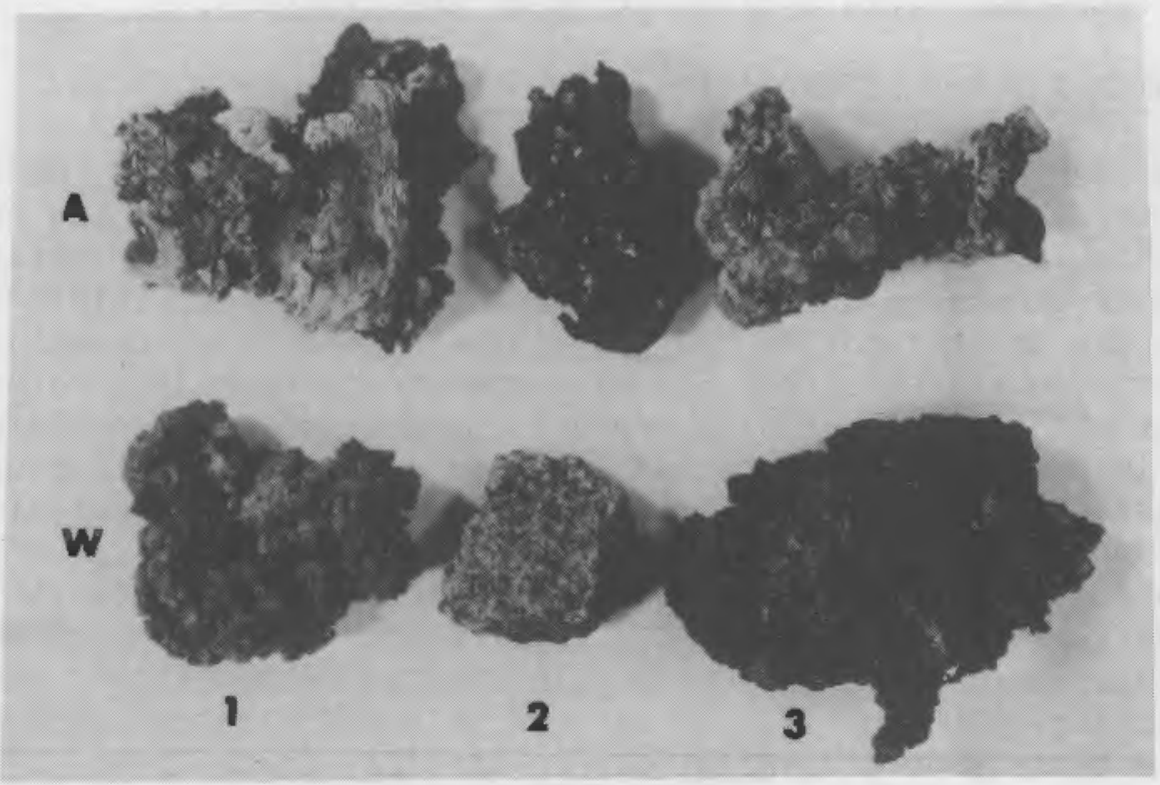

FIGURE 11. Individual Clinkers Subjected to Static, $90^{\circ} \mathrm{C}$ Leach Tests

$$
\begin{aligned}
& A=\text { as received }, \\
& W=\text { washed }
\end{aligned}
$$


TABLE 7. Leachate $\mathrm{pH}$ Values After Leaching Various Ash Clinkers for 14 Days at $90^{\circ} \mathrm{C}$

\begin{tabular}{lccc}
\multicolumn{1}{c}{ Sample } & \multicolumn{2}{c}{$\mathrm{pH}$} \\
\cline { 1 - 1 } $200 \mathrm{~g}$ grab sample & 4.60 & As Received \\
Individual 1 & 5.75 & 5.73 \\
Individual 2 & 6.74 & 7.73 \\
Individual 3 & 5.25 & 9.80 \\
Fines & 4.60 & 7.64
\end{tabular}

The extent of dissolution of the nine samples tested appears to be dependent on the amount of small particles present which possess a high composite surface area. This is evidenced by comparing the washed and asreceived clinkers. For example, the total ion content in solution from leaching the washed grab sample is $68 \%$ less than from leaching the as-received grab sample. However, $\mathrm{pH}$ also appears to have a pronounced effect on dissolution. The two samples that had the highest concentrations of ions in solution (fines and the as-recieved grab sample) also had the lowest leachate $\mathrm{pH}(4.6)$. The low $\mathrm{pH}$ of these solutions resulted in relatively high $\mathrm{Fe}$ concentrations in solution $(>6 \mathrm{mg} / \mathrm{L})$, whereas solutions with a $\mathrm{pH}$ of greater than 5.75 had less than the detection limit $(0.005 \mathrm{mg} / \mathrm{L})$. These $10 \mathrm{w}$ pH values may be of concern when considering direct placement of unwashed clinkers and even bulk ash in steel drums because of the possibilities of enhanced container corrosion rates and overall dissolution of the clinkers.

DISCUSSION OF ASH CHARACTERIZATION RESULTS

The presence of clinkers and the high carbon content in the ashes indicate that this study's incineration was not typical of that expected of an ideally-controlled CAI system. The ashes produced probably represent those that would be generated when the bulk density of the combustible wastes is too high, when the incinerator is charged at too high a rate, or when the incinerator is operated at too low an oxygen content or temperature. In spite of the best efforts to control a process, periods of poor operation periodically occur. Hence, the ash produced in this study is probably representative of ash that will occasionally be produced. Certainly the chemical composition of the ash (except for carbon) is typical of the expected average composition. However, because the applied incinerator will be charged with a wide variety of materials that will not always be well-blended, the ashes produced will vary considerably in chemical composition, including carbon content. Solidifying agents, such as concrete and bitumen, must be able to accommodate these expected variations in chemical composition. The results of the characterization of solidified ashes will be presented in a subsequent report. However, preliminary results indicate that the high-carbon ash produced in this study can be satisfactorily solidified in portland cement and bitumen. 
TABLE 8. Concentration of Ions in Solution After Leaching 14 Days at $90^{\circ} \mathrm{C}$ in D.I. Water

\begin{tabular}{|c|c|c|c|c|c|c|c|c|c|}
\hline \multirow[b]{2}{*}{ Ion } & \multicolumn{9}{|c|}{ Concentration in Solution } \\
\hline & GS-A (a) & GS-W(a) & $A-1(a)$ & $w-1(a)$ & $A-2^{(a)}$ & $w-2(a)$ & $A-3(a)$ & $w-3(a)$ & Fines (a) \\
\hline $\mathrm{Al}$ & 0.72 & --(b) & 0.03 & 0.03 & 0.05 & 1.47 & 0.34 & 0.05 & 0.31 \\
\hline B & 1.11 & 0.74 & 0.08 & 0.07 & 0.04 & 0.01 & 0.48 & 0.07 & 2.30 \\
\hline $\mathrm{Ba}$ & 0.04 & 0.14 & 0.15 & 0.01 & 0.08 & -- & 0.06 & 0.07 & 0.05 \\
\hline $\mathrm{Ca}$ & 127 & 49.6 & 24.3 & 3.98 & 14.6 & 17.9 & 228 & 5.31 & 508 \\
\hline Co & 5.27 & 0.18 & 4.13 & 0.06 & 0.64 & -- & 18.6 & 0.05 & 60.1 \\
\hline $\mathrm{Cu}$ & 0.69 & 0.23 & 5.76 & -- & 0.11 & - & 57.1 & -- & 3.21 \\
\hline $\mathrm{Fe}$ & 7.10 & 0.17 & -- & -- & -- & -- & -- & -- & 6.15 \\
\hline $\mathrm{k}$ & 88.0 & 20.8 & 2.37 & 1.43 & 2.26 & 2.75 & 72.9 & 8.74 & 56.0 \\
\hline Li & 0.21 & 0.08 & 0.03 & 0.02 & 0.03 & 0.09 & 0.66 & 0.06 & 0.46 \\
\hline Mg & 13.1 & 3.51 & 3.23 & 0.66 & 1.80 & 0.03 & 26.0 & 0.78 & 92.4 \\
\hline Mn & 2.98 & 0.45 & 0.11 & 0.01 & 0.05 & -- & 1.31 & -- & 5.45 \\
\hline $\mathrm{Na}$ & 69.6 & 9.02 & 2.29 & 1.07 & 2.46 & 2.40 & 96.7 & 3.74 & 63.7 \\
\hline $\mathrm{Ni}$ & 0.09 & 0.04 & 0.04 & -- & 0.03 & -- & 0.24 & - & 0.10 \\
\hline Si & 88.7 & 33.7 & 19.6 & 9.07 & 12.2 & 0.17 & 57.1 & 16.7 & 110 \\
\hline $\mathrm{Sr}$ & 11.3 & 15.0 & 3.94 & 0.55 & 1.90 & 0.12 & 9.02 & 0.83 & 12.2 \\
\hline $\mathrm{Zn}$ & 1.38 & 0.04 & 0.43 & -- & 0.08 & - & 3.15 & -- & 4.36 \\
\hline Cs & 6.30 & 1.80 & 1.10 & 0.28 & 0.56 & 0.22 & 4.50 & 0.43 & 22.5 \\
\hline $\mathrm{pH}$ & 4.60 & 5.73 & 5.75 & 7.73 & 6.74 & 9.80 & 5.25 & 7.64 & 4.60 \\
\hline
\end{tabular}

(a) $G S=$ grab sample, $A=$ as received, $W=$ washed (see Table 7 ).

(b) Below the detection limit (typical). 
TABLE 9. Oxide Composition of Individual Clinkers and Fines After Leaching

\begin{tabular}{|c|c|c|c|c|c|c|c|}
\hline \multirow[b]{2}{*}{ Oxide } & \multicolumn{7}{|c|}{ Composition, wt\% (a) } \\
\hline & $A-1(b)$ & $w-1(b)$ & $A-2^{(b)}$ & $W-2^{(b)}$ & $A-3(b)$ & $W-3^{(b)}$ & FINES $(\mathrm{b})$ \\
\hline $\mathrm{Al}_{2} \mathrm{O}_{3}$ & 32.25 & 33.25 & 30.25 & 43.10 & 30.30 & 26.15 & 15.60 \\
\hline $\mathrm{B}_{2} \mathrm{O}_{3}$ & 0.09 & 0.12 & 0.07 & 0.11 & 0.11 & 0.19 & 0.15 \\
\hline $\mathrm{BaO}$ & 0.03 & 0.03 & 0.03 & 0.03 & 0.04 & 0.21 & 0.02 \\
\hline $\mathrm{CaO}$ & 8.17 & 9.11 & 5.78 & 5.81 & 9.43 & 14.35 & 2.76 \\
\hline $\mathrm{Co}_{2} \mathrm{O}_{3}$ & 0.39 & 0.17 & 0.03 & -- & 0.15 & 1.78 & 0.39 \\
\hline $\mathrm{Cr}_{2} \mathrm{O}_{3}$ & 0.04 & 0.04 & -- & -- & 0.06 & -- & -- \\
\hline CuO & 0.27 & 0.24 & 0.23 & 0.24 & 0.99 & 0.39 & 5.13 \\
\hline $\mathrm{Fe}_{2} \mathrm{O}_{3}$ & 1.00 & 0.81 & 1.96 & 1.13 & 2.18 & 0.98 & 15.65 \\
\hline $\mathrm{K}_{2} \mathrm{O}$ & 0.64 & 1.30 & 0.92 & -- & 2.00 & 2.10 & -- \\
\hline $\mathrm{LiO}_{2}$ & 0.03 & 0.02 & -- & -- & 0.02 & 0.03 & -- \\
\hline $\mathrm{MgO}$ & 0.60 & 0.46 & 0.33 & 0.24 & 0.86 & 1.25 & 0.27 \\
\hline $\mathrm{MnO}_{2}$ & 0.02 & 0.02 & 0.05 & 0.03 & 0.03 & 0.04 & 0.02 \\
\hline $\mathrm{Na}_{2} \mathrm{O}$ & -- & 0.04 & -- & -- & 0.69 & 0.25 & -- \\
\hline $\mathrm{P}_{2} \mathrm{O}_{5}$ & -- & 0.49 & 1.37 & -- & 0.77 & 7.30 & -- \\
\hline $\mathrm{SiO}_{2}$ & 38.65 & 39.25 & 23.10 & 30.10 & 35.00 & 31.40 & 18.30 \\
\hline Sro & 0.22 & 0.11 & 0.04 & 0.02 & 0.10 & 0.85 & 0.14 \\
\hline $\mathrm{TiO}_{2}$ & 2.25 & 2.01 & 0.80 & 0.96 & 2.58 & 2.29 & 1.00 \\
\hline $\mathrm{ZnO}$ & -- & -- & 0.08 & -- & 0.09 & 0.06 & 0.11 \\
\hline $\mathrm{ZrO}_{2}$ & 0.38 & 0.03 & 0.01 & 0.08 & 0.05 & -- & 0.04 \\
\hline $\mathrm{Cs}_{2} \mathrm{O}$ & 0.06 & 0.03 & 0.02 & 0.02 & 0.03 & 0.06 & 0.02 \\
\hline TOTALS & 85.09 & 87.53 & 65.37 & 81.87 & 85.48 & 89.68 & 59.60 \\
\hline
\end{tabular}

(a) Determined by average from $\mathrm{KOH} / \mathrm{Ni}$ and $\mathrm{Na}_{2} \mathrm{O}_{2} / \mathrm{Zr}$ fusion and ICP analysis. (b) $A=$ as received, $W=$ washed (see Table 7 ). 
Although the ashes were not hygroscopic, they exhibited an acidic $\mathrm{pH}$ when water was added. This may signal a corrosion concern if hygroscopic materials are allowed to come into contact with the combustibie materials during plant operations or if water is inadvertently added to stored ashes.

Analyses of "crud" and spiking materials in the ashes yielded somewhat confusing results. However, it can be confidently concluded that most of the cesium vaporized from the burning waste and virtually all of the iodine escaped. It is assumed that these waste components would be captured in the incinerator off-gas system and processed in the ash solidification system.

Clinkers generally were well-incinerated (i.e., they contained a low content of volatile chemicals). This suggests that further incineration will not reduce their quantity appreciably. Clinkers heated to $1100^{\circ} \mathrm{C}$ did not become a powder. Therefore, pneumatic methods of removing ash from an incinerator may not be successful, as clinkers would not be easily transported. Mechanical crushing of clinkers to allow them to be fed to the ash solidification process appears feasible. However, before this is done, tramp metals and other tough materials that might jam the process must be removed. Washing clinkers removes most of the dust that would be dispersible in a handling accident. However, the leach resistance of washed clinkers does not appear to be much greater than that of the fine ash. Because they are somewhat leachable and easy to crush, clinkers may not be well-suited to shallow land burial. Better methods of treatment include crushing and solidifying them with fine ash and directly incorporating them into a solidifying matrix. 


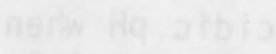

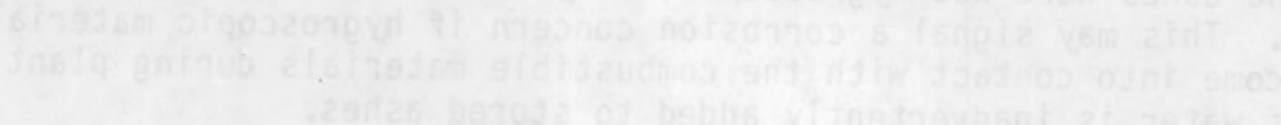

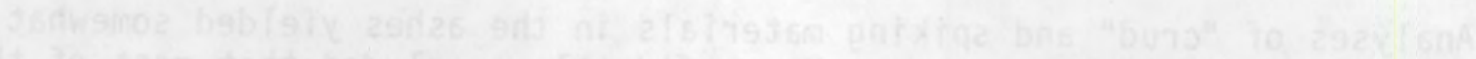

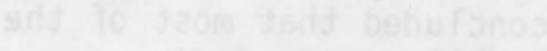

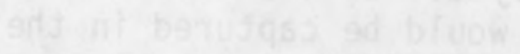

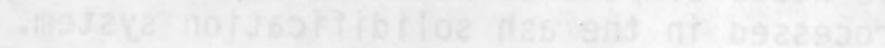

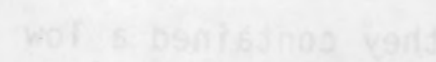

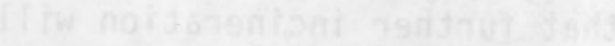

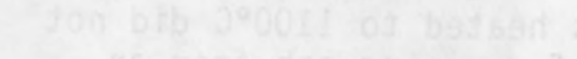

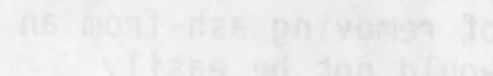

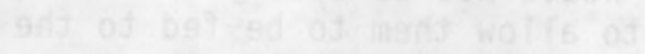

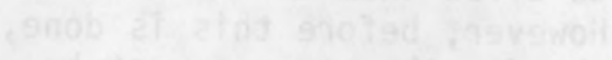

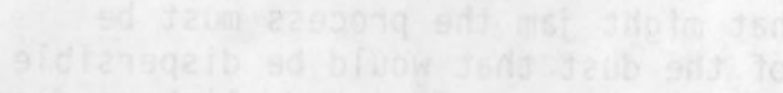

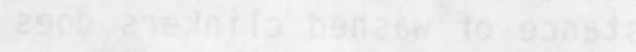

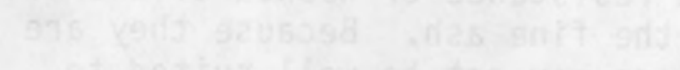

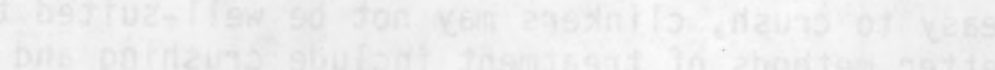

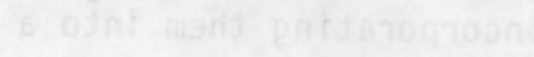




\section{REFERENCES}

Borduin, L. C. and A. L. Taboas. 1981. "DOE Radioactive Waste Incineration Technology." Nuclear Safety 22(1): 56-69.

Colombo, P. and R. M. Neilson, Jr. 1979. Properties of Radioactive Wastes and Waste Containers: First Topical Report. NUREG/CR-0619 (BNL-NUREG-50957), Brookhaven National Laboratory, Upton, New York.

DiSibio, R. R. 1980. "Low-Level Waste Policy Needs from a Regional

Perspective." In Proceedings of the Symposium on Waste Management, University of Arizona, Tucson, Arizona.

Licensing Requirements for Land Disposal of Radioactive Waste, 10 C.F.R. Part 61 (1978).

Osmeyer, W. E. 1980. "Operational Cost Comparisons for Various Radwaste Disposal Techniques." In Transactions of the American Nuclear Society Annual Meeting, ed. R. Farmakes, Pp. 86-87. TRANSA035 1-676, American Nuclear Society, Inc., LaGrande Park, Illinois.

U. S. Department of Energy. 1979. Technology for Commercial Radioactive Waste Management. D0E/ET-0028, Pacific Northwest Laboratory, Richland, Washington. 

APPENDIX A

INCINERATOR OPERATING CONDITIONS FOR RESIN WASTE 
TABLE A.1. Incinerator Operating Conditions for Run 1 (Sheet 1 of 4)

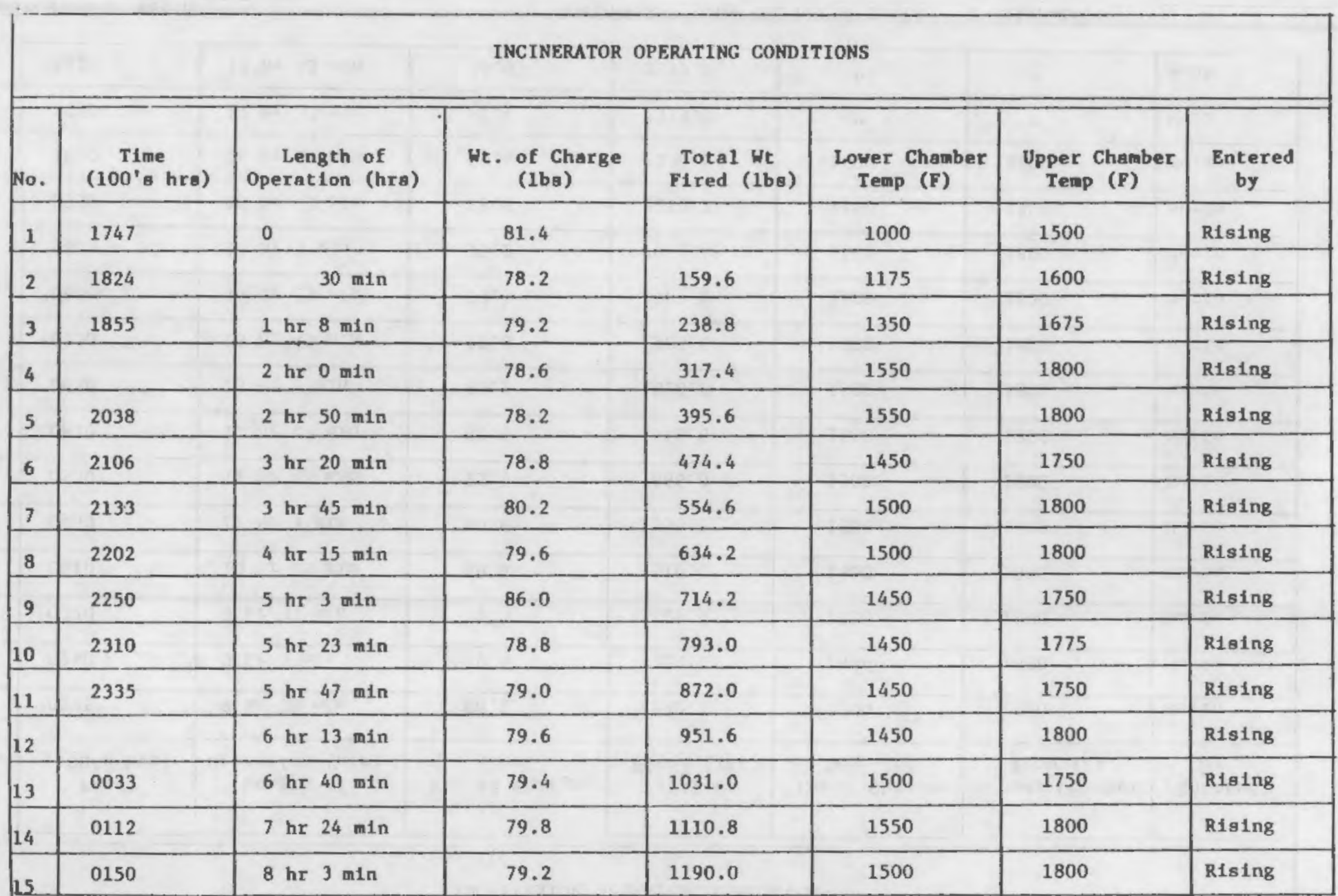

WASTE TYPE Resin

AVERAGE CHARGING RATE. 148

AVERAGE UPPER CHAMBER TEMP 1743.3

AVERAGE. LOWER CHAMBER TEHP 1428.3
ENGINEER - name Bruce Rlging___; slgnature

TRCTINICIAN - name John Faught

- elgnature 
TABLE A.1. Incinerator Operating Conditions for Run 1 (Sheet 2 of 4 )

\begin{tabular}{|c|c|c|c|c|c|c|c|}
\hline \multicolumn{8}{|c|}{ INCINERATOR OPERATING CONDITIONS } \\
\hline No. & $\begin{array}{c}\text { Time } \\
\left(100^{\prime} \mathrm{g} \text { hrg }\right)\end{array}$ & $\begin{array}{c}\text { Length of } \\
\text { Operation (hrs) }\end{array}$ & $\begin{array}{l}\text { Wt. of Charge } \\
\text { (1bs) }\end{array}$ & $\begin{array}{l}\text { Total Wt } \\
\text { Fired (1bs) }\end{array}$ & $\begin{array}{c}\text { Lower Chamber } \\
\text { Temp (F) }\end{array}$ & $\begin{array}{l}\text { Upper Chamber } \\
\text { Temp (F) }\end{array}$ & $\begin{array}{c}\text { Entered } \\
\text { by }\end{array}$ \\
\hline 1 & 0225 & $8 \mathrm{hr} 38 \mathrm{~min}$ & 80.2 & 1270.2 & 1500 & 1800 & Murin \\
\hline 2 & 0250 & $9 \mathrm{hr} 3 \mathrm{~min}$ & 80.4 & 1350.6 & 1500 & 1800 & Murin \\
\hline 3 & 0320 & $9 \mathrm{hr} 33 \mathrm{mln}$ & 79.0 & 1429.6 & 1500 & 1800 & Murin \\
\hline 4 & 0410 & $10 \mathrm{hr} 23 \mathrm{~min}$ & 80.4 & 1510.0 & 1500 & 1800 & Murin \\
\hline 5 & 0450 & $11 \mathrm{hr} 3 \mathrm{~min}$ & 80.6 & 1590.6 & 1500 & 1800 & Murin \\
\hline 6 & 0530 & $11 \mathrm{hr} 43 \mathrm{~min}$ & 75.4 & 1666.0 & 1500 & 1800 & Murin \\
\hline 7 & 0610 & $12 \mathrm{hr} 23 \mathrm{~min}$ & 80.6 & 1746.6 & 1500 & 1800 & Murin \\
\hline 8 & 0650 & $13 \mathrm{hr} 3 \mathrm{~min}$ & 80.2 & 1826.8 & 1500 & 1800 & Murin \\
\hline 9 & 0730 & $13 \mathrm{hr} 43 \mathrm{~min}$ & 78.8 & 1905.6 & 1500 & 1800 & Murin \\
\hline 10 & 0810 & $14 \mathrm{hr} 23 \mathrm{~min}$ & 77.6 & 1983.2 & 1500 & 1800 & Mur1n \\
\hline 11 & 0850 & $15 \mathrm{hr} 3 \mathrm{~min}$ & 78.2 & 2071.4 & 1500 & 1800 & Murin \\
\hline 12 & 0930 & $15 \mathrm{hr} 43 \mathrm{~min}$ & 78.8 & 2150.2 & 1500 & 1800 & Mur1n \\
\hline 13 & 1010 & $16 \mathrm{hr} 23 \mathrm{~m} 1 \mathrm{n}$ & 80.4 & 2230.6 & 1500 & 1800 & Mur1n \\
\hline 14 & 1050 & $17 \mathrm{hr} \quad 3 \mathrm{~min}$ & 87.4 & 2313.0 & $"$ & $"$ & Webb \\
\hline 15 & 1130 & $17 \mathrm{hr} 43 \mathrm{~min}$ & 79.0 & 2392.0 & $"$ & $"$ & Webb \\
\hline
\end{tabular}

WASTE TYPE Resin

AVERACE CIIARGING RATE $125 \mathrm{lbs} / \mathrm{hr}$ AVERAGE UPPER CHAMBER TEHP 1800 "TERAGR. LOWER CILMMER TEMT 1500
ENGINEER - name Jeannette Murin TECHNICIAN - name Ear1 Cox

; signature

; signature 
TABLE A.1. Incinerator Operating Conditions for Run 1 (Sheet 3 of 4)

\begin{tabular}{|c|c|c|c|c|c|c|c|}
\hline \multicolumn{8}{|c|}{ INCINERATOR OPERATING CONDITIONS } \\
\hline No. & $\begin{array}{c}\text { Time } \\
\left(100^{\prime} \text { 's hrs }\right)\end{array}$ & $\begin{array}{c}\text { Length of } \\
\text { Operation (hrs) }\end{array}$ & $\begin{array}{l}\text { Wt. of charge } \\
\text { (1bg) }\end{array}$ & $\begin{array}{l}\text { Total Wt } \\
\text { Fired (1bs) }\end{array}$ & $\begin{array}{c}\text { Lower Chamber } \\
\text { Temp }(\boldsymbol{F})\end{array}$ & $\begin{array}{c}\text { Upper Chamber } \\
\text { Temp (F) }\end{array}$ & $\begin{array}{c}\text { Entered } \\
\text { by }\end{array}$ \\
\hline 1 & 1210 & $18 \mathrm{hr} 23 \mathrm{~min}$ & 80.4 & 2472.4 & 1500 & 1800 & Webb \\
\hline 2 & 1250 & $19 \mathrm{hr} 3 \mathrm{~min}$ & 78.8 & 2551.2 & 1500 & 1800 & Hupp \\
\hline 3 & 1330 & $19 \mathrm{hr} 43 \mathrm{~min}$ & 80.8 & 2632.0 & 1500 & 1800 & Webb \\
\hline 4 & 1410 & $20 \mathrm{hr} 23 \mathrm{~min}$ & 78.6 & 2710.6 & 1500 & 1800 & Webb \\
\hline 5 & 1450 & $21 \mathrm{hr} 3 \mathrm{~min}$ & 79.4 & 2790.0 & 1500 & 1800 & Hupp \\
\hline 6 & 1530 & $21 \mathrm{hr} 23 \mathrm{~min}$ & 79.4 & 2869.4 & 1500 & 1800 & Webb \\
\hline 7 & 1610 & $22 \mathrm{hr} 23 \mathrm{~min}$ & 79.8 & 2949.2 & 1500 & 1800 & Webb \\
\hline 8 & 1650 & $23 \mathrm{hr} 3 \mathrm{~min}$ & 80.2 & 3029.4 & 1500 & 1800 & Webb \\
\hline 9 & 1730 & $23 \mathrm{hr} 43 \mathrm{~min}$ & 79.8 & 3109.2 & 1500 & 1800 & Rising \\
\hline 10 & 1800 & $24 \mathrm{hr} 15 \mathrm{~min}$ & 79.8 & 3189.0 & 1500 & 1800 & R1sing \\
\hline 11 & 1830 & $24 \mathrm{hr} 45 \mathrm{~min}$ & 79.6 & 3268.6 & 1500 & 1800 & Rising \\
\hline 12 & 1900 & $25 \mathrm{hr} 15 \mathrm{mln}$ & 81.4 & 3350.0 & 1500 & 1800 & Rising \\
\hline 13 & 1930 & $25 \mathrm{hr} 45 \mathrm{~min}$ & 76.8 & 3426.8 & 1500 & 1800 & Rising \\
\hline 14 & 2010 & $26 \mathrm{hr} 25 \mathrm{~min}$ & 158.2 & 3585.0 & 1500 & 1800 & Rising \\
\hline 1.5 & 2120 & $27 \mathrm{hr} 35 \mathrm{~min}$ & 80.2 & 3665.2 & 1450 & 1800 & Rising \\
\hline
\end{tabular}

WASTE. TYPE RESIn

AVERAGE CHARGING RATE, $129.8 \mathrm{1bs} / \mathrm{hr}$

AVERAGE UPPER CHAMBER TEMP $1800 \mathrm{~F}$

AVERAGE. LOHER CHAMBER TEMP 1496.7
ENCINEER - name P. Webb

TRCINICTAN - name D. Hupp

DATE_ $10 / 10 / 81$
; Bignature

ignature 
TABLE A.1. Incinerator Operating Conditions for Run 1 (Sheet 4 of 4 )

\begin{tabular}{|c|c|c|c|c|c|c|c|}
\hline \multicolumn{8}{|c|}{ INCINERATOR OPERATING CONDITIONS } \\
\hline No. & $\begin{array}{c}\text { Time } \\
\left(100^{\prime} \mathrm{s} \text { hrs }\right)\end{array}$ & $\begin{array}{c}\text { Length of } \\
\text { Operation (hrs) }\end{array}$ & $\begin{array}{l}\text { Wt. of Charge } \\
\text { (1bs) }\end{array}$ & $\begin{array}{l}\text { Total wt } \\
\text { F1red (1bo) }\end{array}$ & $\begin{array}{l}\text { Lower Chamber } \\
\text { Temp (F) }\end{array}$ & $\begin{array}{l}\text { Upper Chamber } \\
\text { Temp (F) }\end{array}$ & $\begin{array}{l}\text { Entered } \\
\text { by }\end{array}$ \\
\hline 1 & 2150 & $28 \mathrm{hr} 5 \mathrm{~min}$ & 80.6 & 3745.8 & 1500 & 1800 & Murin \\
\hline 2 & 2220 & $28 \mathrm{hr} 35 \mathrm{~min}$ & 80.0 & 3825.8 & 1500 & 1800 & Murin \\
\hline 3 & 2250 & $29 \mathrm{hr} 5 \mathrm{~min}$ & 80.2 & 3906.0 & 1500 & 1800 & Murin \\
\hline 4 & 2320 & $29 \mathrm{hr} 35 \mathrm{~min}$ & 79.6 & 3985.6 & 1500 & 1800 & Murin \\
\hline 5 & 2350 & $30 \mathrm{hr} 5 \mathrm{~min}$ & 81.4 & 4067.0 & 1500 & 1800 & Murin \\
\hline 6 & 0150 & $32 \mathrm{hr} 5 \mathrm{~min}$ & 0 & 4067.0 & 1500 & 1800 & Rising \\
\hline 7 & & & & & & & res \\
\hline 8 & & & & & & & \\
\hline 9 & & & & & & & \\
\hline 10 & & & & & & & \\
\hline 11 & & & & & & & \\
\hline 12 & & & & & & & \\
\hline 13 & & & & & & & \\
\hline 14 & & & & & & & \\
\hline 15 & & & & & & & \\
\hline
\end{tabular}

WASTE TYPE Resin.

AVERAGE CHARGING RATE $127.09 .1 \mathrm{~b} / \mathrm{hr}$ AVERAGE UPPER CHUMBER TEMP $1800 \mathrm{~F}$ AVERAGE. LOWER CHAMBER TEMP $1500 \mathrm{~F}$
ENGINEER - name Jeannette Murin

TECINICIAN - name John Faught

DATE_ $10 / 10 / 81$ signature ; signature 
APPENDIX B

INCINERATOR OPERATING CONDITIONS FOR GENERAL TRASH WASTE 
TABLE B.1. Incinerator Operating Conditions for Run 2 (Sheet 1 of 9)

\begin{tabular}{|c|c|c|c|c|c|c|c|}
\hline \multicolumn{8}{|c|}{ INCINERATOR OPERATING CONDITIONS } \\
\hline No. & $\begin{array}{c}\text { Time } \\
\left(100^{\prime} \mathrm{s} \text { hro }\right)\end{array}$ & $\begin{array}{c}\text { Length of } \\
\text { Operation (hrs) }\end{array}$ & $\begin{array}{l}\text { Wt. of Charge } \\
\text { (1bs) }\end{array}$ & $\begin{array}{l}\text { Total Wt } \\
\text { F1red (1bs) }\end{array}$ & $\begin{array}{l}\text { Lower Chamber } \\
\text { Temp (F) }\end{array}$ & $\begin{array}{l}\text { Upper Chamber } \\
\text { Temp (F) }\end{array}$ & $\begin{array}{l}\text { Entered } \\
\text { by }\end{array}$ \\
\hline 1 & 1751 & & no.1 58.4 & 58.4 & 1100 & 1450 & MURIn \\
\hline 2 & 1800 & 9 mins & 47.6 & 106.0 & 1300 & 1600 & if \\
\hline 3 & 1808 & 17 mins & 37.2 & 143.2 & 1250 & 2000 & " \\
\hline 4 & 1815 & $24 \mathrm{mins}$ & 45.4 & 188.6 & 1500 & 1756 & " \\
\hline 5 & 1825 & $3 y$ mins & 28.4 & 217.0 & 1500 & 1750 & I. \\
\hline 6 & 1830 & 39 mise & 39.2 & 256.2 & 1500 & 1750 & " \\
\hline 7 & 1850 & 59 mins & 46.4 & 302.6 & $1400^{\neq \neq}$ & $1700^{* *}$ & ". \\
\hline 8 & 1900 & $1 \mathrm{hr} 9 \mathrm{~mm}$ & 31.2 & 333.8 & 1650 & 1750 & ". \\
\hline 9 & 1925 & $1 \mathrm{hr} 34 \mathrm{~min}$ & 54.4 & 388.2 & 1450 & 1550 & 11 \\
\hline 10 & 1945 & $1 \mathrm{hr} 54 \mathrm{~min}$ & 48.6 & 436.8 & 1420 & 1750 & ". \\
\hline 11 & 2025 & $2 \mathrm{hr} 34 \mathrm{~min}$ & 55.8 & 4926 & 1500 & 700 & 11 \\
\hline 12 & 2050 & $2 \mathrm{hr} 59 \mathrm{~min}$ & 45.6 & 537.6 & 1550 & 1700 & " \\
\hline 13 & 2110 & $3 \mathrm{hr} 19 \mathrm{~min}$ & 430 & 580.6 & 1660 & 1780 & Faught \\
\hline 14 & 2130 & $3 \mathrm{hr} \quad 39 \mathrm{~mm}$ & 46.8 & 627.4 & 1900 & 2200 & 11 \\
\hline 15 & 2150 & $3 \mathrm{hr} 59 \mathrm{~min}$ & $2 \quad 26.0$ & 653.4 & 1775 & 1825 & " \\
\hline
\end{tabular}

HASTE TYPE

ENGINEER - name Jegnaetle Murin : olgnature

AVERAGE CHARGING RATE $164.0 \mathrm{lb} / \mathrm{hr}\left(\frac{653.4}{3 \mathrm{hr} 54 \mathrm{mman}}\right)$ TECHNICIAN - name Joho. Faught_; signature AVERAGE UPPER CHAMBER TEMP 1750.3 AVERAGE LOWER CHAMBER TEMP 1497

DATE $10 / 23 / 81$ 
TABLE B.1. Incinerator Operating Conditions for Run 2 (Sheet 2 of 9)

\section{INCINERATOR OPERATING CONDITIONS}

\begin{tabular}{|c|c|c|c|c|c|c|c|}
\hline No. & $\begin{array}{c}\text { Time } \\
\left(100^{\prime} \mathrm{s} \mathrm{hrs}\right)\end{array}$ & $\begin{array}{c}\text { Length of } \\
\text { Operation (hrs) }\end{array}$ & $\begin{array}{l}\text { Wt. of Charge } \\
\text { (1bs) }\end{array}$ & $\begin{array}{l}\text { Total Wt } \\
\text { F1red (lbs) }\end{array}$ & $\begin{array}{l}\text { Lower Chamber } \\
\text { Temp (F) }\end{array}$ & $\begin{array}{l}\text { Upper Chamber } \\
\text { Temp (F) }\end{array}$ & $\begin{array}{l}\text { Entered } \\
\text { by }\end{array}$ \\
\hline 1 & 2210 & $4 \mathrm{hr} 19$ min & 22.8 & 676.2 & 1820 & 1860 & Favght \\
\hline 2 & 2220 & $4 \mathrm{hr} 29 \mathrm{~min}$ & 286 & -704.8 & 1780 & 1700 & $"$ \\
\hline 3 & 2230 & $4 \mathrm{hr} 39 \mathrm{~min}$ & 51.6 & 756.4 & 1746 & 2300 & " \\
\hline $\mid 4$ & 2300 & $5 \mathrm{hr} 9 \mathrm{~min}$ & 526 & 8090 & 1800 & 2300 & " \\
\hline 5 & 2330 & $5 \mathrm{hr} 39 \mathrm{mn}$ & 30.4 & 839.4 & 1840 & 1890 & " \\
\hline 6 & 2350 & $5 \mathrm{hr} 59 \mathrm{~min}$ & 27.6 & 867.0 & 1700 & 1810 & " \\
\hline 7 & 10 & $6 \mathrm{hr} 19 \mathrm{~min}$ & 420 & 109.0 & 1820 & 2070 & " \\
\hline 8 & 30 & $6 \mathrm{hr} 39 \mathrm{mid}$ & 43.6 & 952.6 & 1750 & 2000 & " \\
\hline 9 & 100 & $7 \mathrm{hr} 9 \mathrm{~min}$ & 30.2 & 982.8 & 1700 & 1800 & " \\
\hline 10 & 115 & $7 \mathrm{hr} 24 \mathrm{~min}$ & 43.6 & 1026.4 & 1710 & 1880 & " \\
\hline 11 & 125 & $7 \mathrm{hr}-34 \mathrm{~min}$ & 27.4 & 1053.8 & 1980 & 1880 & " \\
\hline 12 & 1.45 &. $\mathrm{hr} 54 \mathrm{~min}$ & 48.0 & 1101.8 & 1780 & 2080 & "I \\
\hline 13 & $2: 05$ & $8 \mathrm{hr} 14 \mathrm{~min}$ & 30.2 & 1132.0 & 1800 & 1820 & ". \\
\hline 14 & $2: 30$ & $8 \mathrm{hr} 39 \mathrm{~min}$ & 49.6 & 1181.6 & 1860 & 1680 & " \\
\hline Ls & $2: 45$ & $8 \mathrm{hr} 54 \mathrm{~min}$ & $2^{2} \quad 31.2$ & 1212.8 & 1840 & 2380 & " \\
\hline
\end{tabular}

WASTE TYPE

ENGINEER - name

i signature

AVERAGE CHARGING RATE_117.1 点( $\left.\frac{536.6}{4 \mathrm{hr} 35 \mathrm{~min}}\right)$ TECHNICIAN - name John Fageht ; algnąture AVERAGE UPPER CHAMBER TEMP 1963.4 AVERAGE. LOWER CHAMBER TEMP 1794.7 DATE $10 / 23,24 / 81$ 
TABLE B.1. Incinerator Operating Conditions for Run 2 (Sheet 3 of 9)

\begin{tabular}{|c|c|c|c|c|c|c|c|}
\hline & & & INCINERATOR & PERATING CONDI & IONS & & \\
\hline No. & $\begin{array}{c}\text { T1me } \\
\left(100^{\prime} \mathrm{g} \text { hrs }\right)^{*}\end{array}$ & $\begin{array}{c}\text { Length of } \\
\text { Operation (hrs) }\end{array}$ & $\begin{array}{l}\text { Wt. of Charge } \\
\text { (Ibs) }\end{array}$ & $\begin{array}{l}\text { Total wt } \\
\text { F1red (1bs) }\end{array}$ & $\begin{array}{l}\text { Lower Chamber } \\
\text { Temp }(F)\end{array}$ & $\begin{array}{l}\text { Upper Chamber } \\
\text { Temp (F) }\end{array}$ & $\begin{array}{c}\text { Entered } \\
\text { by }\end{array}$ \\
\hline 1 & $3: 30$ & $9 \mathrm{hr} 39 \mathrm{~min}$ & 47.0 & 1259.8 & 1680 & $2500 t$ & FavGMT \\
\hline 2 & $3: 55$ & $10 \mathrm{hr} 4 \mathrm{~min}$ & 30.2 & 1290.0 & 1650 & T.C. Burnout & " \\
\hline 3 & 4:30 & $10 \mathrm{hr} 39 \mathrm{~min}$ & 47.0 & 1337.0 & 1570 & 1500 & 1 \\
\hline 4 & $4: 42$ & $10 \mathrm{hr} 51 \min$ & 32.2 & 1369.2 & 1480 & 2100 & '. \\
\hline 5 & $5: 00$ & $11 \mathrm{hr} 9 \mathrm{~min}$ & 48.6 & 1417.8 & 1500 & 2100 & ". \\
\hline 6 & $5: 10$ & $11 \mathrm{hr} 19 \mathrm{moln}$ & 31.6 & 1449.4 & 1800 & 2100 & " \\
\hline 7 & $5: 45$ & $11 \mathrm{hr} 54 \mathrm{~min}$ & 43.8 & 1493.2 & 1000 & 1100 & “. \\
\hline 8 & $5: 55$ & $12 \mathrm{hr} 4 \mathrm{~min}$ & 31.2 & 1524.4 & 1800 & 2100 & ' \\
\hline 9 & $6: 15$ & $12 \mathrm{hr} 24 \mathrm{~min}$ & 49.8 & 1574.2 & 1450 & 1150 & $"$ \\
\hline 10 & $6: 39$ & $12 \mathrm{hr} 48 \mathrm{~min}$ & 29.6 & 1603.8 & 1820 & $165 b$ & Murin \\
\hline 11 & $7: 00$ & $13 \mathrm{hr} 9 \mathrm{~min}$ & 51.6 & 1655.4 & 1450 & 1100 & " \\
\hline 12 & $7: 20$ & $13 \mathrm{he} 29 \mathrm{~min}$ & 32.2 & 1687.6 & 1850 & 1450 & $"$ \\
\hline 13 & $7: 40$ & $13 \mathrm{hr} 49 \mathrm{man}$ & 50.4 & 1738.0 & 1600 & 1250 & " \\
\hline 14 & $7: 55$ & $14 \mathrm{hr} 4 \mathrm{~min}$ & 30.2 & 1768.2 & 1800 & 1650 & 4 \\
\hline 15 & $8: 15$ & $14 \mathrm{hr} 24 \mathrm{~min}$ & 52.0 & 1820.2 & 1500 & 1250 & ". \\
\hline
\end{tabular}

WASTE TYPE AVERAGE CHARGING RATE_118.0 点( $\left.\frac{560.4}{4.75 \mathrm{hr}}\right)$ AVERAGE UPPER CHAMBER TEMP 1642.9 AVERACE LOWER CHAMBER TEMP 1596.7
ENGINEER - name_Jeannette Murin_; Blgnature TECINICIAN - name Jorna Faught/Terry Sourm a1gnature DATE $10 / 24 \mid 8]$ 
TABLE B.1. Incinerator Operating Conditions for Run 2 (Sheet 4 of 9)

\begin{tabular}{|c|c|c|c|c|c|c|c|}
\hline \multicolumn{8}{|c|}{ INCINERATOR OPERATING CONDITIONS } \\
\hline No. & $\begin{array}{c}\text { Time } \\
\left(100^{\prime} \text { s hrs }\right)\end{array}$ & $\begin{array}{c}\text { Length of } \\
\text { Operation (hrs) }\end{array}$ & $\begin{array}{l}\text { Wt. of Charge } \\
\text { (1ba) }\end{array}$ & $\begin{array}{l}\text { Total Wt } \\
\text { F1red (1bs) }\end{array}$ & $\begin{array}{l}\text { Lower Chamber } \\
\text { Temp (F) }\end{array}$ & $\begin{array}{l}\text { Upper Chamber } \\
\text { Temp (F) }\end{array}$ & $\begin{array}{c}\text { Entered } \\
\text { by }\end{array}$ \\
\hline 1 & $8: 35$ & $14 \mathrm{hr} 44 \mathrm{~min}$ & 30.8 & 1851.0 & 1800 & 1600 & Murin \\
\hline 2 & $8: 45$ & $14 \mathrm{hr} 54 \mathrm{~min}$ & $\begin{array}{ll}1 & 44.4 \\
\end{array}$ & 1895.4 & 1600 & 1300 & 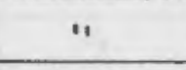 \\
\hline 3 & $9: 10$ & $15 \mathrm{hr} 19 \mathrm{~min}$ & $2 \quad 32.4$ & 1927.8 & 1750 & 1400 & $" 1$ \\
\hline 4 & $9: 30$ & $15 \mathrm{hr} 39 \mathrm{~min}$ & 148.0 & 1975.8 & $165 D$ & 1200 & $" 1$ \\
\hline 5 & $9: 50$ & $15 \mathrm{hr} 59 \mathrm{~min}$ & $2 \quad 30.8$ & 2006.6 & 2000 & 1500 & Sollivan \\
\hline 6 & $10: 10$ & $16 \mathrm{br} p 9 \mathrm{~min}$ & $\begin{array}{ll}1 & 49.8 \\
\end{array}$ & 2056.4 & 1600 & 1250 & 4 \\
\hline 7 & $10: 35$ & $16 \mathrm{hr} 44 \mathrm{~min}$ & 29.8 & 2086.2 & 1550 & 1450 & $M_{U R / n}$ \\
\hline 8 & $11: 02$ & $17 \mathrm{hr} 11 \mathrm{~min}$ & $1 \quad 53.0$ & 2139.2 & 1400 & 1100 & 1, \\
\hline 9 & $11: 20$ & $17 \mathrm{hr} 29 \mathrm{~min}$ & ${ }^{2} 30.0$ & 2169.2 & 1700 & 1600 & 1, \\
\hline 10 & $11: 30$ & $17 \mathrm{hr} 39 \mathrm{~min}$ & $1 \quad 54.0$ & 2233.2 & 1650 & 1350 & $1, F$ \\
\hline 11 & $12: 10$ & $18 \mathrm{he} 19 \mathrm{~min}$ & 23.2 & 2246,4 & 1600 & 1250 & ' \\
\hline 12 & $12: 30$ & $18 \mathrm{hr} 39 \mathrm{~min}$ & 1498 & 2296.2 & 1450 & 1100 & “ \\
\hline 13 & $12: 55$ & $19 \mathrm{hr} 4 \mathrm{men}$ & $3 \quad 436$ & 2339.8 & 1650 & 1400 & 11 \\
\hline 14 & $13 ; 15$ & $19 \mathrm{hr} 24 \mathrm{~min}$ & 55,2 & 2395,0 & 1500 & 1250 & " \\
\hline 15 & $13 ; 50$ & $19 \mathrm{hr} 59 \mathrm{~min}$ & 43.6 & 2438.6 & 1600 & 1400 & " \\
\hline
\end{tabular}

WASTE TYPE

AVERAGE CHARGING RATE

$\left.111.9 \stackrel{16}{\frac{b 87.6}{5.25 h r}}\right)$

AVERAGE UPPER CHAMBER TEAP

1343.3

AVERACE. LOWER CHAMBER TEMP
ENGINEER - name Jeannette Murin ; signature

TECHNICIAN - name Terry SULbivan; ; Bgature DATE $10 / 24 / 81$ John Fought* 
TABLE B.1. Incinerator Operating Conditions for Run 2 (Sheet 5 of 9)

\begin{tabular}{|c|c|c|c|c|c|c|c|}
\hline \multicolumn{8}{|c|}{ INCINERATOR OPERATING CONDITIONS } \\
\hline No. & $\begin{array}{c}\text { Time } \\
\left(100^{\prime} \mathrm{s} \text { hrs }\right)\end{array}$ & $\begin{array}{c}\text { Length of } \\
\text { operation (hrg) }\end{array}$ & $\begin{array}{l}\text { Wt. of Charge } \\
\text { (Ibs) }\end{array}$ & $\begin{array}{l}\text { Total Wt } \\
\text { F1 red (1bs) }\end{array}$ & $\begin{array}{l}\text { Lower Chamber } \\
\text { Temp (F) }\end{array}$ & $\begin{array}{l}\text { Upper Chamber } \\
\text { Temp (F) }\end{array}$ & $\begin{array}{c}\text { Entered } \\
\text { by }\end{array}$ \\
\hline 1 & $14 ; 10$ & $20 \mathrm{hr} 19 \mathrm{mia}$ & $\begin{array}{ll}2 & 29.4 \\
\end{array}$ & 2468.0 & 1650 & 1500 & MURLO \\
\hline 2 & $14: 35$ & $20 h r 44 \mathrm{men}$ & $\begin{array}{l}1 \\
\quad 54.4 \\
\end{array}$ & 2522.4 & 1450 & 1100 & 11 \\
\hline 3 & $15: 00$ & $21 \mathrm{hr} 9 \mathrm{~min}$ & $\begin{array}{ll}2 & 31.4 \\
1\end{array}$ & 2553.8 & 1550 & 1450 & is \\
\hline 4 & $15: 22$ & $21 \mathrm{hr} 31$ min & $\begin{array}{ll}1 & 45,8 \\
\end{array}$ & 2599.6 & 1400 & 1100 & 11 \\
\hline 5 & $15: 45$ & $21 \mathrm{hr} 54 \mathrm{~min}$ & 54.6 & 2654.2 & 1750 & 1550 & '" \\
\hline 6 & $16: 05$ & $22 \mathrm{hr} 14 \mathrm{~min}$ & 48.4 & 2702.6 & 1600 & $125 b$ & ، \\
\hline 7 & $16: 28$ & $22 \mathrm{hr} 37 \mathrm{~min}$ & $2 \quad 29.0$ & 2731.6 & 1700 & 1500 & If \\
\hline 8 & $16: 50$ & $22 \mathrm{hr} 59 \mathrm{~min}$ & 48.4 & 2780.0 & 1500 & 1100 & $"$ \\
\hline 9 & $17 ; 10$ & $23 \mathrm{hr} 19 \mathrm{~min}$ & 29.6 & 2809.6 & 1900 & 1550 & " \\
\hline 10 & $17: 35$ & $23 \mathrm{hr} 44 \mathrm{~min}$ & 4.5 .6 & 2855.2 & 1506 & 1250 & " \\
\hline 11 & 18:00 & $24 \mathrm{hr} 9 \mathrm{~min}$ & 29.4 & 2884.6 & 1650 & 1550 & " \\
\hline 12 & $18: 30$ & $24 \mathrm{hr} 39 \mathrm{~min}$ & 51.2 & 2935,8 & 1400 & 1800 & 1. \\
\hline 13 & $18 ; 50$ & $24 \mathrm{hr} 59 \mathrm{~min}$ & 30.0 & 2965.8 & 1600 & 1400 & " \\
\hline 14 & $19: \quad 10$ & $25 \mathrm{hr} 19 \mathrm{~min}$ & 46.8 & $3012 \cdot 6$ & 1450 & 1100 & " \\
\hline 1.5 & $19: 22$ & $25 \mathrm{hr} 31 \mathrm{~min}$ & $2 \quad 30.2$ & 3642.8 & 1740 & 1700 & " \\
\hline
\end{tabular}

HASTE TYPE

AVERAGE CHARGING RATE_110.5 is $\left(\frac{574.8}{5.2 \mathrm{hr}}\right)$ AVERAGE UPPER CHAMBER TEMP AVERAGE LOWER CHAMBER TEHP
1393.3 1589.3
ENGINEER - name Jeannelte Murin _; signature TECHNICIAN - name JoHN FauereT signature DATE $10 / 24 / 81$ 
TABLE B.1. Incinerator Operating Conditions for Run 2 (Sheet 6 of 9)

\begin{tabular}{|c|c|c|c|c|c|c|c|}
\hline \multicolumn{7}{|c|}{ INCINERATOR OPERATING CONDITIONS } & \multirow[b]{2}{*}{$\begin{array}{l}\text { Entered } \\
\text { by }\end{array}$} \\
\hline No. & $\begin{array}{c}\text { Time } \\
\left(100^{\prime} \mathrm{s} \mathrm{hrs}\right)\end{array}$ & $\begin{array}{c}\text { Length of } \\
\text { Operation (hrs) }\end{array}$ & $\begin{array}{l}\text { Wt. of Charge } \\
\text { (1bs) }\end{array}$ & $\begin{array}{l}\text { Total Wt } \\
\text { F1red (1ba) }\end{array}$ & $\begin{array}{l}\text { Lower Chamber } \\
\text { Temp (F) }\end{array}$ & $\begin{array}{l}\text { Upper Chamber } \\
\text { Temp (F) }\end{array}$ & \\
\hline 1 & $19: 45$ & $25 \mathrm{hr} 54 \mathrm{~min}$ & 137.6 & 3080.4 & 1600 & 1300 & MURIn \\
\hline 2 & $20: 00$ & $26 \mathrm{hr} 9 \mathrm{~min}$ & $3 \quad 60.8$ & 3141.2 & 1800 & 1700 & 11 \\
\hline 3 & $20: 20$ & $26 \mathrm{hr} 29 \mathrm{~min}$ & 41.4 & 3182.6 & 1550 & 1250 & 11 \\
\hline 4 & $20: 45$ & $26 \mathrm{hr}-54 \mathrm{~min}$ & 30.4 & 3213.0 & 1600 & 1450 & 11 \\
\hline$s$ & $21: 08$ & $27 \mathrm{hr} 17 \mathrm{~min}$ & 47.2 & 3260.2 & 1450 & 1100 & 1, \\
\hline 6 & $21: 30$ & $27 \mathrm{hr} 39 \mathrm{~min}$ & 32.4 & 3292.6 & 1600 & 1450 & 1 \\
\hline 7 & $21: 55$ & $28 \mathrm{hr} 4 \mathrm{~min}$ & 45.6 & 3338.2 & 1400 & 1100 & 4 \\
\hline 8 & $22: 15$ & $28 \mathrm{hr} 2 \mathrm{men}$ & 29.4 & 3367.6 & 1650 & 1450 & 1. \\
\hline 9 & $22: 40$ & $28 \mathrm{hr} \quad 49 \mathrm{~min}$ & 48.4 & 3416.0 & 1450 & 1150 & " \\
\hline 10 & $23: 00$ & $29 \mathrm{hr} 9 \mathrm{~min}$ & $\begin{array}{ll}3 & 5 \mathrm{ho} \\
\end{array}$ & 3472.0 & 1800 & 1450 & ". \\
\hline 11 & $23: 20$ & $29 \mathrm{hr} 29 \mathrm{~min}$ & 42.8 & 3514.8 & 1500 & $12 \pi 0$ & "; \\
\hline 12 & $23: 45$ & $29 \mathrm{hr} 54 \mathrm{~min}$ & $\begin{array}{ll}2 & 25.2 \\
\end{array}$ & 3540.0 & 1650 & 1450 & $\checkmark$ \\
\hline 13 & 0.08 & $30 \mathrm{hr} 17 \mathrm{~min}$ & 52.6 & 35926 & 1400 & 1200 & $"$ \\
\hline 14 & 0.30 & $30 \mathrm{hr} 39 \mathrm{~min}$ & 29.8 & 3622.4 & 1800 & 1750 & SulLiUnn ${ }^{+}$ \\
\hline is & $0: 50$ & $30 \mathrm{hr} 59 \mathrm{~min}$ & 47.6 & 3670.0 & 1506 & 1300 & " \\
\hline
\end{tabular}

WASTE TYPE

AVERAGE CHARGING RATE AVERAGE UPPER CHAMBER TEMP AVERAGE. LOWER CHAMBER TEMP
ENGINEER - name J. Murun/J Faught; signature TRCINICIAN - name ${ }^{*}$ T. SuLivan /E. Cox; algnature DATE $10 / 24,25 / 81$ 
TABLE B.1. Incinerator Operating Conditions for Run 2 (Sheet 7 of 9)

\begin{tabular}{|c|c|c|c|c|c|c|c|}
\hline \multicolumn{8}{|c|}{ INCINERATOR OPERATING CONDITIONS } \\
\hline No. & $\begin{array}{l}\text { Time } \\
\left(100^{\prime} \text { 's hrs }\right)\end{array}$ & $\begin{array}{c}\text { Length of } \\
\text { Operation (hra) }\end{array}$ & $\begin{array}{l}\text { Wt. of Charge } \\
(1 \mathrm{b \theta})\end{array}$ & $\begin{array}{l}\text { Total Wt } \\
\text { Fired (1bs) }\end{array}$ & $\begin{array}{l}\text { Lower Chamber } \\
\text { Temp (F) }\end{array}$ & $\begin{array}{l}\text { Upper Chamber } \\
\text { Temp (F) }\end{array}$ & $\begin{array}{c}\text { Entered } \\
\text { by }\end{array}$ \\
\hline 1 & $1: 22$ & $31 \mathrm{hr} 31 \mathrm{~min}$ & 31.4 & 3701.4 & 1500 & 1350 & SULIVAR \\
\hline 2 & $1: 52$ & $32 \mathrm{hr} / \mathrm{min}$ & 51.0 & 3752,4 & 1300 & 1106 & $\because$ \\
\hline 3 & $2: 10$ & $32 \mathrm{hr} 19 \mathrm{~min}$ & 30.2 & 3782.6 & 1800 & 1600 & $"$ \\
\hline 4 & $2: 30$ & $32 \mathrm{hr} 39 \mathrm{~min}$ & $1 \quad 478$ & 3830,4 & 1550 & 1200 & 4 \\
\hline 5 & $2: 49$ & $32 \mathrm{hr} 58 \mathrm{~mm}$ & 298 & 3860.2 & 1750 & 1600 & $\because$ \\
\hline 6 & $3: 09$ & $33 \mathrm{hr} \quad 18$ men & 42.8 & 39030 & 1600 & 1200 & " \\
\hline 7 & $3: 25$ & $33 \mathrm{hr} 34 \mathrm{~min}$ & 328 & 3935.8 & 1700 & $17 \infty$ & $"$ \\
\hline 8 & $3: 40$ & $33 \mathrm{hr} \quad 49 \mathrm{mon}$ & 476 & 3983.4 & 1550 & 1250 & 4 \\
\hline 9 & $4: 03$ & $34 \mathrm{hr} \quad 12 \mathrm{~min}$ & 54.8 & 40382 & 1600 & 1600 & $"$ \\
\hline 10 & $4 ; 20$ & $34 \mathrm{hr} 29 \mathrm{~min}$ & 47.0 & 4085.2 & 1700 & 1400 & “ \\
\hline 11 & 4:44 & $34 \mathrm{hr} 53 \mathrm{~mm}$ & 29.0 & $4114 \cdot 2$ & 1650 & 1500 & " \\
\hline 12 & $5 ; \infty$ & $35 \mathrm{hr} 9 \mathrm{~min}$ & 43.4 & 4157.6 & 1500 & 1300 & 4 \\
\hline 13 & $5: 15$ & $35 \mathrm{hr} 24 \mathrm{~min}$ & 46.4 & 4204.0 & 1800 & 1700 & " \\
\hline 14 & $5: 33$ & $35 \mathrm{hr} 42 \mathrm{~min}$ & 456 & 42496 & 1600 & 1300 & " \\
\hline 1.5 & $5: 51$ & $36 \mathrm{hr}$ & 228.4 & 4278,2 & 1800 & 1700 & $n$ \\
\hline
\end{tabular}

WASTE TYPE

AVERAGE CHARGING RATE_128.7点 $\left(\frac{576.8}{4.4833}\right)$

AVERAGE UPPER CHAMBER TEMP_ 1433.3 AVERAGE. LOHER CHAMBER TEMP 
TABLE B.1. Incinerator Operating Conditions for Run 2 (Sheet 8 of 9)

\begin{tabular}{|c|c|c|c|c|c|c|c|}
\hline \multicolumn{8}{|c|}{ INCINERATOR OPERATING CONDITIONS } \\
\hline No. & $\begin{array}{c}\text { Time } \\
\left(100^{\prime} \mathrm{s} \text { hrs }\right)\end{array}$ & $\begin{array}{c}\text { Length of } \\
\text { operation (hro) }\end{array}$ & $\begin{array}{l}\text { Wt. of Charge } \\
\text { (1be) }\end{array}$ & $\begin{array}{l}\text { Total Wt } \\
\text { Fired (1ba) }\end{array}$ & $\begin{array}{l}\text { Lower Chamber } \\
\text { Temp (F) }\end{array}$ & $\begin{array}{l}\text { Upper Chamber } \\
\text { Temp (F) }\end{array}$ & $\begin{array}{l}\text { Entered } \\
\text { by }\end{array}$ \\
\hline 1 & $6: 03$ & $36 \mathrm{hr} 12 \mathrm{~min}$ & 44.6 & 4322.8 & 1700 & 1400 & SULLIVAA \\
\hline 2 & $6: 52$ & $37 \mathrm{hr} / \mathrm{min}$ & 45.5 & 43683 & 1300 & 900 & 1. \\
\hline 3 & $7: 06$ & $37 \mathrm{hr} 15 \mathrm{~min}$ & 45.8 & 4414.1 & 1400 & 1100 & $"$ \\
\hline 4 & $7: 25$ & $37 \mathrm{hr} 34 \mathrm{~min}$ & 30.4 & $44: .5$ & 1700 & 1650 & "' \\
\hline 5 & $7: 37$ & $37 \mathrm{hr} 46 \mathrm{~min}$ & 54.0 & 4498.5 & 1600 & 1300 & 4 \\
\hline 6 & $8: 20$ & $38 \mathrm{hr} 29 \mathrm{~min}$ & 56.8 & 45553 & 1300 & 1000 & 4 \\
\hline 7 & $8: 45$ & $38 \mathrm{hr} 54 \mathrm{~min}$ & 50.0 & 4605.3 & 1400 & 1100 & " \\
\hline 8 & $9: 15$ & $39 \mathrm{hr} 24 \mathrm{~mm}$ & $2 \quad 29.6$ & 4634.9 & 1400 & 1300 & $"$ \\
\hline 9 & $9: 35$ & $39 \mathrm{hr} 44 \mathrm{~min}$ & 49.8 & 4684.7 & 1300 & 1100 & MuRin \\
\hline 10 & $10: 00$ & Whr 9 min & 29.0 & 47137 & 1500 & 1500 & $t_{1}$ \\
\hline 11 & $10: 25$ & $40 \mathrm{hr} 34 \mathrm{~min}$ & 39.8 & 4753.5 & 1300 & 1100 & 11 \\
\hline 12 & $10: 45$ & $40 \mathrm{hr} 54 \mathrm{~min}$ & 36.6 & 47901 & 1.50 & 1400 & " \\
\hline 13 & $11: 10$ & $41 \mathrm{hr} 19 \mathrm{~min}$ & 50.8 & 4840.9 & 1450 & 1150 & $\because$ \\
\hline 14 & $11: 30$ & $41 \mathrm{hr} 39 \mathrm{sm}$ & 61.2 & 49021 & 1650 & 1550 & 1 \\
\hline 15. & $12: 00$ & $42 \mathrm{hr} 9 \mathrm{~min}$ & 37.8 & 4939.9 & 1450 & 1150 & " \\
\hline
\end{tabular}

WASTE TYPE

AVERAGE CHARGING RATE__ $103.7 \frac{\mathrm{m}}{\mathrm{m}}\left(\begin{array}{l}617.1 \\ 5.95\end{array}\right)$

AVERAGE UPPER CHAMBER TEMP

AVERAGE. LOWER CHAMBER TEMP
1246.7

1466.7
ENGINEER - name I Murin *; signature TECINICIAN - name I. Sellivan/E cox; signature DATE $10 / 25 / 81$ 
TABLE B.1. Incinerator Operating Conditions for Run 2 (Sheet 9 of 9)

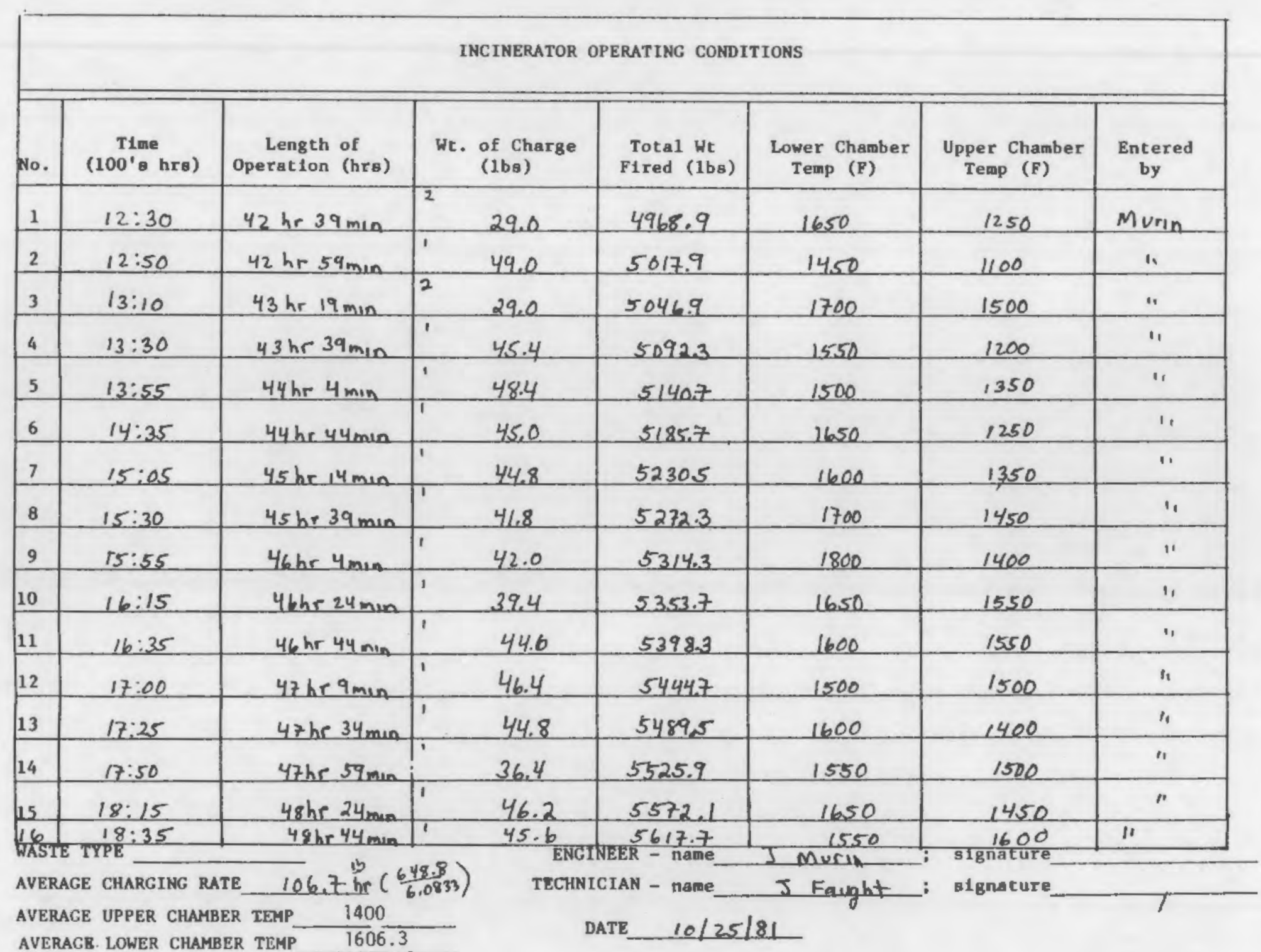




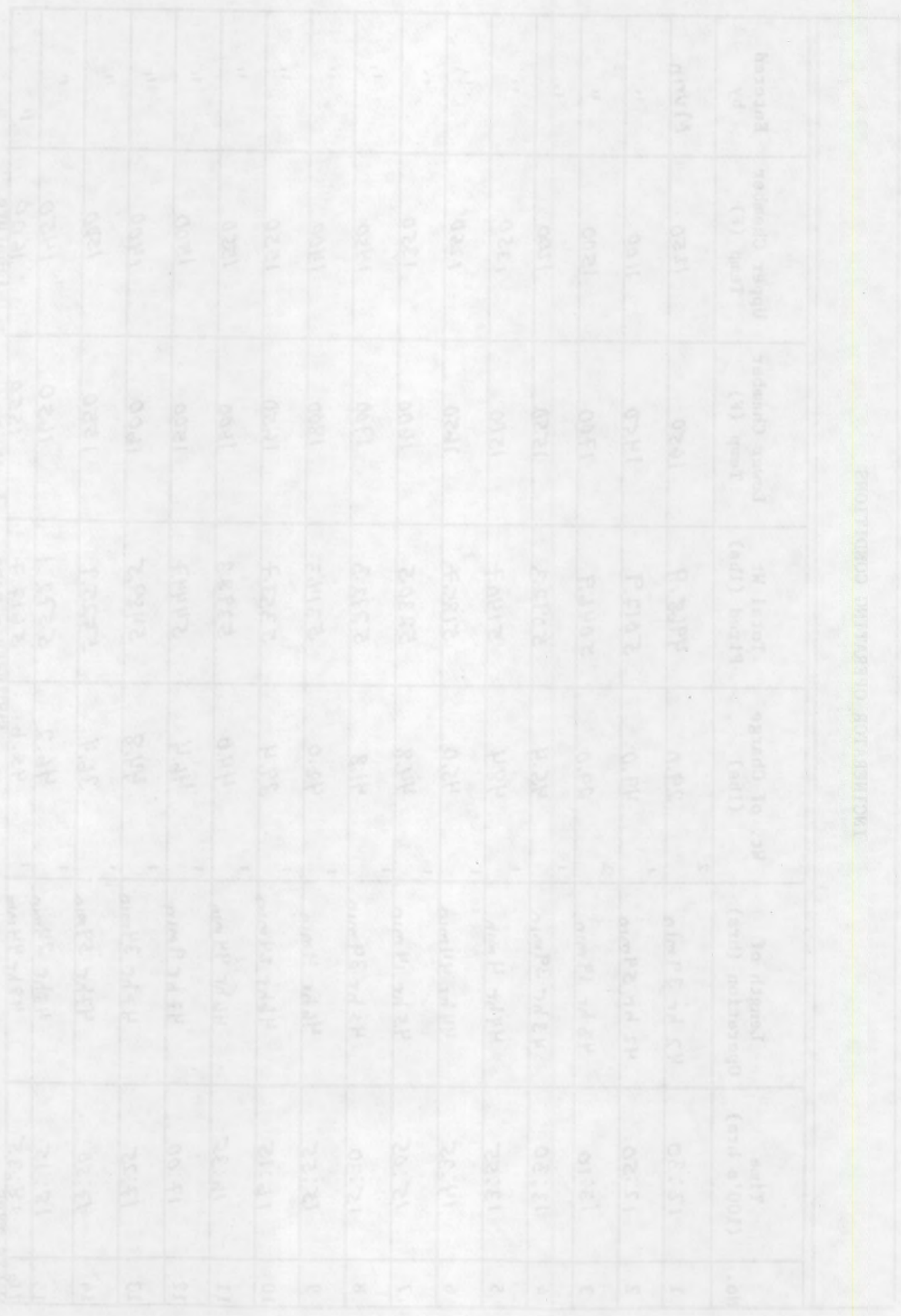


APPENDIX C

MASS SPECTROMETRY OF GAS COMPONENTS OF ASHES 


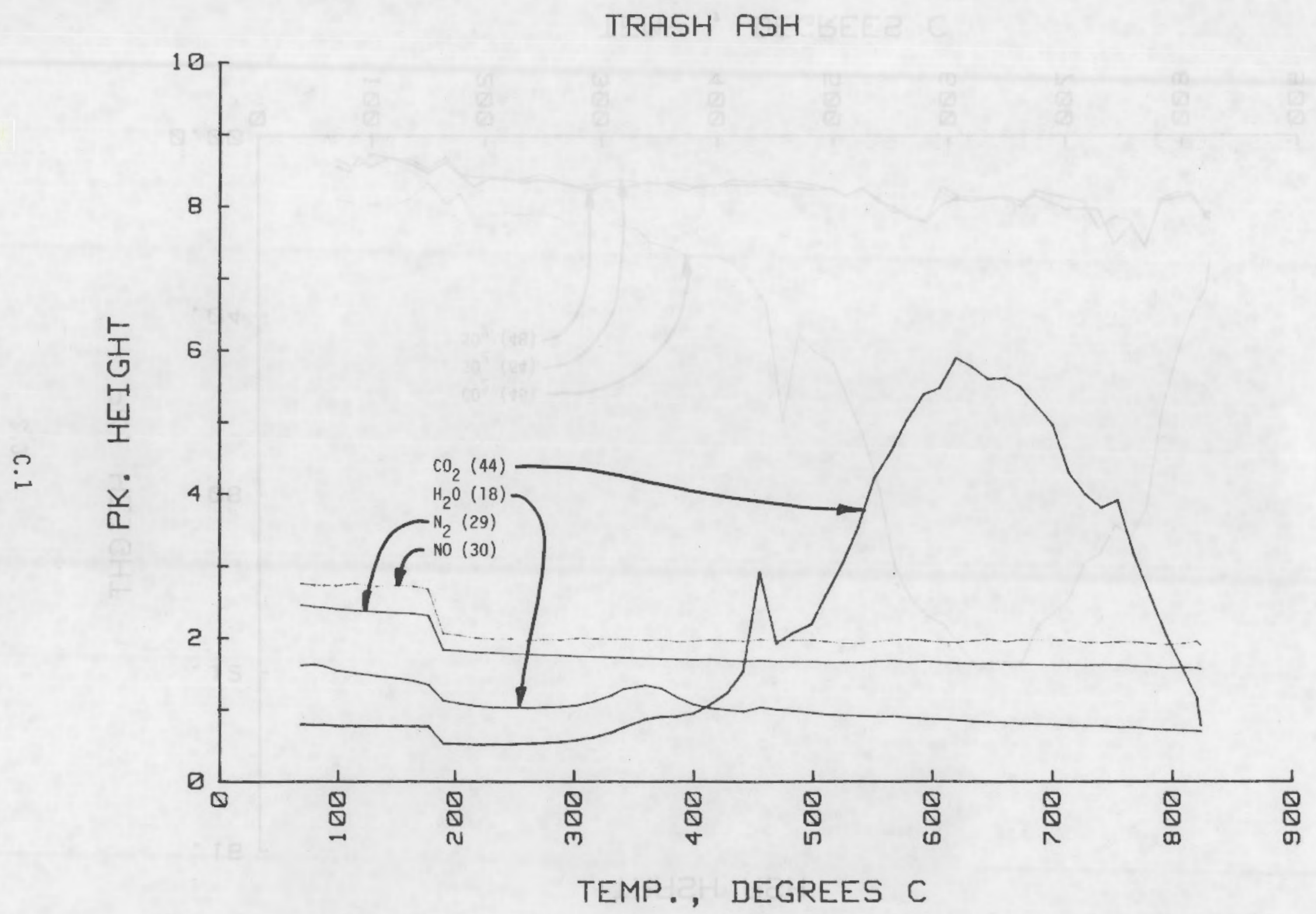

FIGURE C.1. Trash Ash Mass Spectrometry for $\mathrm{CO}_{2}(44), \mathrm{H}_{2} \mathrm{O}(18), \mathrm{N}_{2}(29)$ and $\mathrm{NO}(30)$ 
TRASH ASH

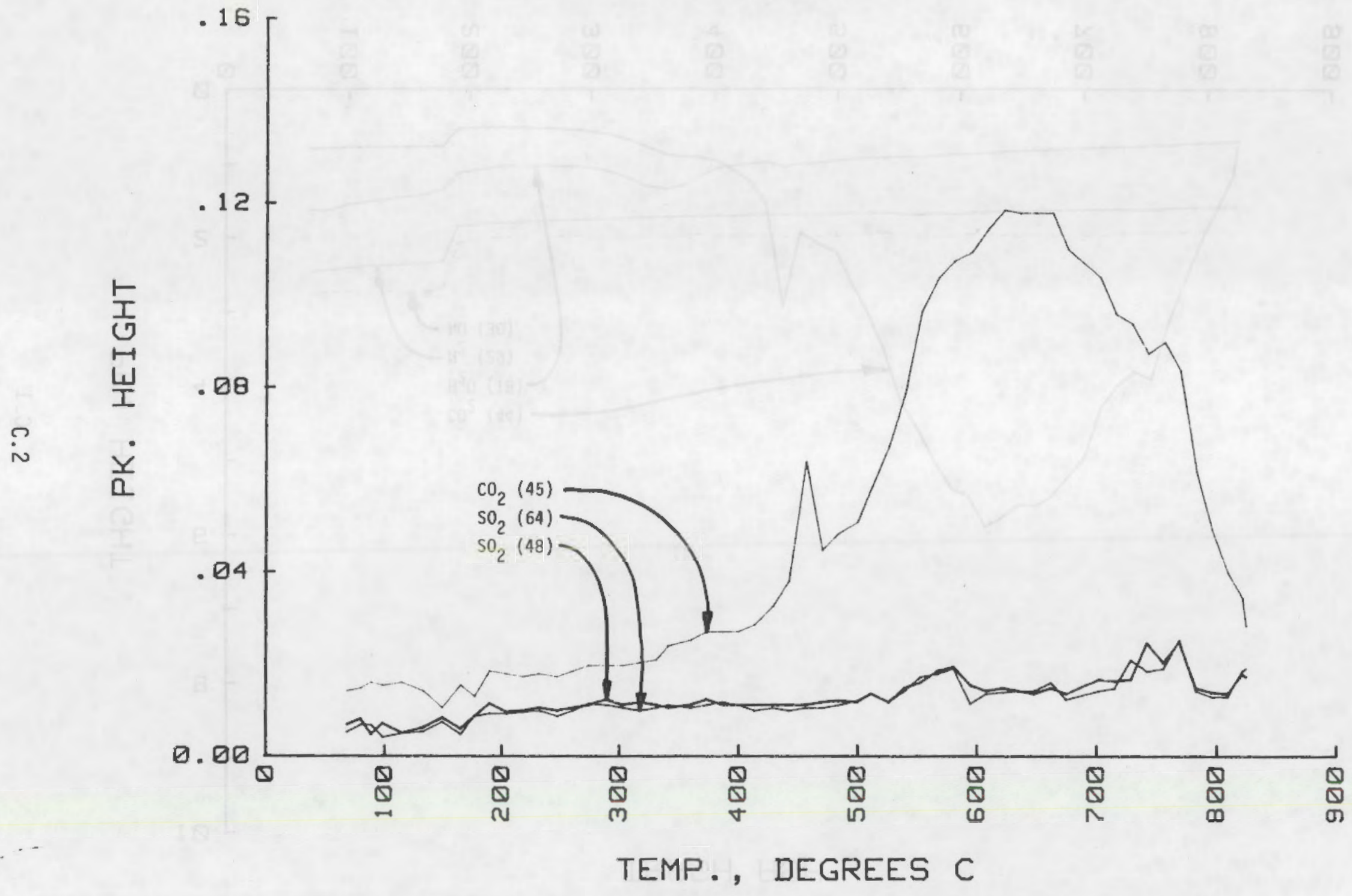

FIGURE C.2. Trash Ash Mass Spectrometry for $\mathrm{CO}_{2}(45), \mathrm{SO}_{2}(64)$, and $\mathrm{SO}_{2}(48)$ 


\section{TRASH ASH}

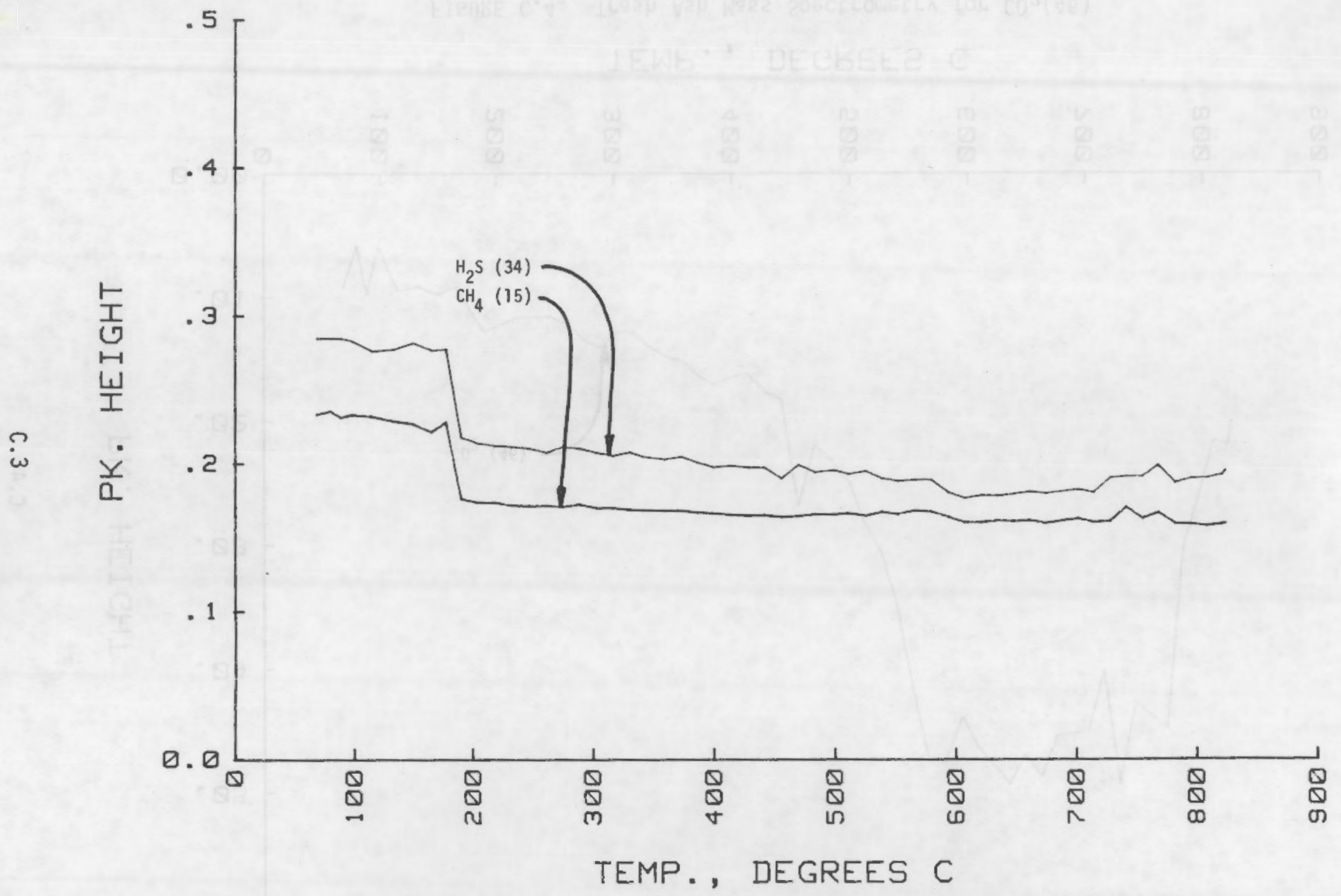

FIGURE C.3. Trash Ash Mass Spectrometry for $\mathrm{H}_{2} \mathrm{~S}(34)$, and $\mathrm{CH}_{4}(15)$ 
TRASH ASH

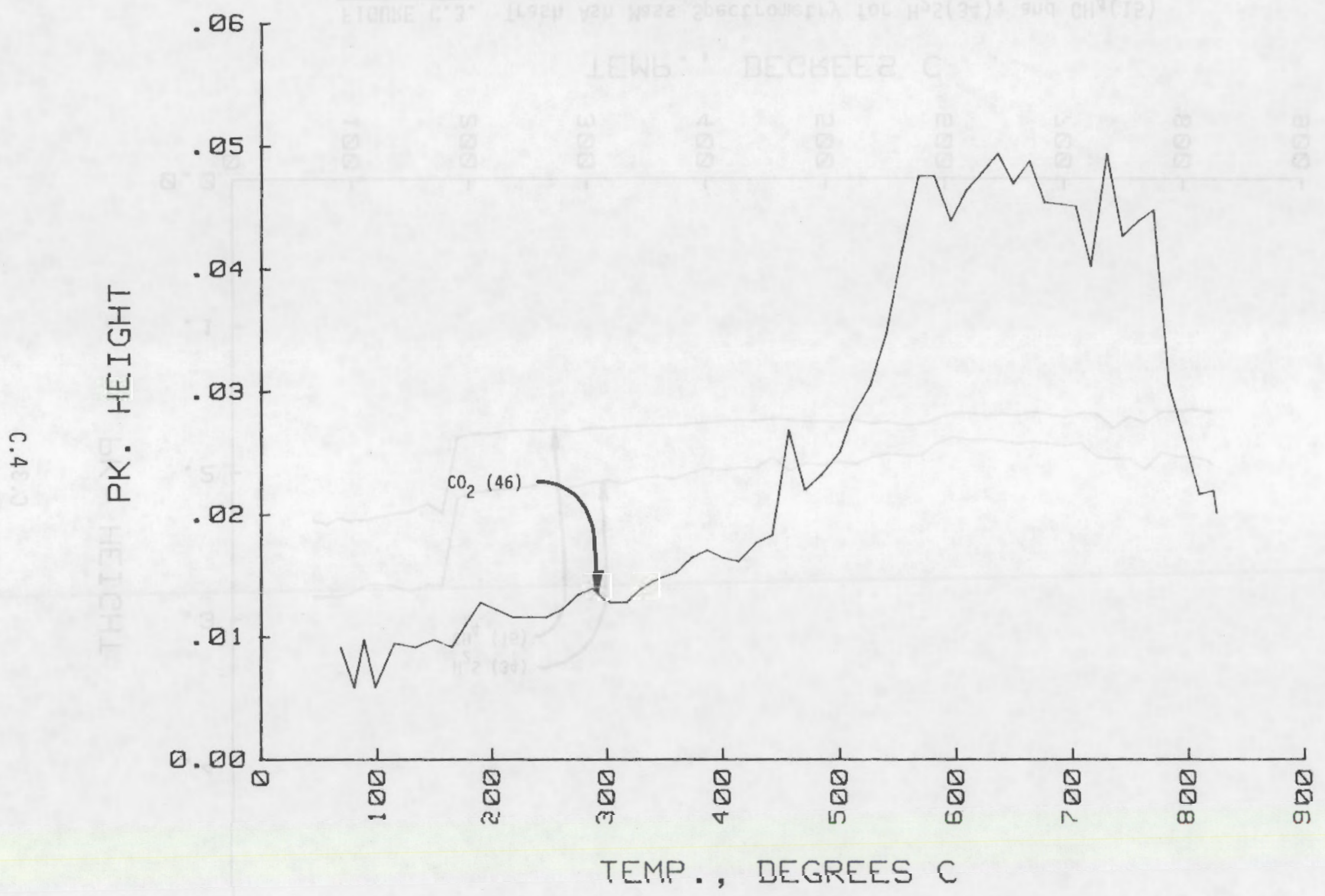

FIGURE C.4. Trash Ash Mass Spectrometry for $\mathrm{CO}_{2}(46)$ 
TRASH ASH

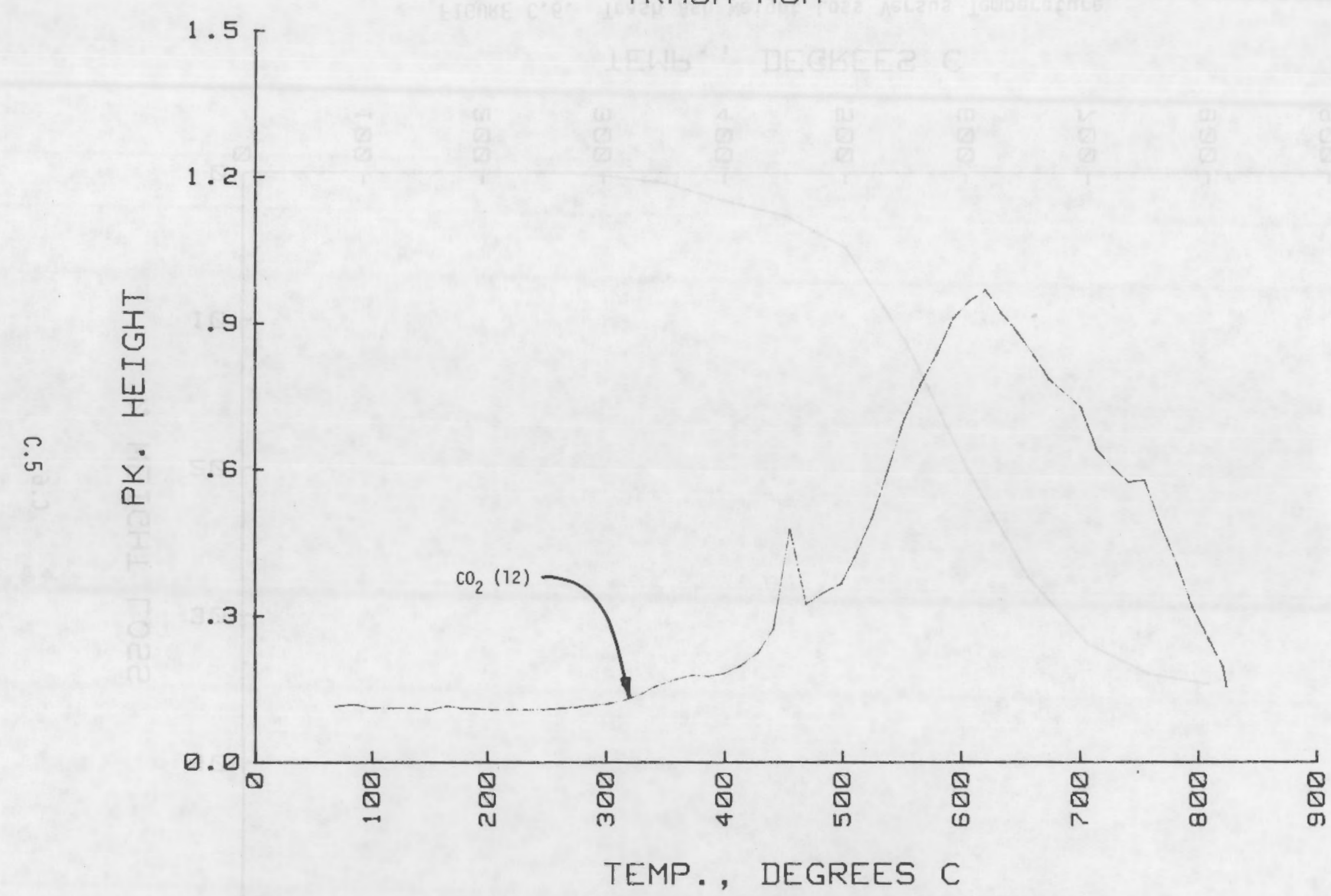

FIGURE C.5. Trash Ash Mass Spectrometry for $\mathrm{CO}_{2}(12)$ 
TRASH ASH

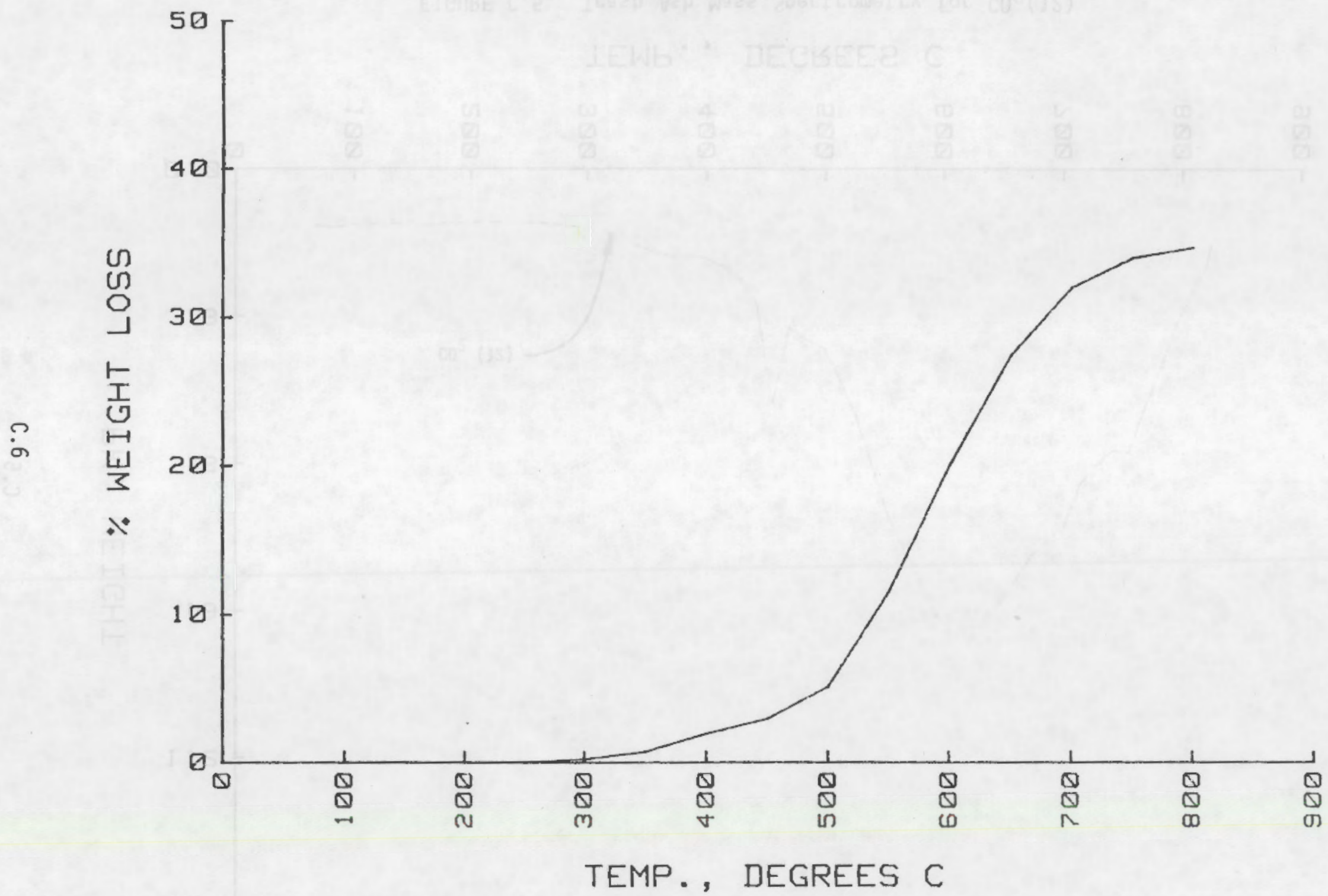

FIGURE C.6. Trash Ash Weight Loss Versus Temperature 


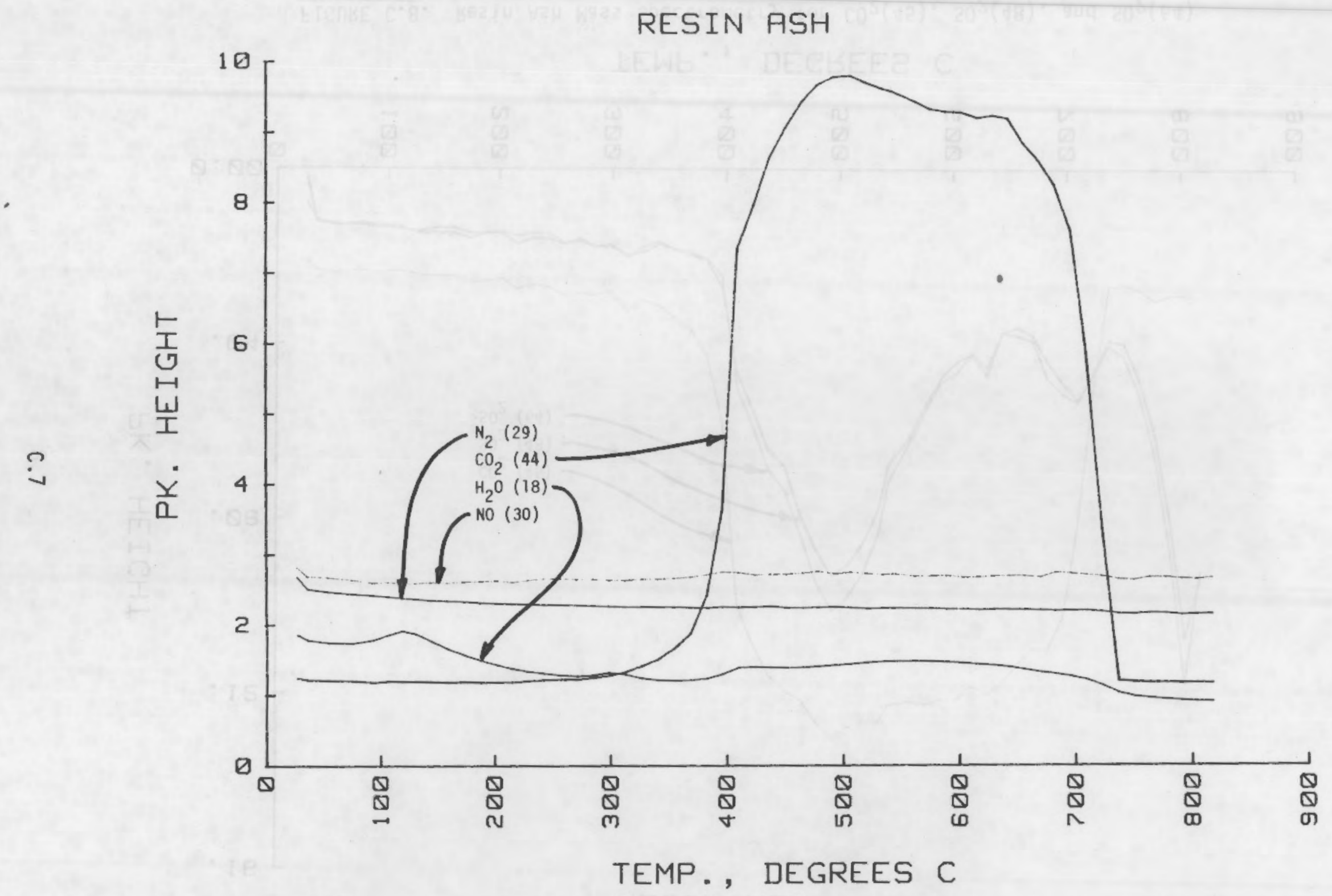

FIGURE C.7. Resin Ash Mass Spectrometry for $\mathrm{N}_{2}(29), \mathrm{CO}_{2}(44), \mathrm{H}_{2} \mathrm{O}(18)$ and $\mathrm{NO}(30)$ 


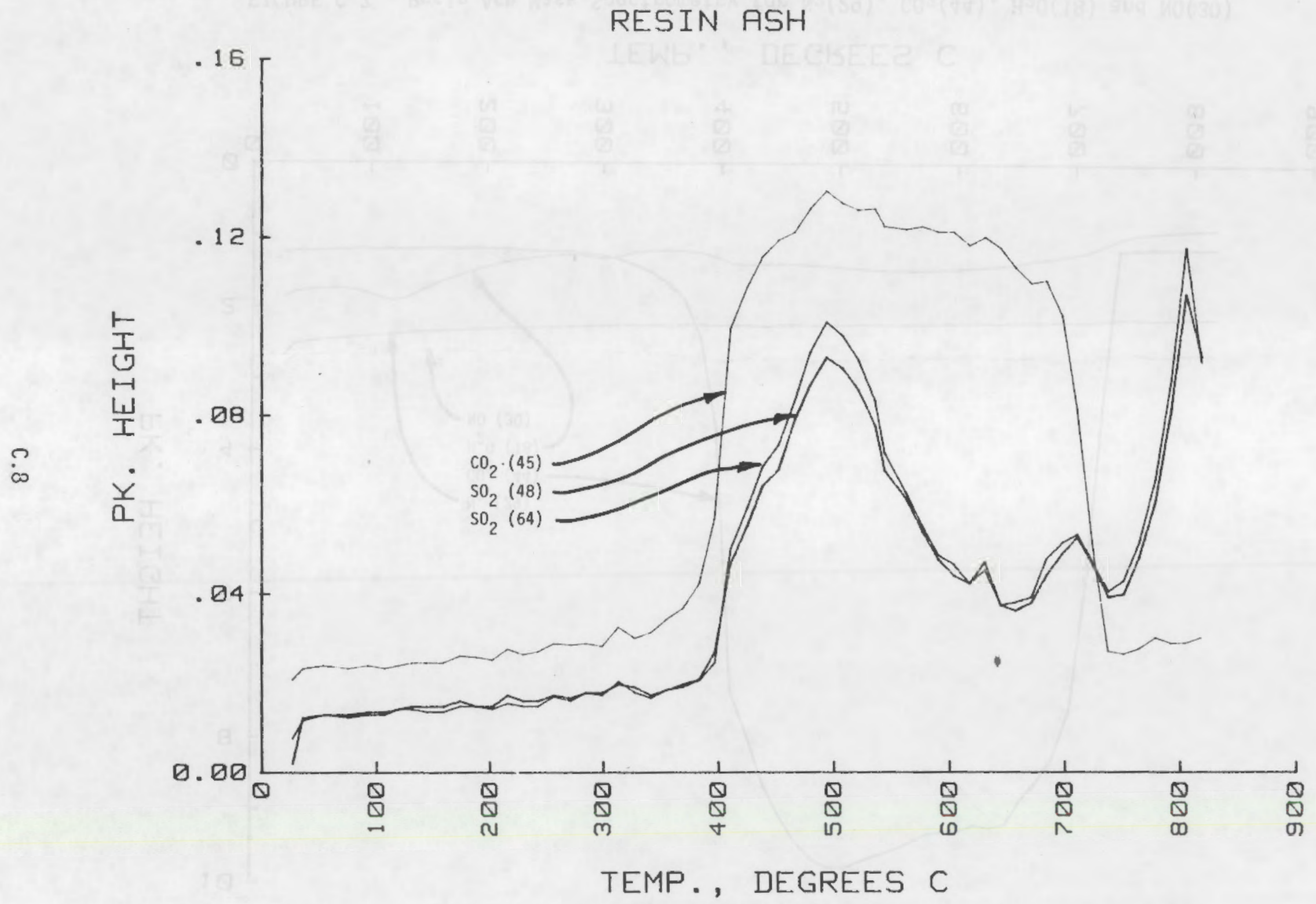

FIGURE C.8. Resin Ash Mass Spectrometry for $\mathrm{CO}_{2}(45), \mathrm{SO}_{2}(48)$, and $\mathrm{SO}_{2}(64)$ 


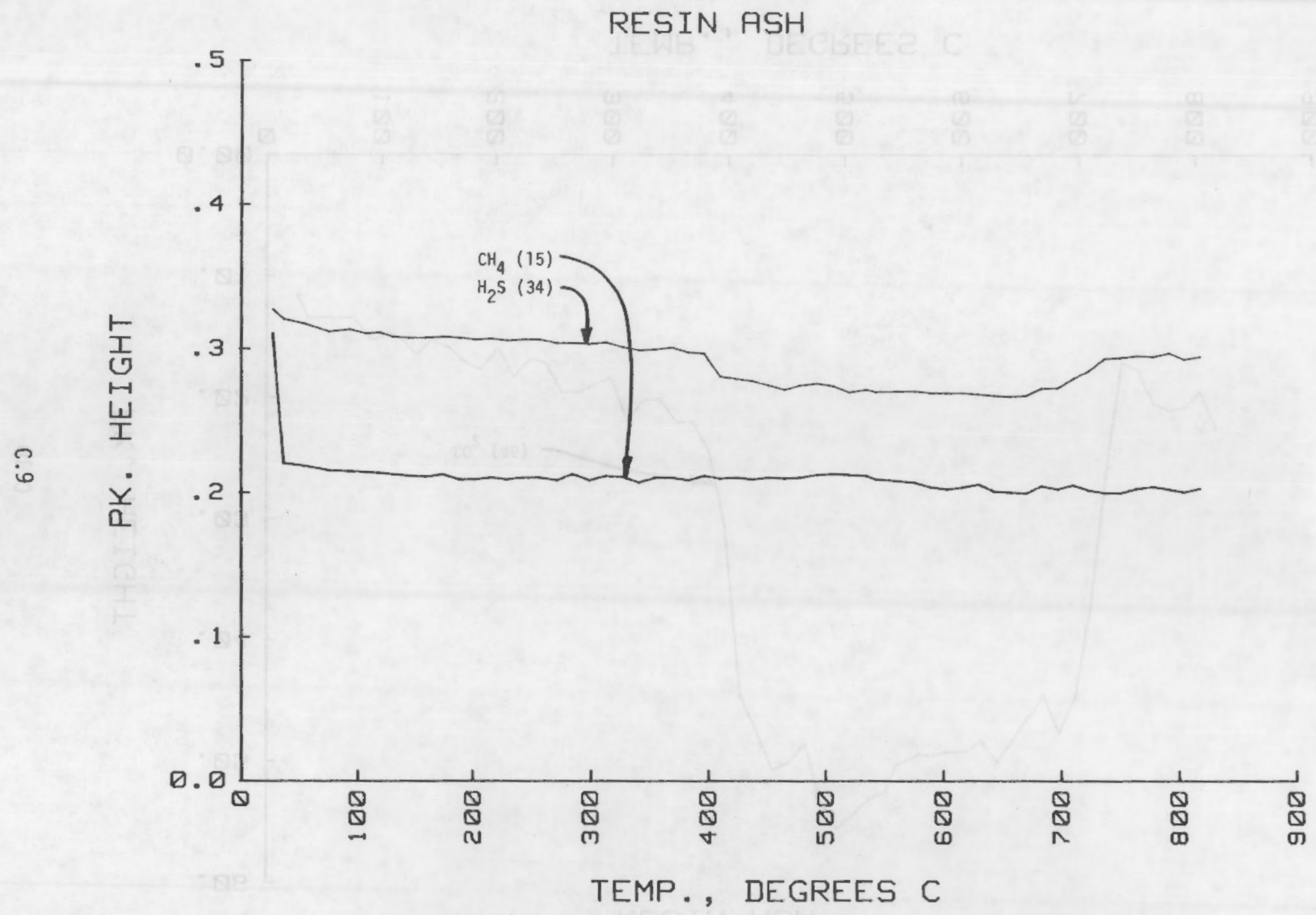

FIGURE C.9. Resin Ash Mass Spectrometry for $\mathrm{CH}_{4}(15)$, and $\mathrm{H}_{2} \mathrm{~S}(34)$ 


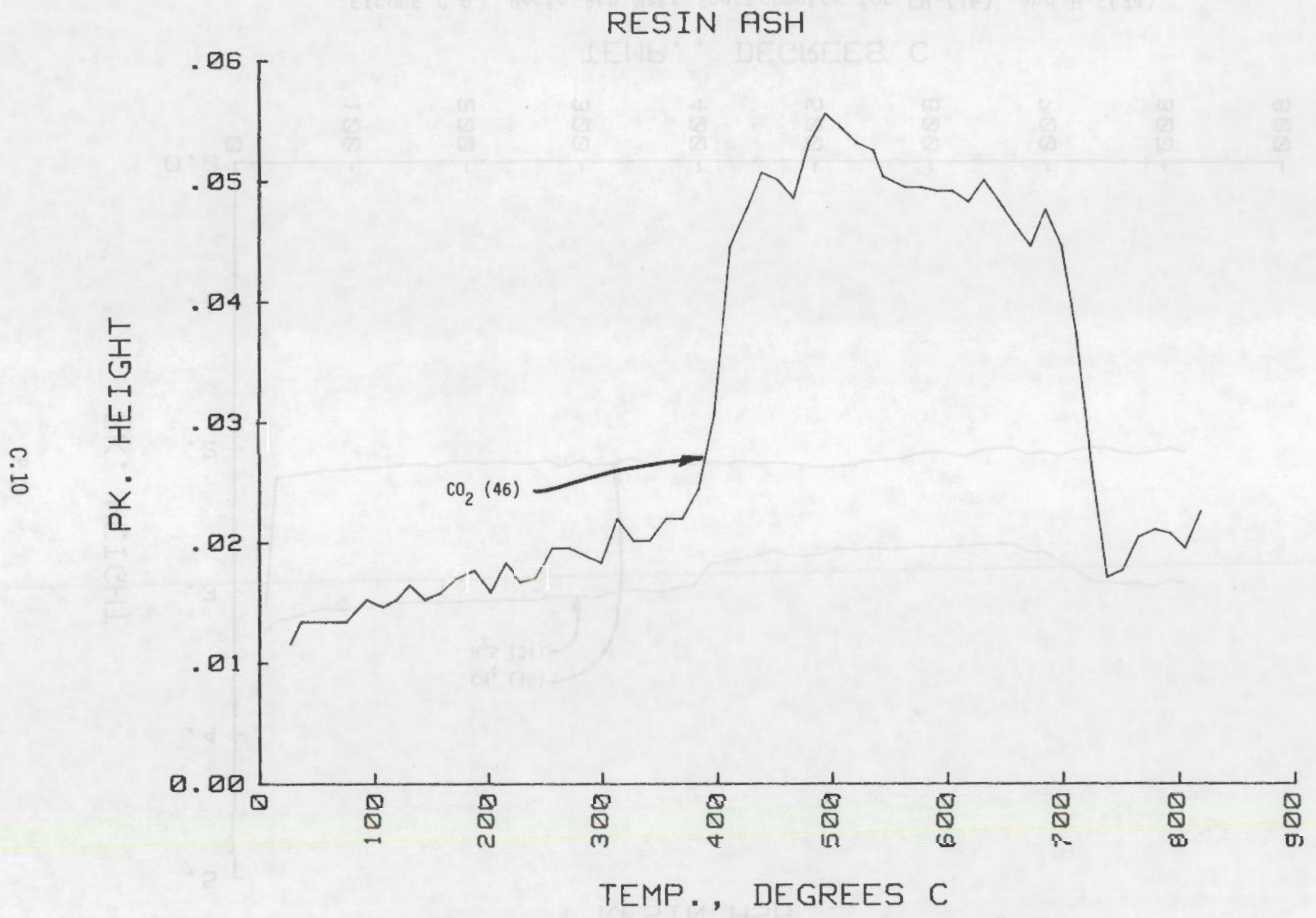

FIGURE C.10. Resin Ash Mass Spectrometry for $\mathrm{CO}_{2}(46)$ 


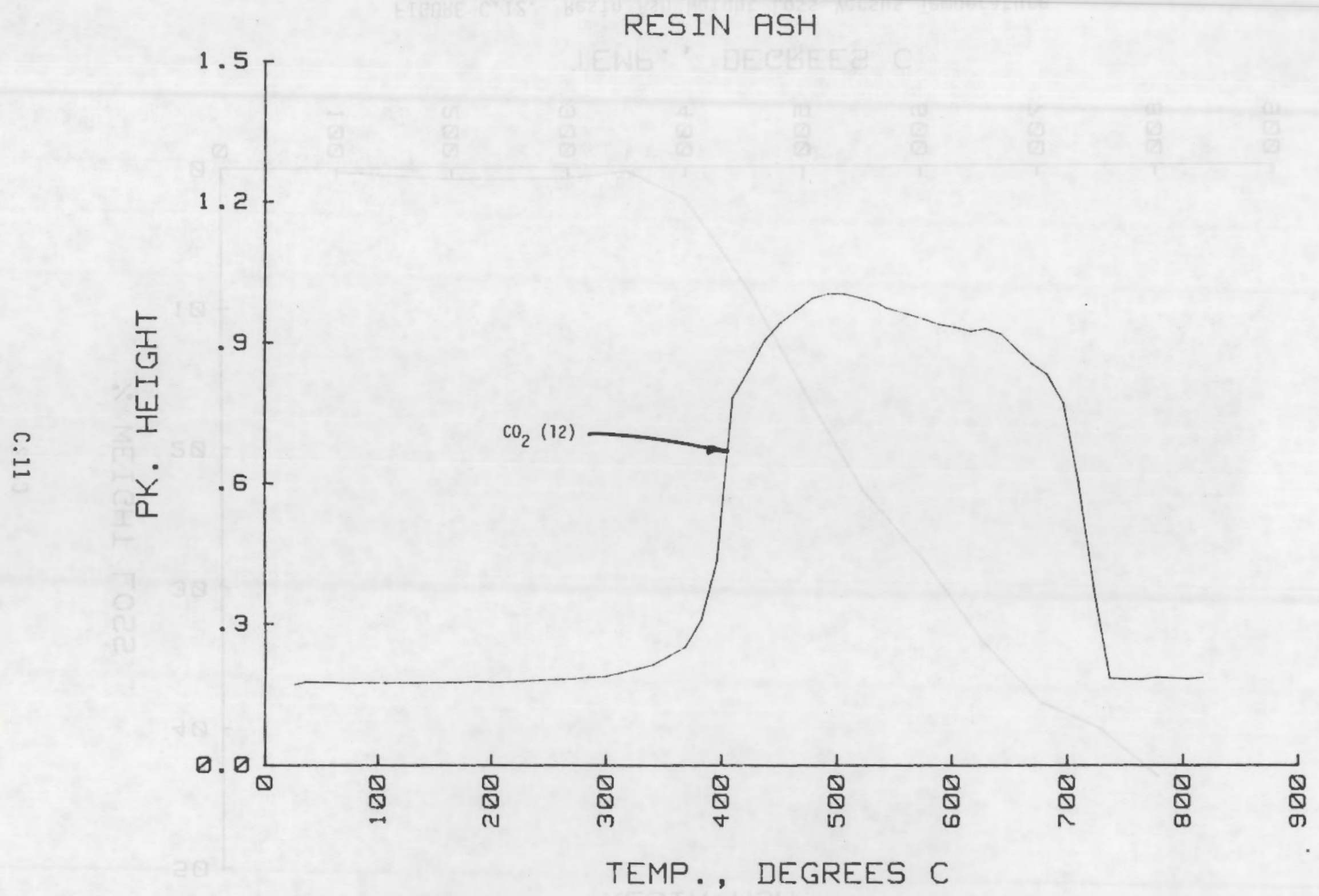

FIGURE C.11. Resin Ash Mass Spectrometry for $\mathrm{CO}_{2}(12)$ 


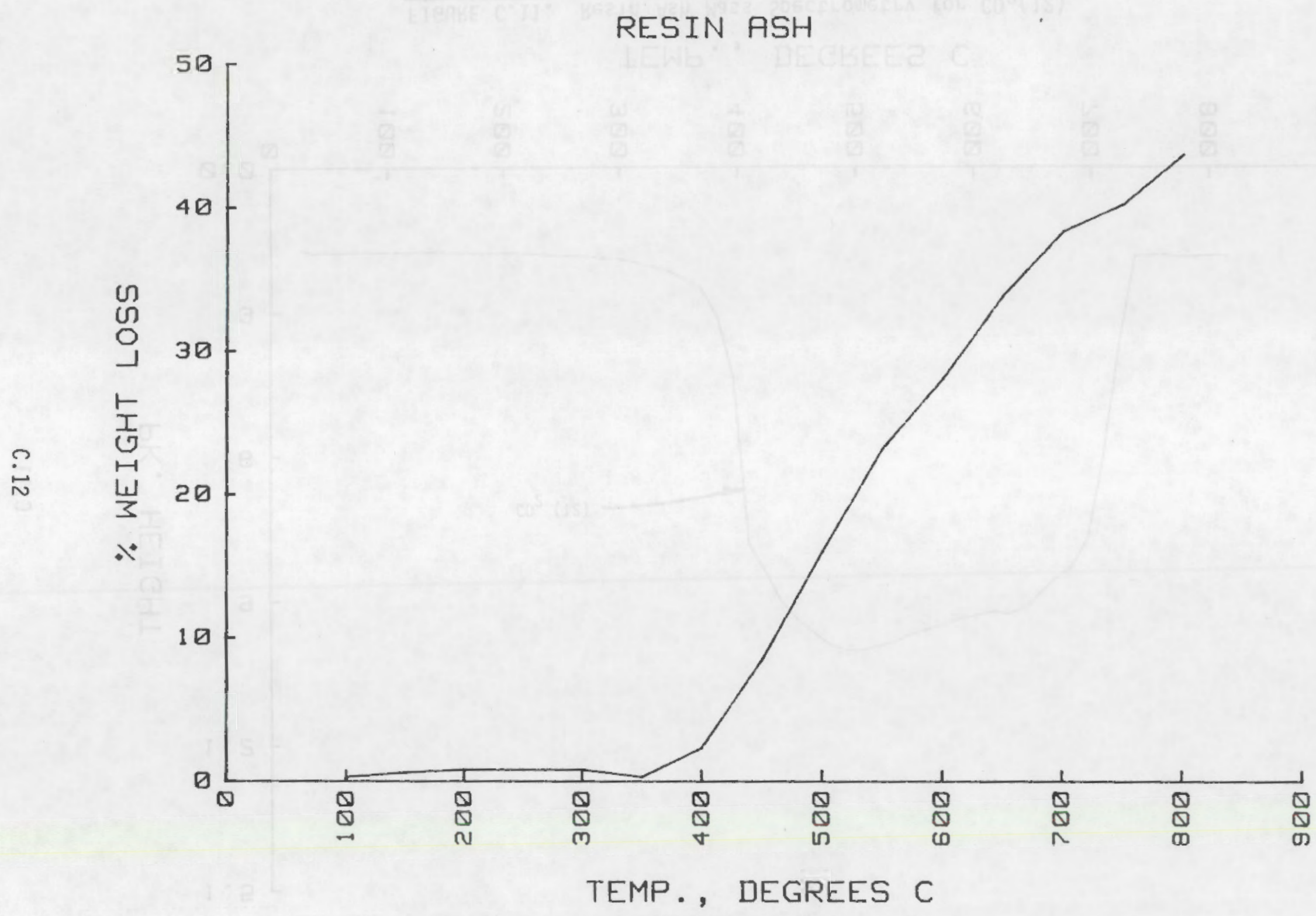

FIGURE C.12. Resin Ash weight Loss Versus Temperature 


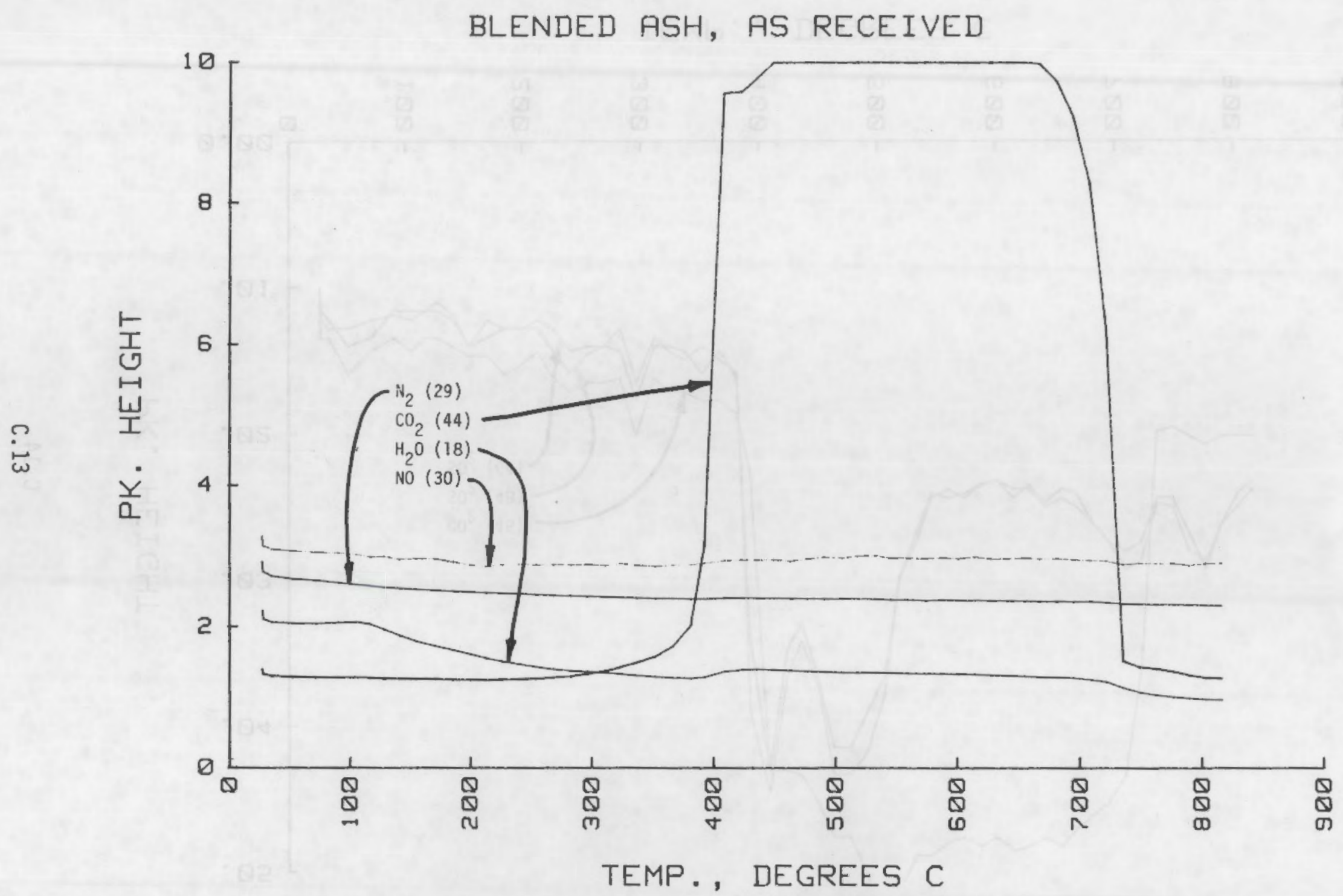

FIGURE C.13. Blended Ash Spectrometry for $\mathrm{N}_{2}(29), \mathrm{CO}_{2}(44), \mathrm{H}_{2} \mathrm{O}(18)$ and $\mathrm{NO}(30)$ 


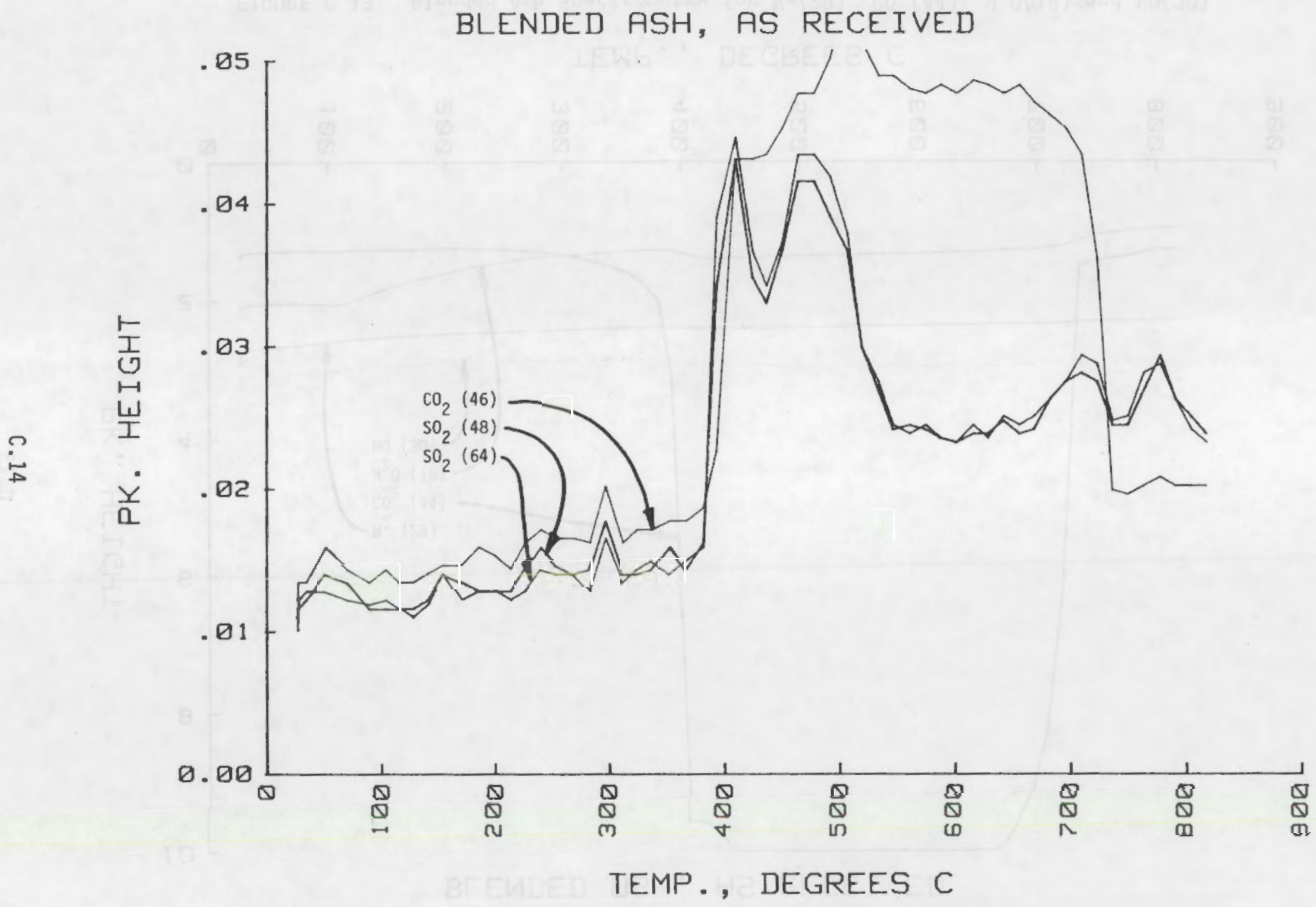

FIGURE C.14. Blended Ash Mass Spectrometry for $\mathrm{CO}_{2}(46), \mathrm{SO}_{2}(48)$, and $\mathrm{SO}_{2}(64)$ 


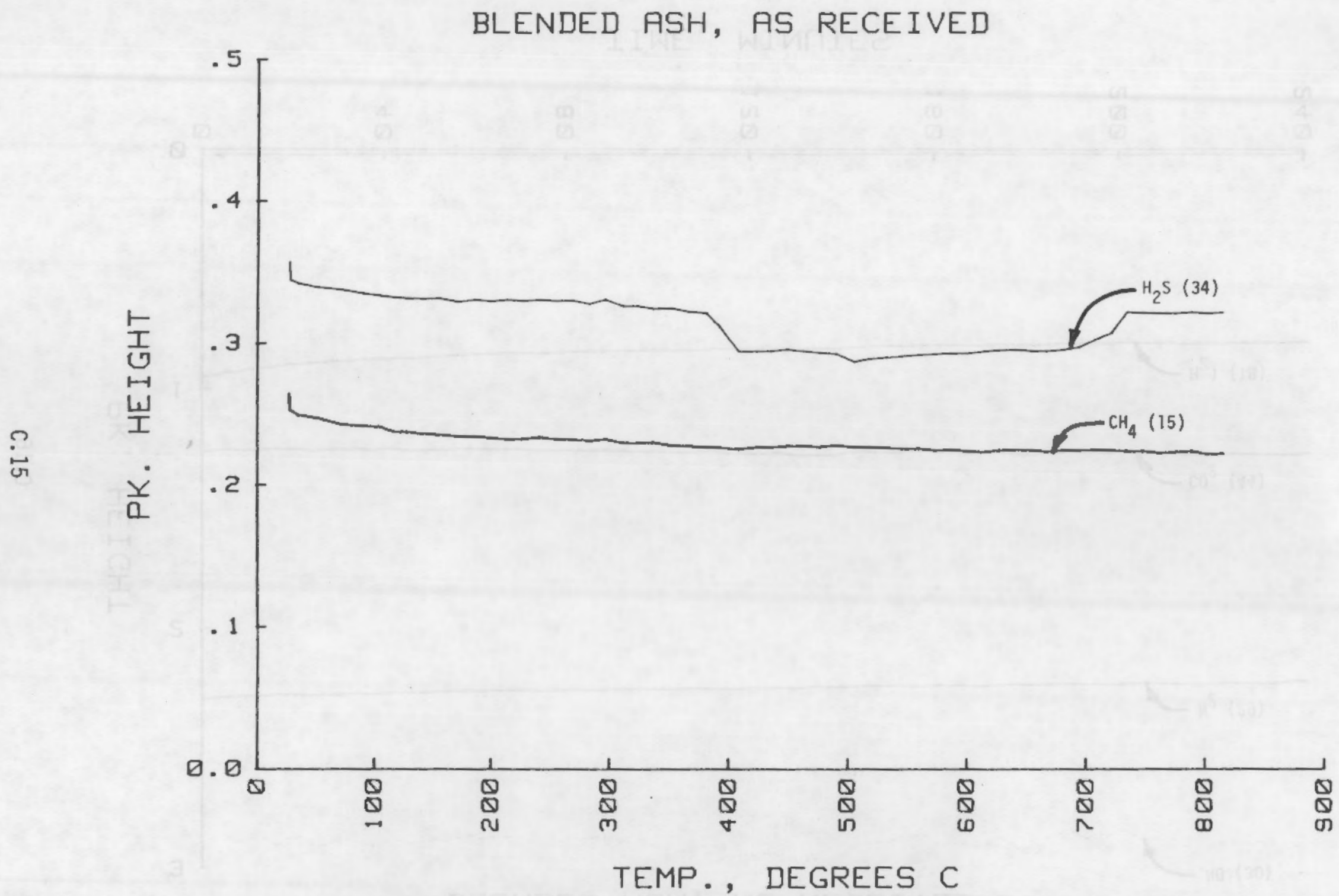

FIGURE C.15. Blended Ash Mass Spectrometry for $\mathrm{H}_{2} \mathrm{~S}(34)$ and $\mathrm{CH}_{4}(15)$ 


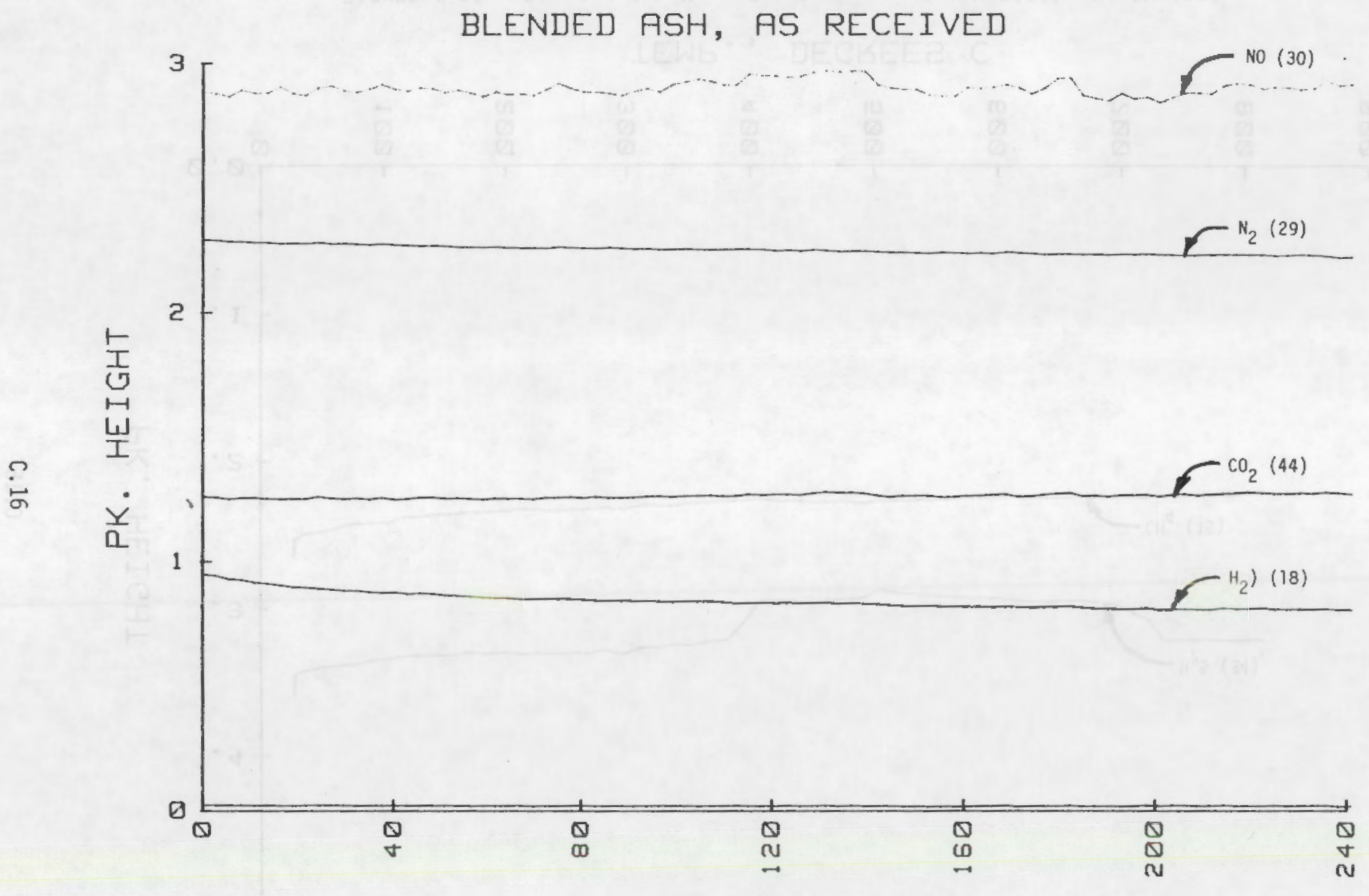

TIME, MINUTES

FIGURE C.16. Blended Ash Mass Spectrometry for $\mathrm{NO}(30), \mathrm{N}_{2}(29), \mathrm{CO}_{2}(44)$, and $\mathrm{H}_{2} \mathrm{O}(18)$ 


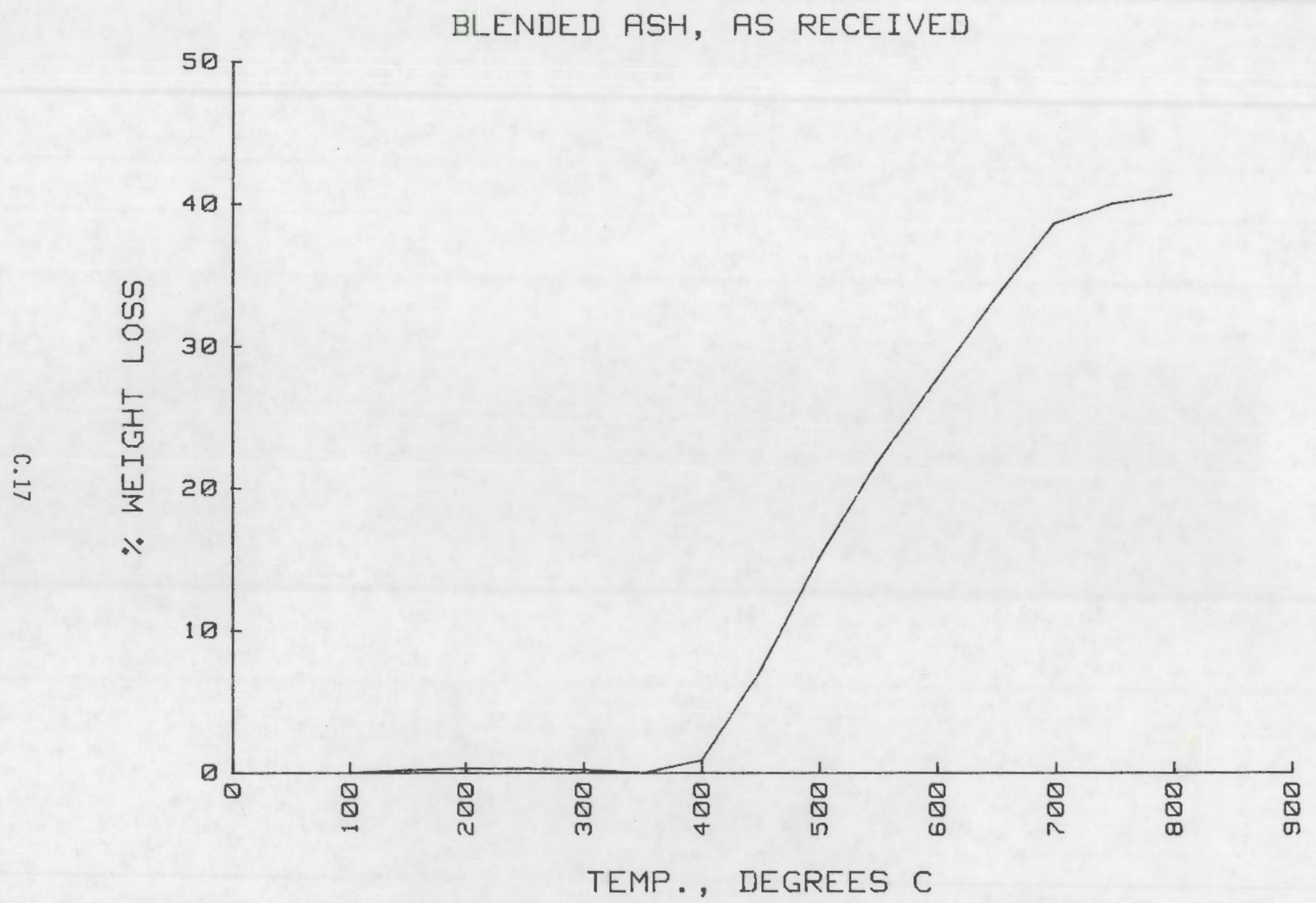

FIGURE C.17. Blended Ash Weight Loss Versus Temperature 

NUREG/CR-3087

PNL -4563

$\mathrm{RW}$

DISTRIBUTION

No. of

Copies

OFFSITE

Division of Technical

Information and Document Control

U.S. Nuclear Regulatory Commission

Washington, D.C. 20555

K. S. Kim

Division of Health, Siting, and Waste Management

Office of Nuclear Regulatory Research

U.S. Nuclear Regulatory Commission

Washington, DC 20555

Director, Division of Waste Management

Office of Nuclear Material Safety and Safeguards

U.S. Nuclear Regulatory Commission

Washington, DC 20555

Document Control Center

Office of Nuclear Material

Safety and Safeguards

U.S. Nuclear Regulatory Commission

washington, DC 20555

Larry Larson

Trojan Nuclear Power Plant

Rainier, OR 97048

Rich Abrams

Koch Process Systems

20 Walkup Drive

Westborough, MA 01581
No of

Copies

William Klein

Waste Chem

663 E. Crescent Avenue

Ramsey, NJ 07446

Steve Simpson

Associated Technologies, Inc.

222 South Church Street

Charlotte, NC 28202

E. I. Du Pont de Nemours \& Co. Savannah River Laboratory

Aiken, SC 29801

ATTN: George Becker Jack Crandall

Richard Reynolds

Bechtel Power Corporation

P.0. Box 3965

San Francisco, CA 94119

Bruce Rising

Battelle Columbus Laboratories

505 King Street

Columbus, $\mathrm{OH} 43201$

Nuclear Waste Management \&

Fuel Cycle Programs

NE 30 , GTN

Washington, DC 20545

ATTN: R. D. Walton

T. Chee

Los Alamos National Laboratory

P.0 Box 1663

Los Alamos, NM 08745

ATTN: Ralph Koenig

Leon Borduin

Brookhaven National Laboratory

Upton, Long Island, NY 11973

ATTN: Peter Colombo

Karl Swyler 
No. of

Copies

R. M. Waters

C-E Power Systems

Combustion Engineering, Inc. 1000 Prospect Hill Road

Windsor, CI 06095

J. W. Mandler

EG\&G Idaho

P.0. Box 1625

Idaho Falls, ID 83415

Rockwell Hanford Operations

M. J. Schliebe (5)
No. of

Copies

ONSITE

Pacific Northwest Laboratory

W. F. Bonner

R. W. Perkins

R. 0. Lokken (5)

R. P. Turcotte

J. L. McElroy

R. E. Nightingale

J. H. Jarrett

J. H. Westik, Jr.

R. L. Treat (10)

S. E. King

J. M. Latkovich

D. E. Larson

Publishing Coordination (VG) (2)

Technical Information (5) 


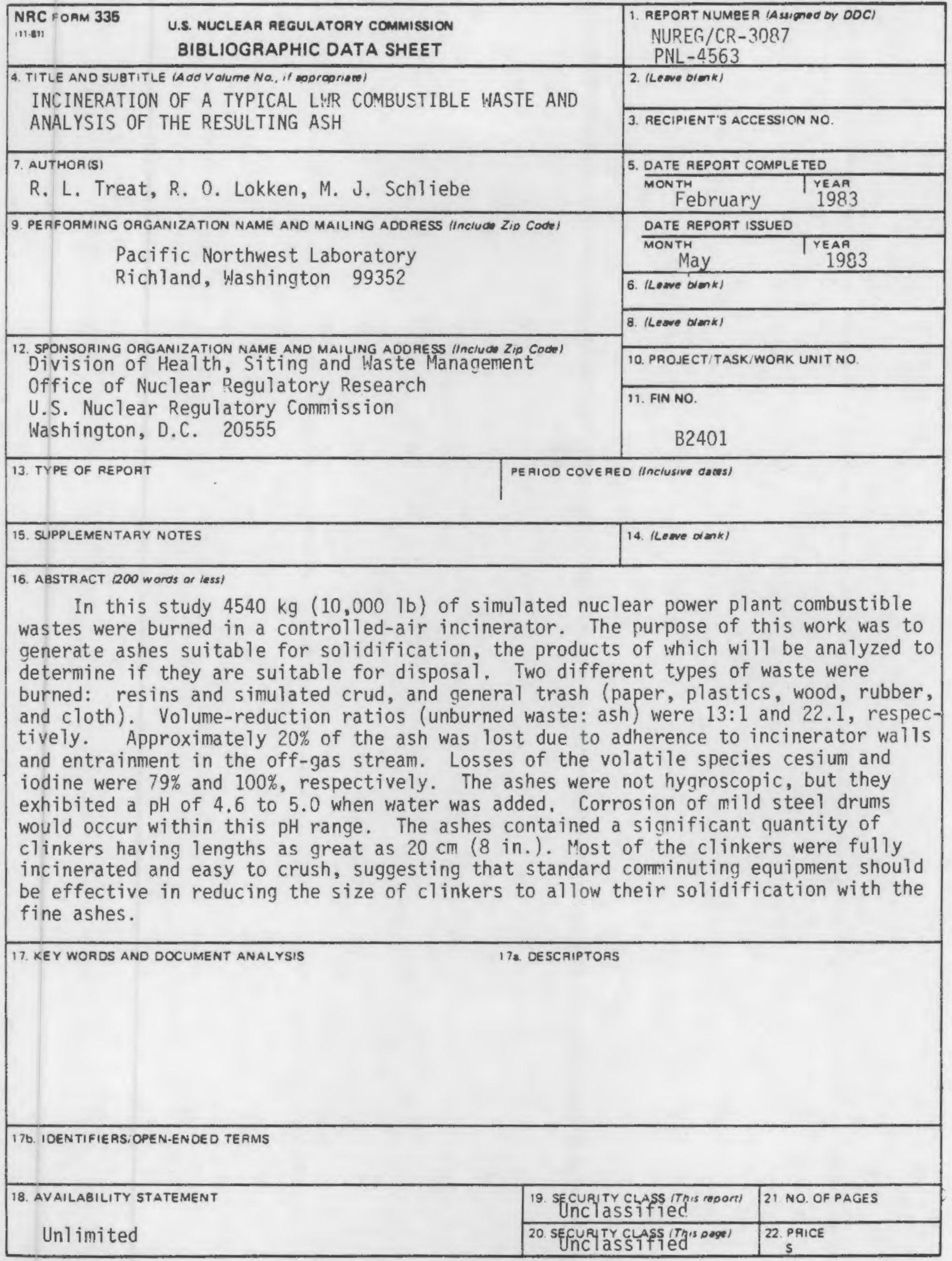




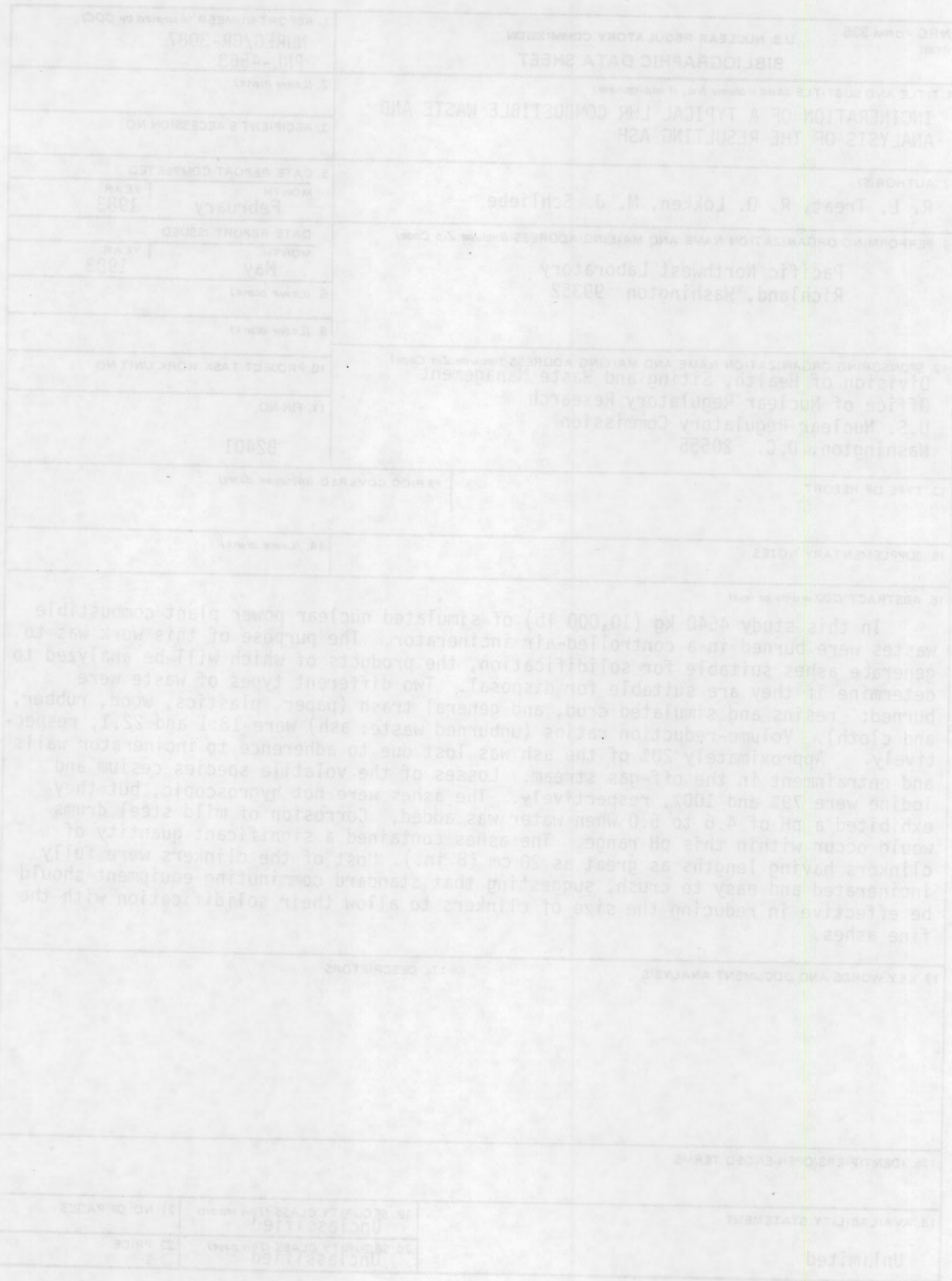

